\title{
Global observations and modeling of atmosphere-surface exchange of elemental mercury: a critical review
}

\author{
Wei Zhu ${ }^{1,2}$, Che-Jen Lin ${ }^{1,3}$, Xun Wang ${ }^{1}$, Jonas Sommar ${ }^{1}$, Xuewu Fu ${ }^{1}$, and Xinbin Feng ${ }^{1}$ \\ ${ }^{1}$ State Key Laboratory of Environmental Geochemistry, Institute of Geochemistry, Chinese Academy of \\ Sciences, Guiyang 550002, China \\ ${ }^{2}$ Department of Chemistry, Umeå University, 90187 Umeå, Sweden \\ ${ }^{3}$ Center for Advances in Water and Air Quality, Lamar University, Beaumont, Texas 77710, USA \\ Correspondence to: Che-Jen Lin (jerry.lin@lamar.edu) and Xinbin Feng (fengxinbin@vip.skleg.cn)
}

Received: 31 December 2015 - Published in Atmos. Chem. Phys. Discuss.: 19 January 2016

Revised: 25 March 2016 - Accepted: 29 March 2016 - Published: 11 April 2016

\begin{abstract}
Reliable quantification of air-surface fluxes of elemental $\mathrm{Hg}$ vapor $\left(\mathrm{Hg}^{0}\right)$ is crucial for understanding mercury $(\mathrm{Hg})$ global biogeochemical cycles. There have been extensive measurements and modeling efforts devoted to estimating the exchange fluxes between the atmosphere and various surfaces (e.g., soil, canopies, water, snow, etc.) in the past three decades. However, large uncertainties remain due to the complexity of $\mathrm{Hg}^{0}$ bidirectional exchange, limitations of flux quantification techniques and challenges in model parameterization. In this study, we provide a critical review on the state of science in the atmosphere-surface exchange of $\mathrm{Hg}^{0}$. Specifically, the advancement of flux quantification techniques, mechanisms in driving the air-surface $\mathrm{Hg}$ exchange and modeling efforts are presented. Due to the semi-volatile nature of $\mathrm{Hg}^{0}$ and redox transformation of $\mathrm{Hg}$ in environmental media, $\mathrm{Hg}$ deposition and evasion are influenced by multiple environmental variables including seasonality, vegetative coverage and its life cycle, temperature, light, moisture, atmospheric turbulence and the presence of reactants (e.g., $\mathrm{O}_{3}$, radicals, etc.). However, the effects of these processes on flux have not been fundamentally and quantitatively determined, which limits the accuracy of flux modeling.

We compile an up-to-date global observational flux database and discuss the implication of flux data on the global $\mathrm{Hg}$ budget. Mean $\mathrm{Hg}^{0}$ fluxes obtained by micrometeorological measurements do not appear to be significantly greater than the fluxes measured by dynamic flux chamber methods over unpolluted surfaces ( $p=0.16$, one-tailed, Mann-Whitney $U$ test). The spatiotemporal coverage of ex-
\end{abstract}

isting $\mathrm{Hg}^{0}$ flux measurements is highly heterogeneous with large data gaps existing in multiple continents (Africa, South Asia, Middle East, South America and Australia). The magnitude of the evasion flux is strongly enhanced by human activities, particularly at contaminated sites. $\mathrm{Hg}^{0}$ flux observations in East Asia are comparatively larger in magnitude than the rest of the world, suggesting substantial re-emission of previously deposited mercury from anthropogenic sources. The $\mathrm{Hg}^{0}$ exchange over pristine surfaces (e.g., background soil and water) and vegetation needs better constraints for global analyses of the atmospheric Hg budget. The existing knowledge gap and the associated research needs for future measurements and modeling efforts for the air-surface exchange of $\mathrm{Hg}^{0}$ are discussed.

\section{Introduction}

Mercury $(\mathrm{Hg})$ is a global pollutant of broad concern due to its toxicity, bioaccumulation characteristics and adverse health effects (Driscoll et al., 2013), especially in its methylated forms such as monomethyl-mercury $\left(\mathrm{CH}_{3} \mathrm{Hg}\right)$ species and dimethyl-mercury $\left(\left(\mathrm{CH}_{3}\right)_{2} \mathrm{Hg}\right)$ (Clarkson and Magos, 2006). Fish consumption has been identified as the primary pathway for human exposure to $\mathrm{CH}_{3} \mathrm{Hg}$ (Mergler et al., 2007; Mason et al., 2012), while the exposure through rice cultivated in areas with $\mathrm{Hg}$ pollution (e.g., mining and smelting areas) also poses a risk (Feng et al., 2008a; Zhang et al., 2010). To protect human health and the environment from the adverse effects of mercury, a global treaty "Minamata Convention 
for Mercury" that regulates $\mathrm{Hg}$ emission reduction from anthropogenic sources has been signed by 128 countries since October 2013 (UNEP Minamata Convention, 2013). Emission of $\mathrm{Hg}$ into the atmosphere occurs from both natural processes and human activities. The release of $\mathrm{Hg}$ from natural surfaces has been estimated to account for two-thirds of global emissions (Fig. 1). However, this estimate is subject to large uncertainty because of the challenges in quantifying the flux and in understanding the mechanisms involved in the exchange process of elemental mercury vapor $\left(\mathrm{Hg}^{0}\right)$ (Selin, 2009; Zhang et al., 2009, 2012a; Gustin, 2011).

$\mathrm{Hg}$ emitted from anthropogenic sources include all atmospheric species: gaseous elemental $\mathrm{Hg}\left(\mathrm{Hg}^{0}, \mathrm{GEM}\right)$, gaseous oxidized $\mathrm{Hg}$ (GOM) and particulate-bound $\mathrm{Hg}$ (PBM) (Pacyna et al., 2006; AMAP/UNEP, 2013), while evasion derived from the Earth's surfaces is dominated by GEM (Gustin, 2011). Owing to the high deposition velocities of GOM and PBM (1-2 orders higher than GEM) (Zhang et al., 2009), GOM and PBM are readily deposited locally and regionally, while GEM is subject to long-range transport (e.g., hemispheric scale) and can deposit remotely from the emission sources (Lindberg et al., 2007; Gustin and Jaffe, 2010). Atmospheric $\mathrm{Hg}$ continuously goes through deposition and re-emission cycles while undergoing physical and chemical transformations (Lin and Pehkonen, 1999).

Extensive efforts have been devoted to understanding the spatial and temporal pattern of $\mathrm{Hg}^{0}$ exchange flux. Geogenically $\mathrm{Hg}$-enriched surfaces and anthropogenically polluted sites are strong $\mathrm{Hg}$ emission sources (Kocman et al., 2013). Emissions from natural sources and from previously deposited $\mathrm{Hg}^{0}$ on substrate surfaces are not analytically distinguishable using current measurement techniques (cf. Sect. 2). Direct measurement of $\mathrm{Hg}^{0}$ flux from the background surfaces is difficult due to small vertical $\mathrm{Hg}^{0}$ concentration gradients (therefore low flux) (Zhu et al., 2015a). Since the first application of a stainless steel dynamic flux chamber for $\mathrm{Hg}^{0}$ flux measurements over background lakes and soils in the 1980s (Schroeder et al., 1989; Xiao et al., 1991), significant advancements in the experimental approaches (e.g., dynamic flux chambers, micrometeorological methods, the $\mathrm{Hg}^{0} /{ }^{222} \mathrm{Rn}$ flux ratio, enriched isotope tracer methods, the open-path laser optical spectroscopic method and the $\mathrm{Hg}^{0}$ / $\mathrm{CO}$ ratio) have been made (Sommar et al., 2013a). However, a standard protocol for $\mathrm{Hg}^{0}$ flux quantification does not exist (Gustin, 2011; Zhu et al., 2015b), which complicates the comparison and interpretation of flux data reported in the literature (cf. Sect. 4).

In this study, we present a comprehensive review on the global observation of $\mathrm{Hg}^{0}$ flux in peer-reviewed literature, and provide a state-of-the-science assessment on the airsurface exchange of $\mathrm{Hg}^{0}$. Specifically, the advancement of flux quantification techniques, physicochemical factors driving the exchange process, existing field data of $\mathrm{Hg}^{0}$ flux and modeling efforts for scaling up the measured flux for global assessment are synthesized. Furthermore, the spatial and temporal characteristics of $\mathrm{Hg}^{0}$ flux, as well as the underlying influencing factors are investigated. Key knowledge gaps, future directions for field measurements and development of new-generation air-surface exchange model for $\mathrm{Hg}^{0}$ flux are discussed. Compared to the assessment by Agnan et al. (2016) that summarized air-surface exchange of $\mathrm{Hg}$ over terrestrial systems, our work differs in the following areas: (1) the approaches in data compilation and synthesis, (2) the coverage of flux data over different land uses (11 categories covering whole Earth surfaces vs. 6 categories of terrestrial surfaces in Agnan et al., 2016), (3) the inclusion of mechanistic discussion on flux quantification approaches and airsurfaces exchange processes, (4) the inclusion of flux modeling approaches and scale-up of flux data for global cycle implications and (5) the inclusion of more up-to-date field data and exclusion of laboratory data in the synthesis.

\section{Advances in $\mathrm{Hg}^{\mathbf{0}}$ flux quantification methods}

The theory and application of $\mathrm{Hg}^{0}$ flux measurement techniques have been documented extensively (Zhang et al., 2009; Gustin, 2011; Sommar et al., 2013a). Here we focus on the developments, advantages and disadvantages and comparability and uncertainties of different flux quantification techniques. DFCs, micrometeorological techniques (MM) and bulk methods (e.g., the $\mathrm{Hg}^{0} /{ }^{222} \mathrm{Rn}$ flux ratio, enriched isotope tracers) are the mostly widely applied approaches for surface-atmosphere $\mathrm{Hg}^{0}$ flux quantification (Schroeder et al., 1989; Xiao et al., 1991; Kim and Lindberg, 1995; Kim et al., 1995; Cobos et al., 2002; Amyot et al., 2004; Olofsson et al., 2005; Obrist et al., 2006; Bash and Miller, 2008; Lin et al., 2012; Slemr et al., 2013; Zhu et al., 2013c), of which DFCs and MM techniques account for $>95 \%$ of all observations documented to date (cf. Sect. 4). Openpath pulsed laser optical spectroscopic (LIDAR) method and $\mathrm{Hg}^{0} / \mathrm{CO}$ ratio were applied to estimate $\mathrm{Hg}$ emission from area/regional sources (e.g., LIDAR: mining areas, industrial plants, geothermal sites; $\mathrm{Hg}^{0}$ / CO ratio: continental level atmospheric Hg transport) (Aldén et al., 1982; Edner et al., 1991; Sjöholm et al., 2004; Jaffe et al., 2005; Fu et al., 2015a). There has not been a standardized protocol for any of the techniques (e.g., instrumentation set-up, operation parameters) (Gustin, 2011; Zhu et al., 2015b). Recent collocated measurements and uncertainties analysis emphasized the importance of method standardization and processing of field data acquired by the measurement systems (Fritsche et al., 2008b; Converse et al., 2010; Zhu et al., 2015a). Application of the appropriate flux measurement technique depends on the scalar detection accuracy, sensor response frequency and level of automation (Sutton et al., 2007). The traditional standard procedure of sampling ambient air $\mathrm{Hg}^{0}$ is by enhancement collection onto traps containing gold (Fitzgerald and Gill, 1979; Slemr et al., 1979). A wide-spread continuous $\mathrm{Hg}^{0}$ monitor is the automated dual channel, single amal- 


\section{Atmospheric reservoir (5100-5600)}

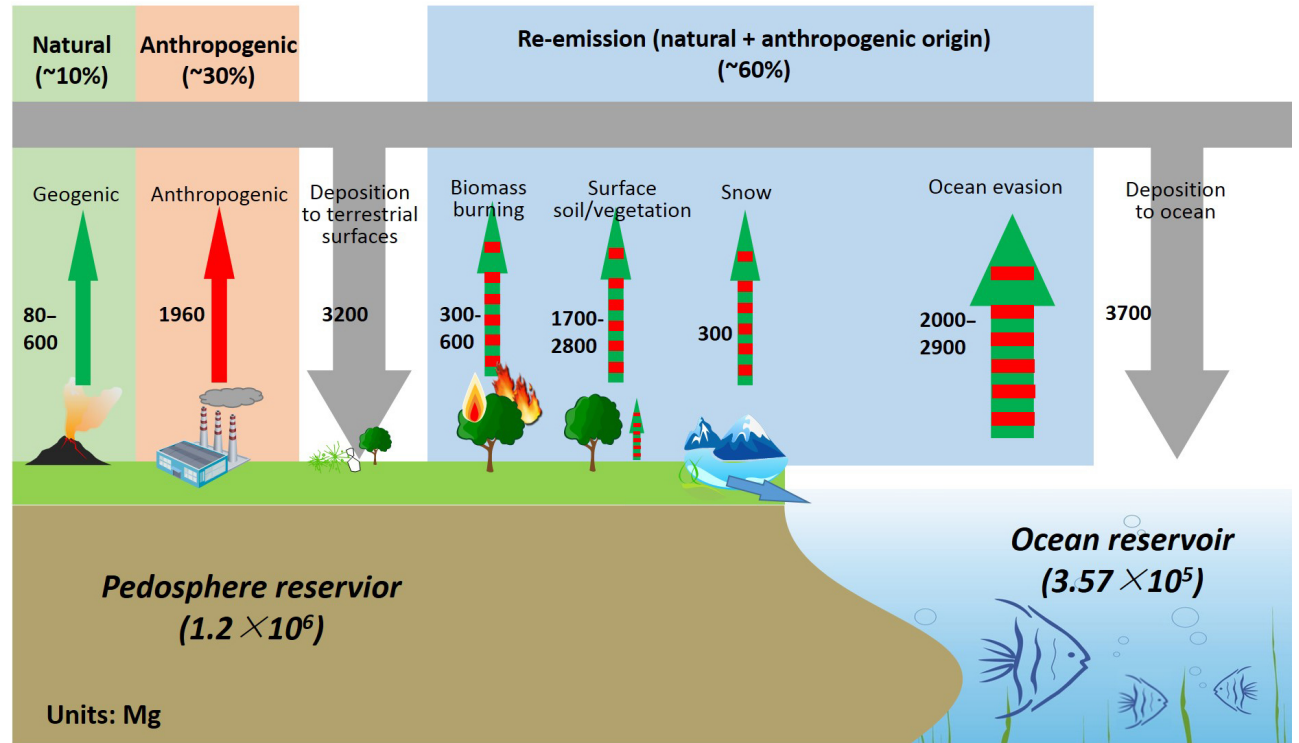

Figure 1. The most recent $\mathrm{Hg}$ reservoirs and global atmosphere $\mathrm{Hg}$ inventory illustrating the exchange flux between atmosphere and Earth surfaces. Adapted from Selin (2009); Gustin and Jaffe (2010); Soerensen et al. (2010); Corbitt et al. (2011); Mason et al. (2012); AMAP/UNEP (2013).

gamation, cold vapor atomic fluorescence analyzer (Model 2537, Tekran Instruments Corp.), which relies on this principle. The certified detection limit is $<0.1 \mathrm{ng} \mathrm{m}^{-3}$. However, the pre-concentration procedure takes $\geq 2.5 \mathrm{~min}$ and therefore real-time, high-frequency data acquisition is not possible (Gustin, 2011; Fu et al., 2012b; Gustin et al., 2013, 2015). Later on, monitoring ambient air $\mathrm{Hg}^{0}$ with relative higher frequency (up to $1 \mathrm{~Hz}$ ) was achieved by using Lumex RA-915+ Zeeman atomic absorption spectrometry (AAS) analyzer operating without pre-concentration. However, the instrument has a detection limit of $\sim 1 \mathrm{ng} \mathrm{m}^{-3}$ and therefore is preferred for industrial level studies but applicable under ambient $\mathrm{Hg}^{0}$ concentrations (Holland, 2005). More recently, a high frequency $(25 \mathrm{~Hz})$ cavity ring-down spectroscopy (CRDS) sensor has been deployed for $\mathrm{Hg}^{0}$ concentration measurement, but it has a higher detection limit $\left(>0.35 \mathrm{ng} \mathrm{m}^{-3}\right)$ and suffers from the sensor's baseline drifting and interferences with $\mathrm{O}_{3}$ (Faïn et al., 2010; Pierce et al., 2013). Another laser technique, the laser-induced fluorescence sensor, has been designed and successfully applied for up to 1 day of continuous measurement with improved detection limit $\left(\sim 15 \mathrm{pg} \mathrm{m}^{-3}\right)$ (Bauer et al., 2002, 2014). However, both methods have not yet been proven for application in long-term field measurements. The coupling with a commercial instrument (e.g., Tekran ${ }^{\circledR}$ 2537) renders continuous and unattended flux measurements by DFC or MM techniques to be accomplished and are most widely deployed over various surfaces (cf. Sect. 4). However, this implementation is associated with a significant cost because the expense of the
$\mathrm{Hg}^{0}$ analyzer normally exceeds the rest of flux measurement system.

\subsection{Dynamic flux chambers}

The DFC method (footprint generally $<0.1 \mathrm{~m}^{2}$ ) is a frequently used $\mathrm{Hg}^{0}$ flux measurement technique over soils, water surfaces and low-stand grass due to its relatively low cost, portability and versatility (Sommar et al., 2013a). DFCs operating under steady-state (Xiao et al., 1991; Carpi and Lindberg, 1998) and non-steady-state conditions (Rinklebe et al., 2009) are used in $\mathrm{Hg}$ research with the former configuration being by far the most common. Dynamic flux bags (DFB) have been applied for flux measurements over tall grass and tree branches (Zhang et al., 2005; Graydon et al., 2006; Poissant et al., 2008). Laboratory mesocosms probing whole ecosystem $\mathrm{Hg}$ exchange have also been attempted; a $180 \times 10^{3} \mathrm{~L}$ chamber $\left(7.3 \times 5.5 \times 4.5 \mathrm{~m}^{3}\right)$ was deployed for quantifying soil-plant-atmosphere flux (Gustin et al., 2004; Obrist et al., 2005; Stamenkovic and Gustin, 2007; Stamenkovic et al., 2008). Construction materials such as fluorinated ethylene propylene (FEP) films and quartz have been recommended for DFCs due to its high actinic light transmittance and low blank (Kim and Lindberg, 1995; Carpi et al., 2007; Lin et al., 2012). Reported DFCs volumes and flushing flow rates range from 1 to $32 \mathrm{~L}$ and 1.5 to $20 \mathrm{~L} \mathrm{~min}^{-1}$, resulting in a turnover time (TOT) ranging from 0.1 to $14 \mathrm{~min}$ (Eckley et al., 2010; Zhu et al., 2011). Using DFCs, the $\mathrm{Hg}^{0}$ flux is calculated as follows: 
$F=\frac{Q\left(C_{\text {out }}-C_{\text {in }}\right)}{A}$,

where $F$ is the $\mathrm{Hg}^{0}$ flux $\left(\mathrm{ng} \mathrm{m}^{-2} \mathrm{~h}^{-1}\right), Q$ is the DFC internal flushing flow rate $\left(\mathrm{m}^{-3} \mathrm{~h}^{-1}\right), A$ is the DFC footprint, $C_{\text {out }}$ and $C_{\text {in }}$ are the $\mathrm{Hg}^{0}$ concentrations at the DFC outlet and inlet, respectively. Equation (1) relies on mass balance calculations of two $C_{\text {out }}$ and two $C_{\text {in }}$ measurements, alternately, and assumes that the surface shear velocity over the DFC footprint is uniform and therefore results in a constant flux spatially over the wetted surface. Distinct $\mathrm{Hg}^{0}$ fluxes have been observed using DFCs of different design shapes under similar environmental conditions (Eckley et al., 2010). Lin et al. (2012) investigated the internal flow field and $\mathrm{Hg}^{0}$ concentration distribution in two commonly designed DFCs (i.e., rectangular and dome-shaped chambers) and showed that the airstream inside the DFCs is not uniform and the surface shear flow is divergent over the footprint, resulting in a non-uniform $\mathrm{Hg}^{0}$ concentration gradient over the substrate surface. Eckley et al. (2010) systematically investigated effects of fabrication material, footprint, chamber dimensions including port positions and flushing flow rates on the measured $\mathrm{Hg}^{0}$ flux by DFCs. Consistent with previous studies, the flushing flow rate is among the most influential factor that if varied may induce up to 1 order of magnitude differences in the observed fluxes (Gustin et al., 1999; Wallschläger et al., 1999; Gillis and Miller, 2000a; Lindberg et al., 2002c; Zhang et al., 2002). Computational fluid dynamic modeling of DFC mass transfer has indicated that a smaller diffusion resistance at a higher flushing flow rate yielded a higher measured flux. However, due to the non-uniform internal $\mathrm{Hg}^{0}$ concentration gradient, the measured $\mathrm{Hg}^{0}$ flux from substrates may change unpredictably when the flushing flow rate varies (Eckley et al., 2010; Lin et al., 2012), which should be taken into consideration when the fluxes obtained by DFCs of different designs and flushing flow rates cannot be directly compared. Another limitation of DFCs is the isolation of chamber internal substrate surface from ambient conditions. This excludes the effect of atmospheric turbulence and therefore may cause a large uncertainty when using DFC data as in-put for scale-up estimations. Lin et al. (2012) proposed an aerodynamically designed chamber (NDFC) which enables producing a uniform surface friction velocity to link with ambient shear condition to rescale to the ambient flux using Eq. (2), which allows the utilization of the ambient surface shear condition rather than artificial steady flushing flow rate to calculate the flux:

$F=\frac{Q\left(C_{\text {out }}-C_{\text {in }}\right)}{A} \cdot \frac{k_{\text {mass }(\mathrm{a})}}{k_{\text {mass }(\mathrm{DFC})}}$,

where $k_{\text {mass(a) }}$ is the overall mass transfer coefficient under ambient conditions, and $k_{\text {mass(DFC) }}$ is the overall mass transfer coefficient in the DFC measurement area.
In addition to the uncertainties caused by varying flushing flow rates, altered short and long wave radiation balances within DFCs resulting in a modified micro-environment were found to bias the observed fluxes (Zhu et al., 2015a). DFC flux is measured through intermittent sampling of ambient and chamber air for $\mathrm{Hg}^{0}$ analysis using a single detector (Lindberg et al., 2002c), which assumes that ambient $\mathrm{Hg}^{0}$ variability is negligible during air sampling. At locations where significant variation in $\mathrm{Hg}^{0}$ concentrations exist (e.g., sites with anthropogenic emission sources), Eckley et al. (2011a) proposed a data assimilation protocol: $\left|\Delta C_{\mathrm{oi}}\right|>\left|\Delta C_{i i}\right|$ should be valid for each of the calculated fluxes, otherwise the flux should be rejected $\left(\Delta C_{\mathrm{oi}}\right.$ is the difference between $C_{\text {out }}$ and the average of two $C_{\text {in }}$ which before and after taking $C_{\text {out }}$, while $\Delta C_{i i}$ is the difference between above two $C_{\text {in }}$ ). The concern about influencing plant physiology restricts the deployment of small DFCs to short term field measurements over the same vegetated plot. Given the small footprint and that $\mathrm{Hg}^{0}$ fluxes over terrestrial surfaces are profoundly variable in space and time, replication of DFC measurements are thus preferred but often not carried out.

\subsection{Micrometeorological methods}

MM methods differ in measurement principles and the spatial scale of flux footprints compared to DFCs and have the capability of measuring ecosystem-scale (typically hectare scale) fluxes under undisturbed conditions and represent preferred flux quantification techniques over vegetated landscapes. MM techniques for background $\mathrm{Hg}^{0}$ flux measurements are currently comprised of the relaxed eddy accumulation method (REA), the aerodynamic gradient method (AGM) and the modified Bowen-ratio method (MBR). The preferred MM technique, eddy covariance (EC), which is a direct flux measurement method without any applications of empirical constants, requires a fast response $(\sim 10 \mathrm{~Hz})$ gas analyzer, and has not been successfully implemented for regular $\mathrm{Hg}^{0}$ flux measurements (Aubinet et al., 2012). Recently, Pierce et al. (2015) reported the first field trial of CRDS-EC flux measurements over $\mathrm{Hg}$-enriched soils with a flux detection limit of $32 \mathrm{ng} \mathrm{m}^{-2} \mathrm{~h}^{-1}$, offered the opportunity to high frequently monitoring $\mathrm{Hg}^{0}$ flux from $\mathrm{Hg}$-enriched surfaces. However, the present CRDS-EC technique must be further advanced for $\mathrm{Hg}^{0}$ flux measurement at most, if not all, background sites. Sommar et al. (2013a) and Zhu et al. (2015b) detailed the theory, deployment and computation of existing MM approaches for measuring $\mathrm{Hg}^{0}$ fluxes. Gradient methods rely on quantifying the vertical concentration gradient (two or more sampling heights), turbulent parameters (AGM) or scalar concentration gradient (MBR) and scalar EC-fluxes. A major advantage of REA method is that the REA up- and down-draft sampling conducted at one height overcomes the uncertainties associated with the following: (1) footprint differences due to two height samplings in using gradient meth- 
ods and (2) possible oxidation/reduction introduced through the forming or loss of $\mathrm{Hg}^{0}$ between the two heights. On the other hand, the analytical requirement for REA is more stringent than for the gradient methods, especially under low turbulent conditions, increasing the demand on the precision of the sampling and chemical analysis (Zhu et al., 2015a).

The REA method has been deployed for flux measurements for agricultural lands, forest canopies, wetlands and urban settings (Cobos et al., 2002; Olofsson et al., 2005; Bash and Miller, 2009; Osterwalder et al., 2016; Sommar et al., 2013b). The AGM method has been used over grasslands, agricultural lands, salt marshes, landfills and snow (Lee et al., 2000; Kim et al., 2001, 2003; Cobbett et al., 2007; Cobbett and Van Heyst, 2007; Fritsche et al., 2008b, c; Baya and Van Heyst, 2010). The MBR method has been set up in grasslands, forest floors, agricultural lands, lakes, wetlands and snow (Lindberg et al., 1992, 1995b, 2002b; 1998; Lindberg and Meyers, 2001; Brooks et al., 2006; Fritsche et al., 2008b; Converse et al., 2010). The theoretical and application requirements of micrometeorology are less restricted for large areas of uniform vegetation (or soil) in flat landscapes, where an atmospheric surface layer develops and the horizontal flux variability is low in the absence of pollution plumes and the flux above the surface remains constant with height (Wesely and Hicks, 2000). Under these turbulent exchange conditions, the flux acquired at the measurement height resembles the actual flux at the surface under measurement. There are several potential causes that can invalidate the above assumptions. For instance, the advection of $\mathrm{Hg}^{0}$ from sources near the measurement site may occur. It is known that local point sources of $\mathrm{Hg}^{0}$ can affect MM measurements downwind (Bash and Miller, 2007). Loubet et al. (2009) estimated such advection errors in $\mathrm{NH}_{3}$ gradient fluxes resulting in 2.1 to $52 \%$ of vertical fluxes at a monitoring site at $810 \mathrm{~m}$ downwind of an $\mathrm{NH}_{3}$ source (a farm building) implying a significant error contribution from advection. Large variation of $\mathrm{Hg}^{0}$ fluxes measured by MBR methods were also reported at nighttime as a result of advection in the Nevada STORM project; however, the errors have not been quantified (Gustin et al., 1999). For $\mathrm{Hg}^{0}$ fluxes over forest canopies, the influence of within-canopy source and sink terms on the net ecosystem flux has not been evaluated. Multiple height gradients/REA measurements is needed to resolve the true flux. Since there is not a reliable sensitive $\mathrm{Hg}^{0}$ sensor at a high measurement frequency, an empirical multiplication factor or proxy scalar is required for computing all $\mathrm{MM}-\mathrm{Hg}^{0}$ fluxes (e.g., relaxation coefficient $\beta$ derived from a selected proxy scalar for REA, eddy diffusivity $K_{\mathrm{H}}$ derived from sensible heat for AGM, proxy scalar such as sensible heat, $\mathrm{CO}_{2}$ as well as $\mathrm{H}_{2} \mathrm{O}$ flux for MBR) (Lindberg et al., 1995a; Edwards et al., 2005; Baya and Van Heyst, 2010; Zhu et al., 2015b). These empirical factors may introduce uncertainties when the proxy scalar value is small, which frequently occurs during dawn and dusk and under the condition of low atmospheric turbulence. Proxy scalar inferred relaxation coeffi- cients $\left(\beta_{\mathrm{CO}_{2}}, \beta_{T_{\mathrm{S}}}\right.$ and $\left.\beta_{\mathrm{H}_{2} \mathrm{O}}\right)$ were typically not significantly different $(\sim 0.56)$ during a campaign above wheat agricultural land, while all $\beta$ values were highly variable when the corresponding scalar flux was close to zero (Gronholm et al., 2008; Sommar et al., 2013b). Converse et al. (2010) reported $\mathrm{Hg}^{0}$ fluxes over a wetland meadow using collocated AGM and MBR methods for four campaigns during an entire year. They found comparable fluxes in the summer, while source/sink characteristics reversed between the two methods in fall and winter. Zhu et al. (2015b) found that the AGM and MBR methods observed similar $\mathrm{Hg}^{0}$ fluxes when absolute sensible heat flux was $>20 \mathrm{~W} \mathrm{~m}^{-2}$; and the agreement was not satisfactory when the absolute sensible heat flux was $<20 \mathrm{~W} \mathrm{~m}^{-2}$. Rejecting flux data collected under low turbulence conditions can bias the integrated flux over time (Mauder and Foken, 2004); and adequate data rejection and correction approaches need to be developed (Aubinet et al., 2012).

\subsection{Comparability of flux measured by micrometeorological and chamber methods}

Limited efforts have been devoted to understanding the flux disparity caused by different flux measurement techniques. The Nevada STORMS project was the first attempt using 11 collocated measurements (7 DFC methods and 4 gradientbased MM methods) to simultaneously quantify $\mathrm{Hg}^{0}$ fluxes from Hg-enriched bare soils in September 1997 (Gustin et al., 1999; Lindberg et al., 1999; Poissant et al., 1999; Wallschläger et al., 1999). In the campaign, the mean fluxes obtained using MM methods were 3 times greater than those obtained by DFCs (Fig. 2a). One possible reason for the low observed fluxes by DFC was the small flushing flow rates (corresponding TOT: $1.1-24 \mathrm{~min}$ ) that were not sufficient in eliminating the accumulated $\mathrm{Hg}^{0}$ in the DFC and subsequently suppressed $\mathrm{Hg}^{0}$ evasion. Later, Gustin and coworkers extended the study at the same site using a 1L polycarbonate DFC (TOT: $0.2 \mathrm{~min}$ ) (Engle et al., 2001) and a MBR method (Gustin et al., 1999) in October 1998 (Gustin, 2011). Although the MBR method showed substantial flux variability, DFC and MM fluxes were not significantly different $(p>0.05)$ for dry and wet diel flux cycles (Fig. 2b). Two challenges in comparing MM and DFCs fluxes in these studies were the site heterogeneity (1.2$14.6 \mu \mathrm{g} \mathrm{Hg} \mathrm{g}^{-1}$ in soil) and the footprint differences. The footprint of MM methods was estimated to be $40-70 \mathrm{~m}$ upwind from the sampling sites $\left(50-200 \mathrm{~m}^{2}\right)$, while DFC covered only $0.12-0.3 \mathrm{~m}^{2}$ (Gustin et al., 1999). Recently, an integrated field $\mathrm{Hg}^{0}$ flux methods intercomparison project measured $\mathrm{Hg}^{0}$ flux from a background homogenized agricultural field $\left(\sim 45 \mathrm{ng} \mathrm{Hg} \mathrm{g}^{-1}\right)$ using REA, AGM, MBR, a polycarbonate NDFC (TOT: $0.47 \mathrm{~min}$ ) and a traditional quartz DFC (TDFC, TOT: $0.32 \mathrm{~min}$ ) (Fu et al., 2008a; Zhu et al., 2015a, b). Overall, the MM fluxes showed highly dynamic temporal variability while the DFCs followed a grad- 

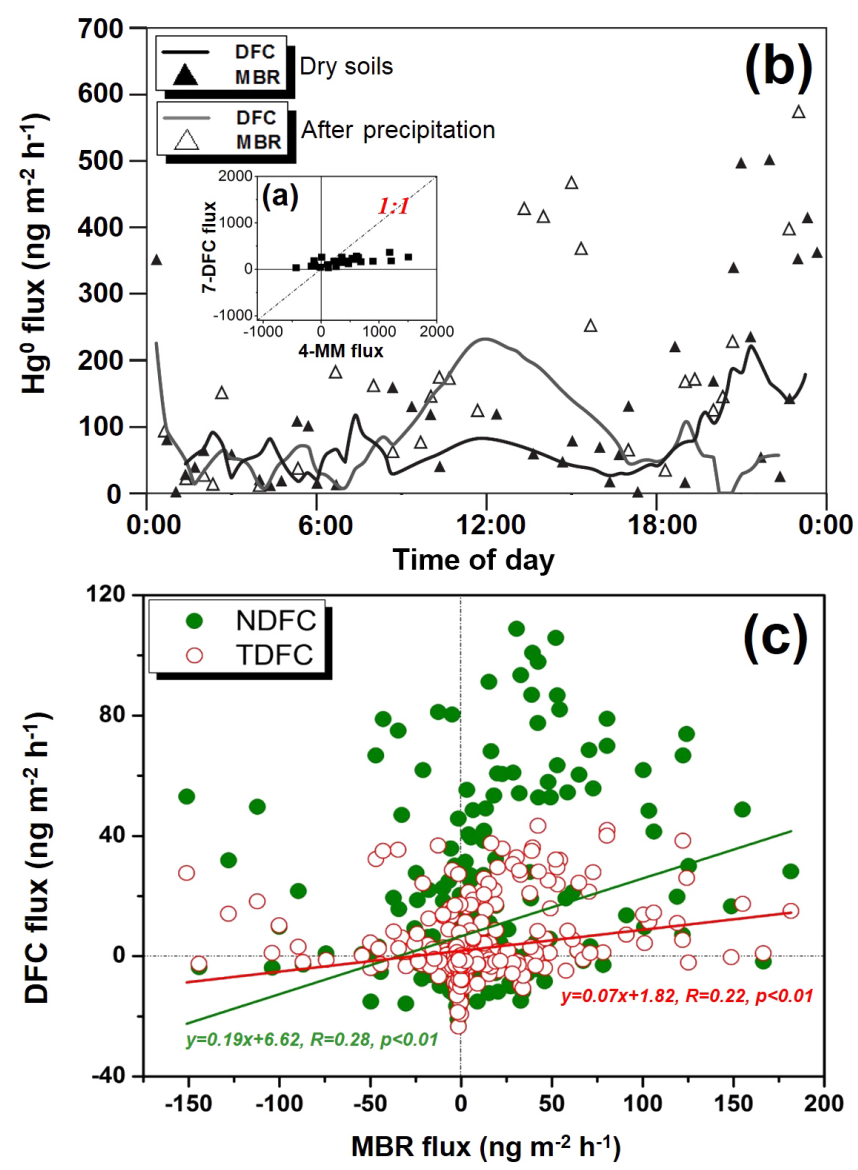

Figure 2. Field-collocated DFCs and MM techniques observed fluxes from two intercomparison studies. (a) Inlaid scatter plot of averaged 4-MM flux vs. averaged 7-DFC flux (TOT: 1.1-24 min) in Hg-enriched Nevada STORMS site in September 1997 (Gustin et al., 1999); (b) Diel evolution of $\mathrm{Hg}^{0}$ flux measured using a $1 \mathrm{~L}$ polycarbonate-DFC (TOT: $0.2 \mathrm{~min}$ ) and MBR method at same Nevada STORMS site in October 1998 (Gustin, 2011); (b) Scatter plot of DFC with traditional/novel designs (TDFC/NDFC) vs. MBR $\mathrm{Hg}^{0}$ flux obtained in Yucheng intercomparison project (Zhu et al., 2015b).

ual diel cycle similar to those for temperature and solar irradiance. REA observed a broader flux distribution similar to $\mathrm{NH}_{3}$ and $\mathrm{CH}_{4}$ fluxes observed by MM techniques (Beverland et al., 1996; Moncrieff et al., 1998; Nemitz et al., 2001). The median fluxes obtained by REA, AGM and MBR were not significantly different (Friedman two-way analysis, $\chi^{2}=1.29<\chi_{p=0.05}^{2}=5.99$ ). Over a 3-week period, NDFC obtained a comparable mean flux with AGM and MBR, which are approximately 3 times that of the TDFC flux, implying that NDFC potentially reduced the uncertainty using real atmospheric boundary shear condition to rescale (Lin et al., 2012). However, the correlation between NDFC/TDFC and MBR fluxes were weak because of the high variability of MM fluxes (Fig. 2c). Pierce et al. (2015) observed comparable mean fluxes using simultaneous measurements of CRDS-
EC, MBR and DFC $\left(849,1309\right.$ and $1105 \mathrm{ng} \mathrm{m}^{-2} \mathrm{~h}^{-1}$, respectively) over $\mathrm{Hg}$-enriched soils, similar flux patterns were recorded from CRDS-EC and MBR.

Figure 3 shows the comparisons of $\mathrm{Hg}^{0}$ fluxes measured by MM methods and DFCs from relative homogeneous landscapes reported in the literature (each data point represents campaign/site-based average flux, which constitutes hourly, daily and seasonal flux, cf. Sect. 4, substrate total $\left.\mathrm{Hg}<0.3 \mu \mathrm{g} \mathrm{Hg} \mathrm{g}^{-1}\right)$. MM methods yield a broader $\mathrm{Hg}^{0}$ flux range compared to DFCs methods, consistent with the field campaigns using collocated measurements (Zhu et al., 2015b). MM mean flux is higher than DFCs flux by a factor of approximately 2, which may be a result of the fact that a large fraction of DFC measurements utilized a relative low TOT underestimating the surface flux. However, a Mann-Whitney $U$ test indicated that the differences between the two methods are not significant ( $p=0.16$, onetailed). Probabilities of the two data sets showed positive skewness (4.2 and 3.9 for MM and DFCs, respectively) and kurtosis (19.6 and 27.2) caused by those high flux observations, likely resulting from asymmetrical data distribution as well as differences in measurement sites and periods. The flux data of MM methods in Fig. 3 were mostly obtained from agricultural fields (33\%) and grasslands (36\%), while the data of DFC methods were mainly from background sites $(68 \%)$; and MM measurement generally covered a longer period (weeks to year) compared to DFC measurements, which lasted a much shorter period (hours, days to a few weeks). Typically, significant $\mathrm{Hg}^{0}$ evasion is observed during daytime, while deposition, bidirectional exchange, or mild emission occurs at nighttime (cf. Sect. 4). Agnan et al. (2016) summarized MM and DFC fluxes observed in laboratory and during field campaigns over terrestrial substrates, and found that the observed median MM flux $\left(-0.01 \mathrm{ng} \mathrm{m}^{-2} \mathrm{~h}^{-1}, n=51\right)$ was statistically smaller than the median DFC flux $\left(0.5\right.$ and $1.75 \mathrm{ng} \mathrm{m}^{-2} \mathrm{~h}^{-1}$ for flushing flow rate $\leq 2 \mathrm{~L} \mathrm{~min}^{-1}$ and $>2 \mathrm{~L} \mathrm{~min}^{-1}, p<0.05$ ). They suggested that an elevated flushing flow rate generated a partial vacuum inside DFC and created an artificial $\mathrm{Hg}^{0}$ flux from the soil even at $<2 \mathrm{~L} \mathrm{~min}^{-1}$. However, this hypothesis is not supported by the large $\mathrm{Hg}^{0}$ concentration gradient (inside and outside the DFC) formed at low flushing flow rate (Zhang et al., 2002; Eckley et al., 2010). An alternative explanation is that $\mathrm{MM}$ measurements were predominantly deployed for background vegetated surfaces while DFCs were mainly applied for soil surfaces, the difference in the source/sink characteristics over vegetation and bare soils might have caused the differences in the median fluxes. 


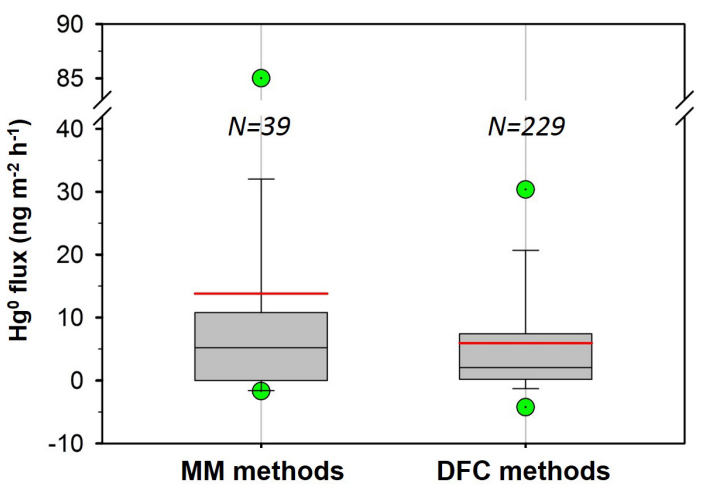

Figure 3. Box and whisker plots of $\mathrm{Hg}^{0}$ fluxes measured by MM methods and DFC methods. (Flux data including measurements from background soils, agricultural fields, grasslands and wetlands at substrate total $\mathrm{Hg}$ lower than $0.3 \mu \mathrm{g} \mathrm{Hg} \mathrm{g}^{-1}$, data source: Table 1 . The two box horizontal border lines indicate 25th and 75th percentiles, whiskers represent 10th and 90th percentiles and outliers (green circles) indicate 5th and 95th percentiles from bottom to top. Red line and black line indicate mean and median flux).

\section{Factors influencing air-surface $\mathrm{Hg}^{\mathbf{0}}$ exchange}

\subsection{Air-soil Hg exchange}

Meteorological parameters (e.g., solar radiation, soil/air temperature, atmospheric turbulence), soil substrate characteristics (e.g., Hg content, soil moisture, organic matter, porosity and microbial activity), and ambient air characteristics (e.g., $\mathrm{Hg}^{0}$ and $\mathrm{O}_{3}$ concentration) can influence the air-surface exchange of $\mathrm{Hg}^{0}$. Changes of these factors force two controlling processes: (1) the formation of evaporable $\mathrm{Hg}^{0}$ and (2) the mass transfer of $\mathrm{Hg}^{0}$. Solar radiation has been found to be highly positively correlated with soil $\mathrm{Hg}^{0}$ flux (Carpi and Lindberg, 1997; Boudala et al., 2000; Zhang et al., 2001; Gustin et al., 2002; Poissant et al., 2004a; Bahlmann et al., 2006), which is generally regarded as enhancing $\mathrm{Hg}^{\mathrm{II}}$ reduction and therefore facilitating $\mathrm{Hg}^{0}$ evasion (Gustin et al., 2002). Actinic light spectral analysis suggested UV-B can reduce $\mathrm{Hg}^{\mathrm{II}}$ to $\mathrm{Hg}^{0}$ over soil, while UV-A and visible light have a much lower enhancement (Moore and Carpi, 2005; Choi and Holsen, 2009b). Temperature is an important factor promoting $\mathrm{Hg}^{0}$ evasion, typically following the Arrhenius equation (Carpi and Lindberg, 1997; Poissant and Casimir, 1998; Gustin et al., 2002). However, the Arrhenius relationship cannot explain the $\mathrm{Hg}^{0}$ flux spikes at sub-zero temperatures, implying that other mechanisms such as the expansion and contraction of liquid fraction in soil substrates occurred (Corbett-Hains et al., 2012). Atmospheric turbulence (i.e., wind and surface friction velocity) is another factor that drives the $\mathrm{Hg}^{0}$ release from soil (Lindberg et al., 1999; Wallschläger et al., 1999). Increased turbulence enhances $\mathrm{Hg}^{0}$ mass transfer and promotes $\mathrm{Hg}^{0}$ desorption from soil (Gustin et al., 1997; Lindberg et al., 2002c; Zhang et al., 2002; Eckley et al., 2010; Lin et al., 2012).

Soil types, soil moisture and $\mathrm{Hg}$ content in soil are also important factors influencing observed $\mathrm{Hg}^{0}$ flux (Xu et al., 1999; Kocman and Horvat, 2010; Lin et al., 2010a). Lindberg et al. (1999) observed that rainfall and irrigation enhances soil $\mathrm{Hg}^{0}$ emission by 1 order of magnitude. Subsequent studies supported that adding water to dry soil promotes $\mathrm{Hg}$ reduction and that water molecules likely replace soil $\mathrm{Hg}^{0}$ binding sites and facilitates $\mathrm{Hg}^{0}$ emission. In saturated soil, $\mathrm{Hg}$ emission is suppressed because the soil pore space is filled with water, which hampers Hg mass transfer (Gillis and Miller, 2000b; Gustin and Stamenkovic, 2005). Pannu et al. (2014) investigated $\mathrm{Hg}^{0}$ flux over boreal soil by manipulating soil moisture, a maximum flux was observed at $60 \%$ soil moisture (water filled pore space), whereas flux became inhibited at $80 \%$. Repeated rewetting experiments showed a smaller increase in emission, implying "volatizable" $\mathrm{Hg}^{0}$ needs to be resupplied by means of reduction and dry deposition after a wetting event (Gustin and Stamenkovic, 2005; Song and Van Heyst, 2005; Eckley et al., 2011b). Soil organic matter (SOM) have a strong affinity with $\mathrm{Hg}^{0}$ and form stable complexes with $\mathrm{Hg}^{\mathrm{II}}$ (Grigal, 2003; Skyllberg et al., 2006), and therefore diminish soil $\mathrm{Hg}^{0}$ efflux (Yang et al., 2007). Mauclair et al. (2008) measured $\mathrm{Hg}^{0}$ flux from sand $\left(0.5 \mu \mathrm{g} \mathrm{Hg} \mathrm{g}^{-1}\right)$ spiked with humic substances; and found that $\mathrm{Hg}^{0}$ flux decreased sharply by incremental addition of up to $0.1 \%$ of humic matter. Higher soil porosity and enhanced soil disturbance have been suggested to facilitate $\mathrm{Hg}^{\mathrm{II}}$ reduction and $\mathrm{Hg}^{0}$ transfer from soil $(\mathrm{Fu}$ et al., 2012a; Bash and Miller, 2007). Small soil grain size, clay and silt occurrence with higher surface area and $\mathrm{Hg}$ content, showed higher $\mathrm{Hg}^{0}$ flux (Edwards, et al., 2001; Gustin et al., 2002). Microbial-induced reduction can enhance $\mathrm{Hg}^{0}$ evasion but to a lesser extent (Fritsche et al., 2008a; Choi and Holsen, 2009b). Higher flux has also been observed by increasing soil $\mathrm{pH}$ value (Yang et al., 2007).

Elevated ambient $\mathrm{Hg}^{0}$ concentration has been found to suppress $\mathrm{Hg}^{0}$ flux by reducing the $\mathrm{Hg}^{0}$ concentration gradient at the interfacial surfaces (Xin and Gustin, 2007). At locations where ambient $\mathrm{Hg}$ concentration is high (e.g., mining sites, landfills), deposition is predominately observed despite of influence of meteorological factors (Bash and Miller, 2007; Wang et al., 2007b; Zhu et al., 2013c). Atmospheric $\mathrm{O}_{3}$ has been found to induce not-yet-understood chemical processes that enhance $\mathrm{Hg}^{0}$ emission from soil in the dark (Zhang et al., 2008). Laboratory experiments have shown that $\mathrm{Hg}^{0}$ flux from soils with $\mathrm{Hg}^{\mathrm{II}}$ as the dominant species can be enhanced by 1.7 to 51 times in the presence of $\mathrm{O}_{3}(50$ $70 \mathrm{ppb}$ ), and be decreased by $>75 \%$ over $\mathrm{Hg}^{0}$-amended soils (Engle et al., 2005). Environmental factors interact naturally (e.g., irradiation and temperature), which can impose synergistic and antagonistic effects on forcing $\mathrm{Hg}^{0}$ flux changes (Gustin and Stamenkovic, 2005). Figure 4 shows the individual effects and synergism between solar radiation, air tem- 


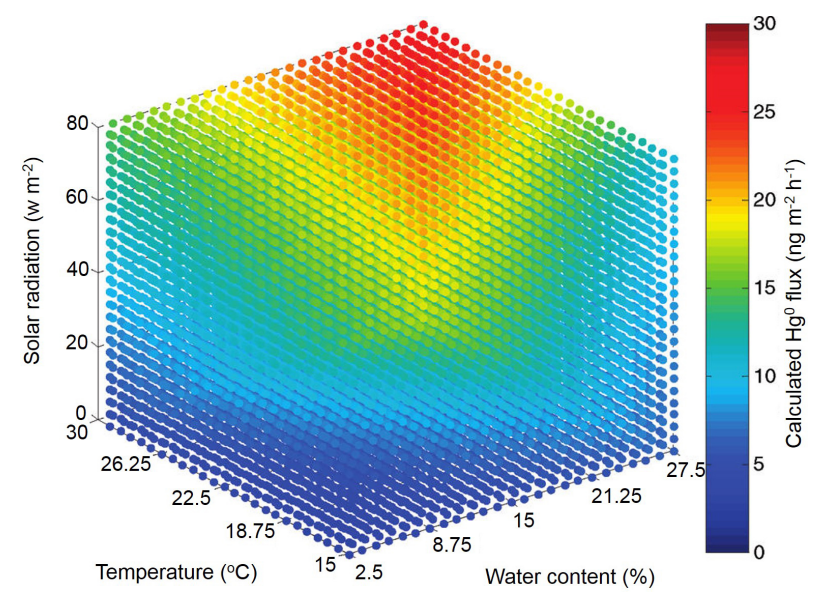

Figure 4. 4-D graphical visualization of the synergetic effect of air temperature, soil water content and solar radiation on the measured $\mathrm{Hg}^{0}$ flux from soil (Lin et al., 2010a).

perature and water content on $\mathrm{Hg}^{0}$ flux from a typical low organic content soil $(\sim 1.5 \mathrm{wt} \%)$ (Lin et al., 2010a). The three individual factors enhance flux by $90-140 \%$, while two-factor synergetic effect accounts for additional 20-30\% enhancement.

\subsection{Air-vegetation $\mathrm{Hg}^{0}$ exchange}

Vegetation alters air-ecosystem $\mathrm{Hg}^{0}$ flux through (1) changing environmental variables at ground surfaces (e.g., reducing solar radiation, temperature and friction velocity) (Gustin et al., 2004), and (2) providing active surfaces for $\mathrm{Hg}$ uptake. Deforestation followed by biomass harvesting can increase forest floor irradiation and temperature and therefore enhanced $\mathrm{Hg}^{0}$ emission (Carpi et al., 2014; Mazur et al., 2014). Carpi et al. (2014) reported forest floor soil fluxes of $-0.73 \pm 1.84$ and $0.33 \pm 0.09 \mathrm{ng} \mathrm{m}^{-2} \mathrm{~h}^{-1}$ from intact New England and Amazon forest floors, respectively. Substantial emission fluxes at $9.13 \pm 2.08,21.2 \pm 0.35 \mathrm{ng} \mathrm{m}^{-2} \mathrm{~h}^{-1}$ were observed after deforestation, suggesting forest coverage effectively reduced ground floor $\mathrm{Hg}^{0}$ emission. More importantly, air-plant interaction increases the complexity of air-terrestrial $\mathrm{Hg}$ exchanges, and the role of vegetation as a source or a sink of atmospheric $\mathrm{Hg}$ has been in debate in the literature. Lindberg et al. (1998) observed a significant $\mathrm{Hg}^{0}$ emission from forest canopies in Tennessee and Sweden (10-300 and 1-4 $\mathrm{ng} \mathrm{m}^{-2} \mathrm{~h}^{-1}$ ). They estimated annual $\mathrm{Hg}^{0}$ emission from global forest to be 800-2000 tons; and emphasized the need for a re-assessment on this potentially important source. Based on the observed $\mathrm{Hg}$ presence in xylem sap (Bishop et al., 1998), plant has been hypothesized as a conduit for releasing geospheric $\mathrm{Hg}$ to the atmosphere (Leonard et al., 1998a, b). Subsequent models simply treated plant emission as a function of evapotranspiration rate (Xu et al., 1999; Bash et al., 2004; Gbor et al., 2006; Shetty et al., 2008). However, more recent measurements suggested that air-surface exchange of $\mathrm{Hg}^{0}$ is largely bidirectional between air and plant and that growing plants act as a net sink (Ericksen et al., 2003; Stamenkovic et al., 2008; Hartman et al., 2009). Stable Hg isotope tracer studies have shown that $\mathrm{Hg}$ in soils cannot be translocated from roots to leaf due to the transport barrier at the root zone (Rutter et al., 2011b; Cui et al., 2014), suggesting that the source of $\mathrm{Hg}$ in the leaf is of atmospheric origin.

$\mathrm{Hg}$ concentration in foliage is generally influenced by the level of ambient air $\mathrm{Hg}^{0}$ (Ericksen et al., 2003; Frescholtz et al., 2003; Ericksen and Gustin, 2004; Millhollen et al., 2006a; Fay and Gustin, 2007a; Niu et al., 2011). Climate factors (e.g., solar irradiation, temperature), biological factors (e.g., leaf age, plant species) and ambient air components (e.g., $\mathrm{CO}_{2}$ ) also significantly influence foliar $\mathrm{Hg}^{0}$ flux (Rea et al., 2002; Millhollen et al., 2006a, b; Fay and Gustin, 2007a; Bushey et al., 2008; Stamenkovic and Gustin, 2009; Rutter et al., 2011a). For instance, the higher Hg concentration found at the bottom aged leaf suggests the influence of longer exposure time (Bushey et al., 2008) over an immediate source from soil (Frescholtz et al., 2003). Stomatal and nonstomatal (e.g., cuticle) processes are both viable pathways for bidirectional Hg exchange (Stamenkovic and Gustin, 2009). Stomatal process may play a predominant role as $\mathrm{Hg}$ accumulated on cuticle surface was generally $<10 \%$ of total $\mathrm{Hg}$ content in the leaf (Rutter et al., 2011a; Laacouri et al., 2013). Solar radiation, temperature and $\mathrm{CO}_{2}$ concentrations regulating plant stomatal activity may therefore affect $\mathrm{Hg}$ uptake and gas exchange. For instance, high air-vegetation $\mathrm{Hg}^{0}$ fluxes observed during daytime show deposition, opposite to daytime evasion observed over other terrestrial surfaces (cf. Sect. 4.3) (Stamenkovic et al., 2008). In addition, leaf $\mathrm{Hg}$ has been shown to be assimilated into leaf biomass during the growing stage (Bash and Miller, 2009), suggesting that $\mathrm{Hg}$ uptake occurs with plant assimilation metabolism.

It has been proposed that leaf $\mathrm{Hg}$ can be classified as two forms: (1) exchangeable $\mathrm{Hg}$ which can be re-emitted back to the atmosphere and (2) biologically assimilated $\mathrm{Hg}$ retained in the leaf (Rutter et al., 2011a). However, whether or not $\mathrm{Hg}^{0}$ can be oxidized after uptake into tissue and the possibility of assimilated $\mathrm{Hg}$ being re-emitted from the leaf (e.g., reduction of leaf retained $\mathrm{Hg}^{\mathrm{II}}$ or un-oxidized $\mathrm{Hg}^{0}$ originally from ambient air) remain unclear. Many studies observed a so-called "compensation point" denoting the interfacial concentration of $\mathrm{Hg}$ that drives the concentration gradient for bidirectional air-vegetation exchange of $\mathrm{Hg}^{0}$ (Hanson et al., 1995; Poissant et al., 2008; Bash and Miller, 2009). However, the hypothesis of a compensation point does not explain the accumulation of $\mathrm{Hg}$ in the vegetation pool. Recent $\mathrm{Hg}$ isotopic fractionation studies show promise for exploring airleaf $\mathrm{Hg}$ exchange mechanisms. Demers et al. (2013) reported a kinetic mass dependent fractionation (MDF,.$\delta^{202} \mathrm{Hg}$ ) of $-2.89 \%$ during air-leaf $\mathrm{Hg}$ exchange from air to leaf. The result indicated that uptake of atmospheric $\mathrm{Hg}$ by the leaf oc- 
curs, and the deposited $\mathrm{Hg}$ is likely to be chemically bonded in the leaf with sulfur and nitrogen functional groups in enzymes within stomatal cavities (Rutter et al., 2011a), rather than with carboxylic ligands on the leaf surface. Another important finding is that negative mass independent fractionation (MIF, $\Delta^{199} \mathrm{Hg}$ ) of $\mathrm{Hg}$ of -0.19 to $-0.29 \%$, correlated well with $\mathrm{Hg}^{\mathrm{II}}$ photochemical reduction by low molecular mass organic matter with sulfur-containing ligands (Zheng and Hintelmann, 2010). This implies that the $\mathrm{Hg}$ re-emission may result from re-volatilization of chemically bounded $\mathrm{Hg}$ in the leaf. However, they did not rule out the potential influence of PBM and GOM that deposit on the leaf, which may undergo partial uptake by the plant with the remaining being re-emitted back to the atmosphere.

\subsection{Air-water Hg exchange}

The bulk methods, DFC and MM methods have been utilized in air-water $\mathrm{Hg}^{0}$ flux measurements. Bulk methods is the most widely utilized approach for the oceanic surface (> $80 \%$ of the field data, Table 1). Sommar et al. (2013a) summarized the methodologies of the bulk method, which is generally controlled by both kinetic (overall mass transfer coefficient, $k$ ) and thermodynamic (partial pressure related concentration gradients) forcing (Wanninkhof, 1992; Wanninkhof et al., 2009; Kuss et al., 2009; Kuss, 2014):

$$
\begin{aligned}
F & =k \times\left(\mathrm{DGM}-\mathrm{GEM} / H_{T}^{\prime}\right) \\
& =0.31 \times U_{10}^{2} \times\left(\frac{v}{600 \times D_{\mathrm{Hg}^{0}}}\right)^{-0.5} \\
& \times\left(\mathrm{DGM}-\mathrm{GEM} / H_{T}^{\prime}\right),
\end{aligned}
$$

where DGM is the dissolved gaseous $\mathrm{Hg}$ concentration in the surface water film, GEM is the near surface gas $\mathrm{Hg}^{0}$ concentration, $H_{T}^{\prime}$ is the dimensions Henry's law constant, $U_{10}$ is the wind speed at $10 \mathrm{~m}, v$ is the water kinematic viscosity, and $D_{\mathrm{Hg}^{0}}$ is the $\mathrm{Hg}^{0}$ diffusion coefficient in water. Figure 5 shows air-surface exchange processes and transformation of DGM in the water phase. From a kinetic point of view, the overall mass transfer coefficient of $\mathrm{Hg}^{0}$ is described by a molecular diffusivity in the water and gas film. Since the mass transfer boundary layer of water has a much greater resistance than the gaseous layer for sparingly soluble $\mathrm{Hg}^{0}$, the overall mass transfer coefficient is limited by the water transfer velocity (Eq. 3) (Kim and Fitzgerald, 1986). Surface wind speed is an important driving force enhancing the mass transfer coefficient in water (Qureshi et al., 2011b), $D_{\mathrm{Hg}^{0}}$ has been experimentally determined as a function of temperature ( $T$, Kelvin) for freshwater $\left(D_{\mathrm{Hg}^{0}}^{\text {fresh }}=0.0335 e^{-18.63 / \mathrm{RT}}, R\right.$ represents gas constant $)$ and seawater $\left(D_{\mathrm{Hg}^{0}}^{\text {sea }}=0.0011 e^{-11.06 / \mathrm{RT}}\right)$ (Kuss, 2014).

Processes controlling the concentration of DGM in surface water directly regulates air-water $\mathrm{Hg}^{0}$ flux. Photochemically induced $\mathrm{Hg}^{\mathrm{II}}$ reduction is the predominant pathway of DGM

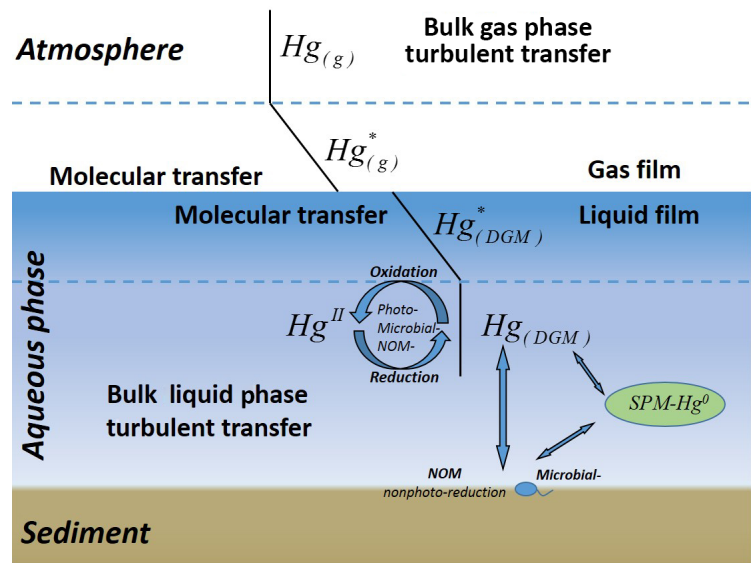

Figure 5. Conceptual view of DGM cycling in water and mass transfer process across the atmosphere-water interface.

formation in surface water (Amyot et al., 1994, 1997a, b; Costa and Liss, 1999; Lalonde et al., 2001; Zhang and Lindberg, 2001; Feng et al., 2004). Zhang (2006) summarized the $\mathrm{Hg}$ photochemical redox chemical process. Equation (4) resembles a simplified scheme of gross photo-reactions governing the DGM pool in surface waters (O'Driscoll et al., 2006, 2008; Qureshi et al., 2010):

$\mathrm{Hg}_{\text {reducible }}+$ photoreductants $\rightleftarrows \mathrm{DGM}+$ photooxidants

$\mathrm{Fe}^{\mathrm{III}}$ has been reported to enhance sunlit photo-reduction in natural water (Lin and Pehkonen, 1997; Zhang and Lindberg, 2001). Complexes of $\mathrm{Fe}^{\mathrm{III}}$-natural organic ligands were hypothesized to undergo photolysis to form reactive intermediates (e.g., organic free radicals) capable of reducing $\mathrm{Hg}^{\mathrm{II}}$. Dissolved organic matter (DOM) serving as electron donor and complexation agent in the natural water is the most important precursor for formation of photo-reductants (Ravichandran, 2004; Vost et al., 2011; Zhang et al., 2011). Similarly, irradiation derived photo-oxidants may oxidize DGM simultaneously and reduce $\mathrm{Hg}$ evasion from water. Reactive radicals (e.g., $\left.\cdot \mathrm{O}_{2}^{-}, \cdot \mathrm{OH}\right)$ produced through DOM, $\mathrm{NO}_{3}^{-}$photolysis have been identified as possible oxidants (Lin and Pehkonen, 1997; Zhang and Lindberg, 2001; Zhang et al., 2012b). In addition, $\mathrm{Cl}^{-}$has been reported to enhance photo-oxidation by stabilizing the oxidative products $\left(\mathrm{HgCl}_{\mathrm{n}}^{2-\mathrm{n}}\right)$ and facilitating oxidation via formation of highly oxidizing ligand $\left(\cdot \mathrm{Cl}_{2}^{-}\right)$(Yamamoto, 1996; Lalonde et al., 2001; Sun et al., 2014). Secondary radicals (e.g., $\mathrm{CO}_{3}^{\bullet-}$ ) can sometimes act as an oxidant (He et al., 2014).

Field studies also observed DGM and $\mathrm{Hg}^{0}$ flux peaks in the nighttime, suggesting the importance of dark reduction (O'Driscoll et al., 2003; Zhang et al., 2006b; Fu et al., 2013b). Both dark abiotic and biotic redox transformations have been suggested to be involved (Fig. 5). Although dark abiotic reduction takes place mainly in the anoxic environment (Gu et al., 2011; Zheng et al., 2012), it also occurs in 
Table 1. A statistical summary of field in situ observed $\mathrm{Hg}^{0}$ flux reported in the literature.

\begin{tabular}{lrrrrrr}
\hline \multirow{2}{*}{ Landscapes } & \multicolumn{3}{c}{$\mathrm{Hg}^{0}$ flux $\left(\mathrm{ng} \mathrm{m}^{-2} \mathrm{~h}^{-1}\right)$} & \multirow{2}{*}{ References $^{\mathrm{b}}$} \\
\cline { 2 - 5 } & Mean & Median & Min $(\mathrm{min})^{\mathrm{a}}$ & $\mathrm{Max}(\max )^{\mathrm{a}}$ & \\
\hline Background soil & 2.1 & 1.3 & $-51.7(-51.7)$ & $33.3(97.8)$ & 159 & $(1)$ \\
Urban settings & 16.4 & 6.2 & $0.2(-318)$ & $129.5(437)$ & 29 & $(2)$ \\
Agricultural fields & 25.1 & 15.3 & $-4.1(-1051)$ & $183(1071)$ & 59 & $(3)$ \\
Forest foliage \& canopy level & 6.3 & 0.7 & $-9.6(-4111)$ & $37.0(1000)$ & 8 & $(4)$ \\
Grasslands & 5.5 & 0.4 & $-18.7(-989.6)$ & $41.5(870)$ & 38 & $(5)$ \\
Wetlands & 12.5 & 1.4 & $-0.3(-375)$ & $85(677)$ & 23 & $(6)$ \\
Freshwater & 4.0 & 2.8 & $-0.3(-18.2)$ & $74.0(88.9)$ & 93 & $(7)$ \\
Sea water & 5.9 & 2.5 & $0.1(-2.7)$ & $40.5(46.0)$ & 51 & $(8)$ \\
Snow & 5.7 & 2.7 & $-10.8(-2160)$ & $40(720)$ & 15 & $(9)$ \\
Natural enriched surfaces & 5618 & 226 & $-5493(-9434)$ & $239200(420000)$ & 329 & $(10)$ \\
Anthropogenically contaminated surfaces & 595 & 184 & $-1.4(-286.2)$ & $13700(13700)$ & 58 & $(11)$ \\
\hline
\end{tabular}

${ }^{a}$ Min/Max are campaign/site-based average flux, while $(\min ) /(\max )$ represent lowest/largest instantaneous flux;

b References:

(1) Schroeder et al. (1989, 2005); Xiao et al. (1991); Kim et al. (1995); Carpi and Lindberg (1998); Ferrara et al. (1998a); Lindberg et al. (1998); Poissant and Casimir (1998); Engle et al. (2001); Zhang et al. (2001); Coolbaugh et al. (2002); Hintelmann et al. (2002); Zehner and Gustin (2002); Fang et al. (2003); Nacht and Gustin (2004); Poissant et al. (2004b); Edwards et al. (2005); Ericksen et al. (2005, 2006); Magarelli and Fostier (2005); Gustin et al. (2006); Sigler and Lee (2006); Wang et al. (2006); Fu et al. (2008a, 2012a, 2016); Kuiken et al. (2008a, b); Almeida et al. (2009); Choi and Holsen (2009a); Kyllonen et al. (2012); Demers et al. (2013); Edwards and Howard (2013); Ma et al. (2013); Slemr et al. (2013); Zhu et al. (2013b); Blackwell et al. (2014); Carpi et al. (2014); Du et al. (2014); (2) Kim and Kim (1999); Fang et al. (2003); Feng et al. (2005); Gabriel et al. (2005, 2006); Obrist et al. (2006); Wang et al. (2006); Eckley and Branfireun (2008); Liu et al. (2014); Osterwalder et al. (2016);

(3) Feng et al. (1997); Carpi and Lindberg (1998); Cobos et al. (2002); Kim et al. (2002, 2003); Wang et al. (2004); Feng et al. (2005); Schroeder et al. (2005); Ericksen et al. (2006); Xin et al. (2006); Cobbett and Van Heyst (2007); Fu et al. (2008a, 2012a); Baya and Van Heyst (2010); Zhu et al. (2011); Sommar et al. (2013b, 2015); Zhu et al. (2013a, 2015b);

(4) Lindberg et al. (1998); Graydon et al. (2006); Bash and Miller (2008, 2009); Poissant et al. (2008); Fu et al. (2016);

(5). Poissant and Casimir (1998); Schroeder et al. (2005); Ericksen et al. (2006); Obrist et al. (2006); Fu et al. (2008a, b); Fritsche et al. (2008b, c); Converse et al. (2010);

(6) Lee et al. (2000); Lindberg and Zhang (2000); Lindberg and Meyers (2001); Lindberg et al. (2002b); Wallschläger et al. (2002); Poissant et al. (2004a, b); Marsik et al. (2005); Schroeder et al. (2005); Zhang et al. (2005, 2006b); Smith and Reinfelder (2009); Kyllonen et al. (2012); Fritsche et al. (2014); Osterwalder et al. (2016); (7) Schroeder et al. (1989, 1992); Xiao et al. (1991); Lindberg et al. (1995b); Amyot et al. (1997a, b); Mason and Sullivan (1997); Poissant and Casimir (1998); Boudala et al. (2000); Poissant et al. (2000); Gårdfeldt et al. (2001); Feng et al. (2002, 2003); O’Driscoll et al. (2003); Feng et al. (2004); Hines and Brezonik (2004); Tseng et al. (2004); Schroeder et al. (2005); Wang et al. (2006); Zhang et al. (2006a); Southworth et al. (2007); O'Driscoll et al. (2007, 2008); Feng et al. (2008b); Fu et al. (2010a, 2013a, b);

(8) Kim and Fitzgerald (1986); Mason and Fitzgerald (1993); Mason et al. (1993, 1998, 1999, 2001); Baeyens and Leermakers (1998); Ferrara and Mazzolai (1998); Ferrara et al. (2001); Gårdfeldt et al. (2001); Rolfhus and Fitzgerald (2001); Wängberg et al. (2001a, b); Feng et al. (2002); Conaway et al. (2003); Gårdfeldt et al. (2003); Laurier et al. (2003); Schroeder et al. (2005); St. Louis et al. (2005); Temme et al. (2005); Narukawa et al. (2006); Andersson et al. (2007); Kuss and Schneider (2007); Sommar et al. (2007); Andersson et al. (2008); Castelle et al. (2009); Fu et al. (2010b); Bouchet et al. (2011); Andersson et al. (2011); Ci et al. (2011a, b, 2015); Xu et al. (2012); Fantozzi et al. (2013); Marumoto and Imai (2015);

(9) Schroeder et al. (2003, 2005); Ferrari et al. (2005); Brooks et al. (2006); Cobbett et al. (2007); Faïn et al. (2007); Sommar et al. (2007); Fritsche et al. (2008c); Steen et al. (2009); Maxwell et al. (2013);

(10) Ferrara et al. (1997, 1998a); Feng et al. (1997); Ferrara and Mazzolai (1998); He et al. (1998); Gustin et al. (1999); Lindberg et al. (1999); Poissant et al. (1999); Wallschläger et al. (1999); Edwards et al. (2001, 2005); Engle et al. (2001); Coolbaugh et al. (2002); Engle and Gustin (2002); Zehner and Gustin (2002); Gustin et al. (2003); Nacht and Gustin (2004); Nacht et al. (2004); Kotnik et al. (2005); Schroeder et al. (2005); Wang et al. (2005, 2007a, b); Engle et al. (2006); García-Sánchez et al. (2006); Eckley et al. (2011a); Edwards and Howard (2013); Fantozzi et al. (2013); Dalziel and Tordon (2014);

(11) Lindberg et al. (1995a); Carpi and Lindberg (1997); Lindberg and Price (1999); Kim et al. (2001); Wängberg et al. (2003); Goodrow et al. (2005); Lindberg et al. (2005); Olofsson et al. (2005); Wang et al. (2006); Xin et al. (2006); Nguyen et al. (2008); Rinklebe et al. (2009); Li et al. (2010); Zhu et al. (2013b); Eckley et al. (2015).

the oxic condition at a lower reaction rate (Allard and Arsenie, 1991). Natural organic matter shows reducing, oxidizing and complexing properties with $\mathrm{Hg}$ in the anoxic environment due to its diversity functional groups (e.g., thiols group, quinones and semiquinone groups, carboxyl group) (Gu et al., 2011; Zheng et al., 2012, 2013). Although aqueous liquid $\mathrm{Hg}$ droplets can be rapidly oxidized in oxygenated chloric water, DGM is unable to be oxidized under such conditions (Amyot et al., 2005).

Biological redox transformation is another important DGM cycling pathway. Ariya et al. (2015) reviewed the biological processes in $\mathrm{Hg}$ redox transformation, which contains phototrophic and chemotrophic $\mathrm{Hg}$ redox processes. Aquatic algae, cyanobacteria and diatoms involved phototrophic $\mathrm{Hg}$ reduction was positively correlated with photosynthetic activities, which is likely a bio-detoxification process (BenBassat and Mayer, 1975; Kuss et al., 2015). In addition, photo-reactivation of DOM and $\mathrm{Fe}^{\mathrm{III}}$ facilitates $\mathrm{Hg}^{\mathrm{II}}$ reduction through algae (Deng et al., 2009). Kuss et al. (2015) reported that cyanobacteria-light synergetic and photochemical transformation equally contributed to $\sim 30 \%$ DGM production in the Baltic Sea, while low-light production contributed $\sim 40 \%$, highlighting the importance of biotic reduction. Two pathways have been identified for $\mathrm{Hg}^{\mathrm{II}}$ reduction by bacteria. The first is reduction by $\mathrm{Hg}$-resistant microorganisms where $\mathrm{Hg}^{\mathrm{II}}$ is reduced in the cell's cytoplasm by mercuric reductase 
and transported out as $\mathrm{Hg}^{0}$ (Barkay et al., 2003); the other is $\mathrm{Hg}^{\mathrm{II}}$ reduced by $\mathrm{Hg}$-sensitive dissimilatory metal-reducing bacteria utilizing iron and/or manganese as a terminal electron acceptor during respiration (Wiatrowski et al., 2006). Intracellular oxidation is supposed to be mediated by oxidase (Siciliano et al., 2002), while extracellular thiol functional groups on cell membrane also show capabilities in oxidizing $\mathrm{Hg}^{0}$ under anoxic environment (Colombo et al., 2013; Hu et al., 2013). A review of genetic-based microbial $\mathrm{Hg}$ redox transformation can be found in Lin et al. (2011).

\subsection{Air-snow Hg exchange}

Schroeder et al. (1998) reported episodes of unexpected low $\mathrm{Hg}^{0}$ concentrations in the Arctic air during spring time, so-called atmospheric mercury depletion events (AMDEs), through an array of photochemically initiated oxidation by halogens (Lindberg et al., 2002a; Sommar et al., 2007; Moore et al., 2014). The phenomena was finally confirmed widespread in the coastal Polar regions. During AMDEs, a large amount of surface layer $\mathrm{Hg}^{0}$ is oxidized and deposited in snowpack via GOM and PBM dry deposition (Steffen et al., 2008). The deposited $\mathrm{Hg}$ onto snow can be rapidly revolatilized back to the atmosphere via photochemical $\mathrm{Hg}^{\mathrm{II}}$ reduction on snow or in melted snow (Dommergue et al., 2003; Faïn et al., 2007; Kirk et al., 2006). Photo-reduction is the predominant pathway for $\mathrm{Hg}$ re-emission from snow as inferred by $\mathrm{Hg}$ isotope fractionation signatures (Sherman et al., 2010). The reduction rate was found to be linearly correlated with UV intensity (Lalonde et al., 2002; Mann et al., $2015 \mathrm{~b}$ ), while $\mathrm{Cl}^{-}$showed an inhibiting effect on the photoreduction (Sect. 3.3) (Steffen et al., 2013). Oxidation and reemission of $\mathrm{Hg}^{0}$ occurred simultaneously with the presence of oxidants (e.g., $\cdot \mathrm{OH}, \cdot \mathrm{Cl}$ and $\cdot \mathrm{Br}$ ) formed through photolysis (Poulain et al., 2004). Nighttime elevated GEM in snow air was observed at Station Nord, Greenland, likely a result from dark formation of reducing radicals (e.g., $\mathrm{HO}_{2} \bullet$ ) (Ferrari et al., 2004). Temperature is another factor enhancing $\mathrm{Hg}$ emission from snow by changing the solid and liquid water ratio (Mann et al., 2015a). $\mathrm{Hg}^{0}$ flux from snow surface in the temperate regions has rarely been investigated (Faïn et al., 2007). Field data collected in Ontario and northern New York confirmed that photo-reduction is the predominant pathway in enhancing $\mathrm{Hg}^{0}$ emission (Lalonde et al., 2003; Maxwell et al., 2013). A positive correlation between $\mathrm{Hg}^{0}$ fluxes and temperature has also been found (Maxwell et al., 2013). $\mathrm{Hg}^{0}$ flux over snow cover under forest canopy was found to be smaller compared to those found in open field, possibly caused by lower light under the canopy (Poulain et al., 2007).

\section{Global observation of atmosphere-biosphere $\mathrm{Hg}$ exchange}

\subsection{Data sources, extraction and processing}

A comprehensive database of global observation of $\mathrm{Hg}^{0}$ flux over terrestrial and oceanic surfaces is compiled from the field-observed data reported in peer-reviewed literature. The fluxes over water surfaces calculated using twofilm gas exchange model based on in-situ measured DGM are also included. For those studies that measured TGM $\left(\mathrm{Hg}^{0}+\mathrm{GOM}\right)$, the measured flux is regarded as $\mathrm{Hg}^{0}$ flux because of the small fraction of GOM in TGM measurement (GOM/GEM < $2 \%$ in general, Gustin and Jaffe, 2010; Sprovieri et al., 2010; Fu et al., 2015b); therefore $\mathrm{Hg}^{0}$ and TGM are not discriminable for $\mathrm{Hg}$ vapor analyzer during a typical concentration measurement period ( $5 \mathrm{~min}$ sampling, $1.0-1.5 \mathrm{~L} \mathrm{~min}^{-1}$ ) in flux sampling. As complete time-series flux data sets are not available in the literature, each data point included in the database corresponds to the arithmetic mean of the flux observed during each campaign, with the campaign period lasting up to 1 year. For those studies that periodically (e.g., weekly) measured seasonal fluxes at the same site, the average flux of all of the campaigns was used. A summary of $\mathrm{Hg}^{0}$ flux data documented in a total of 172 peer reviewed articles are presented in Table 1, which were obtained using the DFCs (85.6\%), MM (7.9\%), $\mathrm{Hg}^{0} /{ }^{222} \mathrm{Rn}$ flux ratio $(0.3 \%)$, and enriched isotope tracers $(0.1 \%)$ methods, or estimated using the two-film gas exchange model $(6.1 \%)$. Based on the landscape characteristics and surface $\mathrm{Hg}$ contents, the flux data sets are assigned to 11 categories. Classification of background soils (e.g., open field bare soil and forest ground soils with little perturbation by human activities) follows the corresponding literature definition. Soil $\mathrm{Hg}$ content of $\leq 0.3 \mu \mathrm{g} \mathrm{g}^{-1}$, which representing terrestrial background level (Agnan et al., 2016), was applied as the threshold for background soil in case no classification was assigned in the original article. $\mathrm{Hg}$ contaminated sites were divided into natural enriched and anthropogenic contaminated sites based on the $\mathrm{Hg}$ sources. The remaining flux data were categorized into 9 classes according to the land uses and ecosystem types (Table 1). It is important to recognize that the $\mathrm{Hg}^{0}$ fluxes represent the experimental and modeling results using diverse methodologies with campaign periods of different durations. Given the reasonably large flux sample sizes, the flux statistics (e.g., mean, median) from multiple studies for different landscapes are compared. It should be noted that the flux reported in laboratory studies and field experiments utilizing treated/untreated substrates are not included in the database. Instead, the implications of those studies are discussed in terms of the environmental effects of $\mathrm{Hg}^{0}$ exchange mechanisms (cf. Sect. 3). 


\subsection{Global database of Earth surfaces-atmosphere $\mathrm{Hg}^{\mathbf{0}}$ flux}

Table 1 summarizes the statistics of $\mathrm{Hg}^{0}$ fluxes measured to date. The site characteristics where $\mathrm{Hg}^{0}$ flux measurements were performed are highly diverse. Most studies were devoted to flux investigations over natural $\mathrm{Hg}$-enriched sites $(\sim 38.2 \%)$ and background surfaces $(\sim 18.4 \%)$. Direct field measurements over terrestrial surfaces accounts for $94.1 \%$ $(n=811)$ of the data; only $5.9 \%(n=51)$ of the data represents oceanic fluxes. In terms of substrate $\mathrm{Hg}$ contents, measurements at contaminated sites (natural $\mathrm{Hg}$-enriched and anthropogenic polluted) consisted of $44.9 \%$ of the data sets, motivated by extensive emission at these sites which may cause local and regional atmospheric pollution. For unpolluted terrestrial surfaces, most measurements were carried out over background soils $(37 \%, n=159)$, while only a few studies directed to the forest foliage and above canopy flux $(n=8)$. DFC methods are suitable for bare soil and low vegetated surface, covering $97 \%$ of the data over background soils. The remaining data sets are observations of ecosystem flux using MM methods, which require relatively more complex instrumentation and experimental efforts in the field (Gustin, 2011; Aubinet et al., 2012; Sommar et al., 2013a).

Figure 6 shows the box and whisker plots of $\mathrm{Hg}^{0}$ fluxes. As seen, the categorized data exhibit substantial data variability and positive skewness. Many campaigns focus only on daytime flux (cf. Sect. 4.3.2) and therefore the median flux in each category is a more appropriate statistic for comparison. The medians of $\mathrm{Hg}^{0}$ fluxes for the 11 site categories follow the following order: grasslands $<$ forest foliage and canopy level $<$ background soils < wetlands < seawater < snow < freshwater < urban settings $<$ agricultural fields $<$ anthropogenically contaminated surfaces $<$ natural Hg-enriched surfaces (Table 1). A clear increase in flux from background to contaminated sites suggests the strong influence of substrate $\mathrm{Hg}$ contents on $\mathrm{Hg}^{0}$ flux. Median fluxes from contaminated sites are 2 orders of magnitude greater than those over other surfaces; such source strength significantly enhances local and regional atmospheric $\mathrm{Hg}$ concentration. Fluxes over vegetative surfaces (grasslands, forest foliage and canopy level), mixed vegetated waters (wetlands) are lower than those over background soils and open water (freshwater and seawater), supporting that vegetation reduces $\mathrm{Hg}$ emission by masking ground floor evasion and/or plant uptake. The fluxes at human perturbed urban settings and over agricultural fields were higher than the fluxes over undisturbed Earth surfaces, likely a result of the re-emission of legacy $\mathrm{Hg}$ deposition. Most surfaces showed $\mathrm{Hg}^{0}$ emission; approximately $25 \%$ of measurements over vegetated surfaces showed net Hg deposition (Fig. 6).

Results of frequency analysis of the mean $\mathrm{Hg}^{0}$ fluxes for each land cover are presented in Fig. 7. While the mean $\mathrm{Hg}^{0}$ flux from background soils have a large range $(-51.7$ to $33.3 \mathrm{ng} \mathrm{m}^{-2} \mathrm{~h}^{-1}$ ), $\sim 90 \%$ of the flux data range from

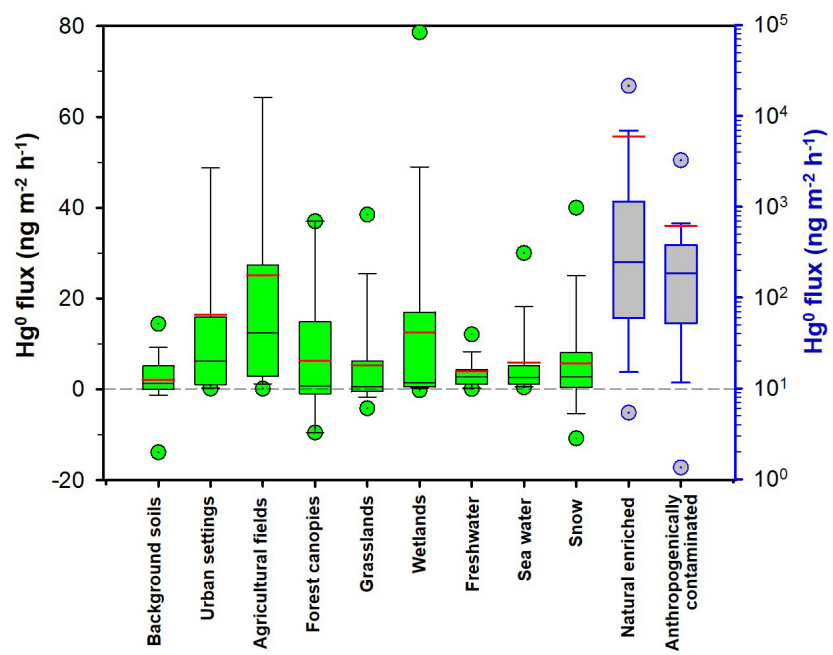

Figure 6. Box and whisker plots of global field-observed $\mathrm{Hg}^{0}$ fluxes obtained from various landscapes. (Data source: Table 1. Red line and black line indicate mean and median flux).

-5 to $10 \mathrm{ng} \mathrm{m}^{-2} \mathrm{~h}^{-1}$. Similar patterns are also evident for freshwater, oceans, grasslands and wetlands. The occasional high emission and deposition fluxes are mainly due to short sampling duration (e.g., mid-day flux) or extreme atmospheric $\mathrm{Hg}^{0}$ concentration events caused by local/regional sources. Comparatively, fluxes over agricultural fields and in urban settings show a much larger range and a lower kurtosis. Strong $\mathrm{Hg}^{0}$ evasion was observed at contaminated sites (> $97 \%$ of total observations showed evasion), although extremely high deposition also occurred in the presence of high ambient $\mathrm{Hg}^{0}$ and atmospheric subsidence (Bash and Miller, 2007; Zhu et al., 2013c). Most measurements over snow ( $87 \%)$ show evasion; these studies were carried out in the Polar regions and focused on $\mathrm{Hg}$ re-emission from snow after AMDEs. The distribution of $\mathrm{Hg}^{0}$ fluxes of air-foliage and canopy level exchange showed that half of the measurements $(n=4)$ give a net emission, while the mean flux is not significantly different from zero ( $p=0.24$, ANOVA).

\subsection{Spatial distribution and temporal variation of global $\mathrm{Hg}^{0}$ flux data}

\subsubsection{Spatial distribution}

Figure 8 shows the box and whisker plots of $\mathrm{Hg}^{0}$ flux from four relatively homogeneous surfaces (background soils, agricultural fields, grasslands and freshwater) observed in different regions. Worldwide fluxes measurements were unevenly distributed, most studies were conducted in North American and East Asia, which limits global representativeness. $\mathrm{Hg}^{0}$ fluxes observed in East Asia are consistently higher compared to those measured in Europe, North and South America, Australia and South Africa $(p<0.05$, ANOVA, except freshwater). This can be explained by the 

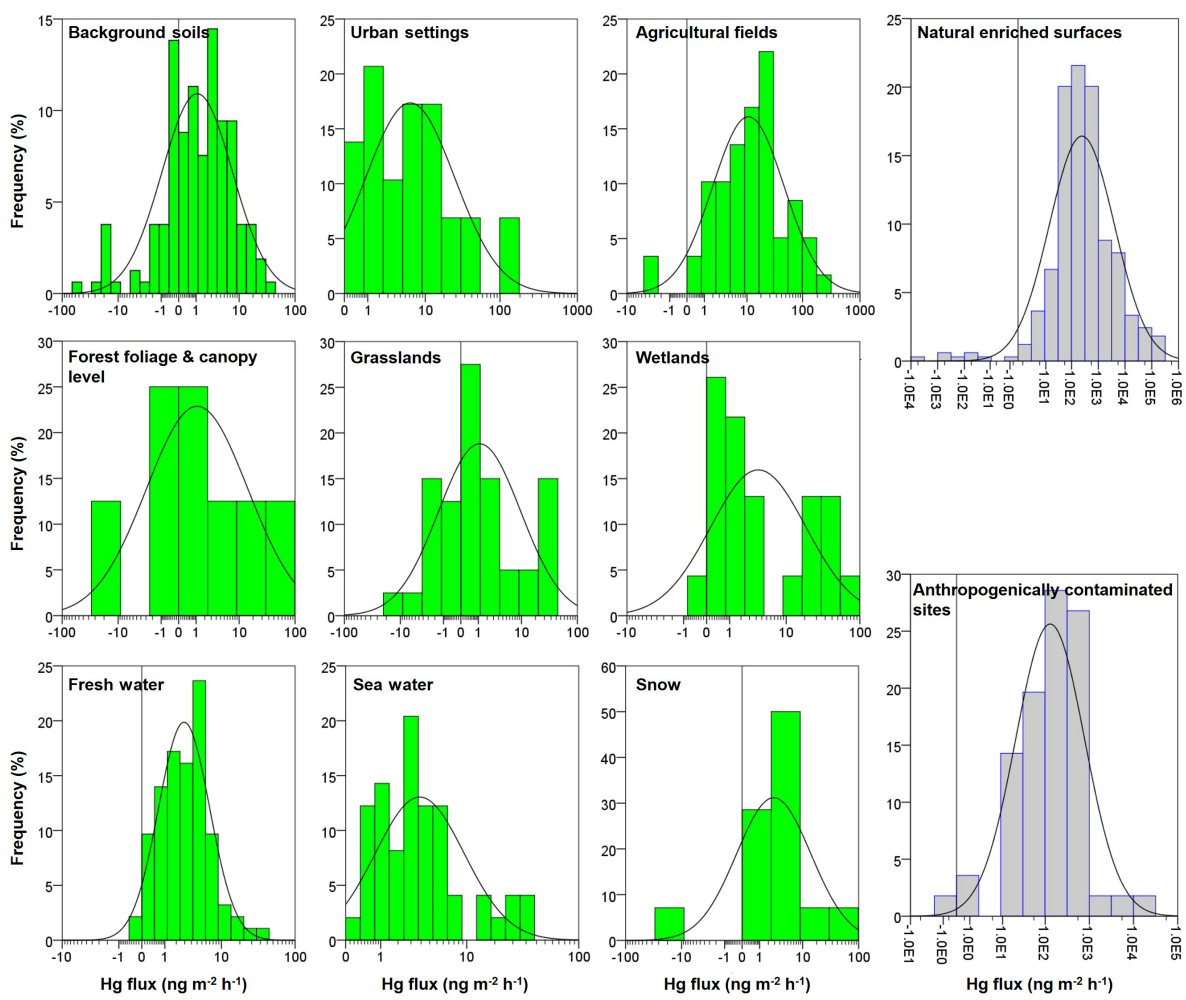

Figure 7. Histograms of $\mathrm{Hg}^{0}$ flux frequency distribution obtained from various Earth surfaces. (Data source: Table 1).

greater anthropogenic emission and re-emission of $\mathrm{Hg}$ deposition (Selin et al., 2007, 2008; Lin et al., 2010b; SmithDowney et al., 2010). The fluxes over freshwater bodies in Europe are somewhat higher than those measured in East Asia (6.5 vs. $4.6 \mathrm{ng} \mathrm{m}^{-2} \mathrm{~h}^{-1}, p=0.40$, ANOVA). These Europe data were obtained mostly prior to $2002(n=9)$ or during summer time and daytime $(n=8)$ (Schroeder et al., 1989; Xiao et al., 1991; Lindberg et al., 1995b; Gårdfeldt et al., 2001; Feng et al., 2002). The earlier measurements were also subject to higher blank and larger extent of photoreduction and evaporation. These complicating factors could have yielded higher fluxes.

\subsubsection{Diurnal and seasonal patterns}

Figure 9 displays the general diel variation of $\mathrm{Hg}^{0}$ fluxes measured by DFC and DFB methods. Fluxes are typically higher during daytime and lower at nighttime from soil, mines, water and snow surfaces, where $\mathrm{Hg}^{0}$ can be formed through photo-reduction. As discussed in Sect. 3, the observed diel variations are in agreement with results from laboratory-controlled studies: higher irradiance and temperature promoted $\mathrm{Hg}^{0}$ reduction and evasion in the daytime, which formed a "dome-shaped" diel flux pattern for most of the Earth surfaces (e.g., soils, mine, water and snow). On the contrary, greater deposition during daytime and evasion/near-zero-flux at nighttime have been frequently observed from foliage, possibly facilitated by the uptake through the stomata that exhibit higher stomatal conductivity during the daytime.

Seasonally, higher evasion flux occurs in the warm season and smaller exchange is observed in the cold season. For example, the seasonal data from Choi and Holsen (2009a) showed a higher evasion from forest floor soil in the Adirondack Mountains (New York, USA) in the summer $\left(1.46 \mathrm{ng} \mathrm{m}^{-2} \mathrm{~h}^{-1}\right)$ shifted to insignificant exchange in the winter $\left(0.19 \mathrm{ng} \mathrm{m}^{-2} \mathrm{~h}^{-1}\right)$. Similar trends were also found in agricultural soils, freshwater and mine surfaces (Fu et al., 2010a; Eckley et al., 2011b; Zhu et al., 2011). However, an opposite low flux in spring and summer was observed in a pristine background deciduous forest floor (Hartman et al., 2009; Kuiken et al., 2008a), which, likely due to drier conditions and lower irradiation, resulted from intense leaf cover. Observed diurnal and seasonal patterns may also be influenced by vegetative surface changes and meteorological characteristics (Bash and Miller, 2009; Fritsche et al., 2008b; Lee et al., 2000; Sommar et al., 2015). For example, Sommar et al. (2015) reported seasonal flux observations over a wheat-corn rotation cropland using REA measurements, an unexpected low flux was observed in the summer during the corn growing stage (median: $-6.1 \mathrm{ng} \mathrm{m}^{-2} \mathrm{~h}^{-1}$ ) due to the uptake by the corn leaf (leaf area index 2.73.6), which is similar to the flux $\left(-6.7 \mathrm{ng} \mathrm{m}^{-2} \mathrm{~h}^{-1}\right)$ observed 

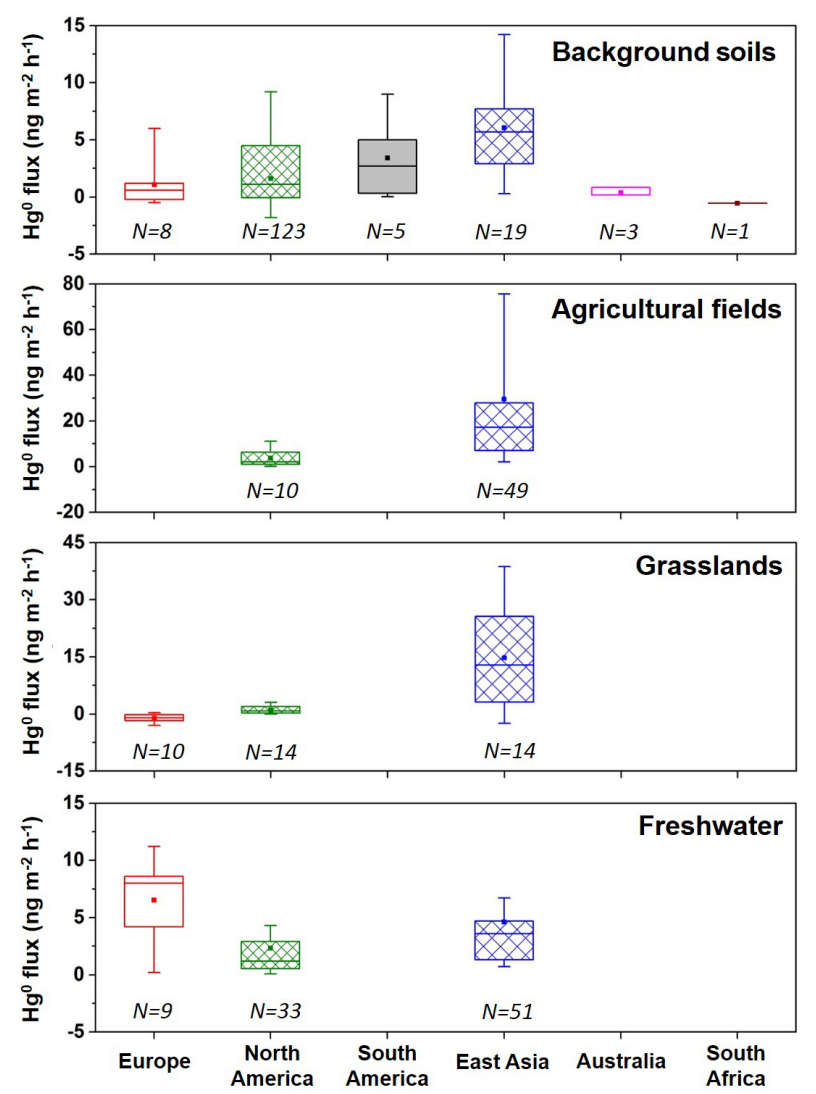

Figure 8. Box and whisker plots of continents segregated $\mathrm{Hg}^{0}$ flux obtained from four homogeneous surfaces (Background soils, agricultural fields, grasslands and freshwater. Filled square block and horizontal line in box indicate mean and median flux).

in the winter and much lower than the wheat canopy flux (13.4 $\mathrm{ng} \mathrm{m}^{-2} \mathrm{~h}^{-1}$ ) in early spring. The limited availability of seasonal data in peer-reviewed literature does not allow a thorough assessment of seasonal characteristics of different terrestrial surfaces. It is important to recognize that the modified landscapes and vegetative biomass growing cycle caused by seasonal changes (e.g., change of LAI in deciduous forest, growing season of forest ecosystem, etc.) may significantly modify the flux characteristics. More data, especially measurements using consistent techniques over a longer campaign period (e.g., 1 year or longer), are needed for addressing the seasonal variability of $\mathrm{Hg}^{0}$ exchange and better estimating the annual exchange from vegetative surfaces. To accomplish such measurements, automation of flux quantification apparatus is also required.

\subsection{Source and sink characteristics of natural surfaces in the context of global $\mathrm{Hg}$ budget}

Based on the findings of the above data synthesis, the implications regarding the role of natural surfaces in modifying global $\mathrm{Hg}$ budget are discussed as followed.

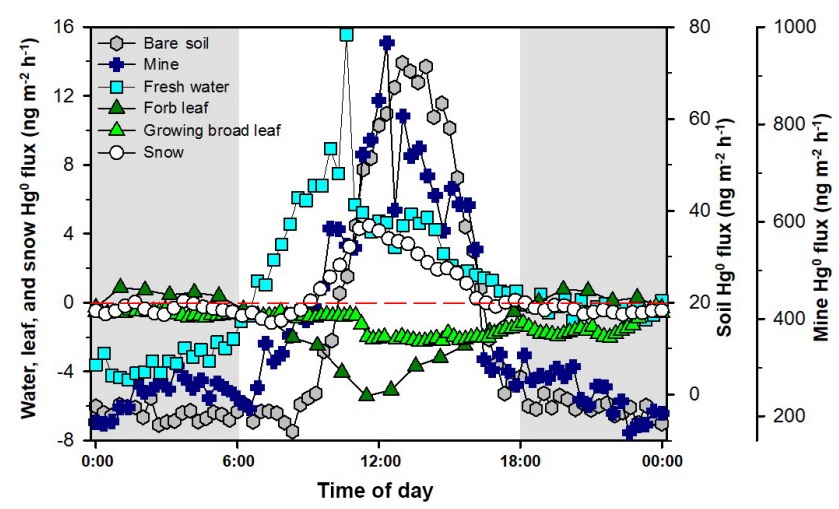

Figure 9. Diurnal patterns of $\mathrm{Hg}^{0}$ flux from various environmental compartments (soil, mine, freshwater, forb leaf, growing broad leaf and snow) measured using DFC methods. (Data obtained from soil: Zhu et al., 2015b; mine: Eckley et al., 2011a; fresh water: O'Driscoll et al., 2003; forb leaf: Stamenkovic et al., 2008; growing broad leaf: Fu et al., 2016; and snow: Maxwell et al., 2013).

\subsubsection{Background soils and water are important diffuse sources of $\mathbf{H g}^{\mathbf{0}}$.}

Although $\mathrm{Hg}^{0}$ flux observed over background soil $\left(1.3 \mathrm{ng} \mathrm{m}^{-2} \mathrm{~h}^{-1}\right)$ and unpolluted water bodies (2.8 and $2.5 \mathrm{ng} \mathrm{m}^{-2} \mathrm{~h}^{-1}$ for fresh and seawater) may appear mild (Table 1), the annual emission from these two types surfaces accounted for $64 \%$ of total atmospheric $\mathrm{Hg}$ emission because of their large areal coverage globally (Pirrone et al., 2010). For example, it has been estimated that bare soil releases $\sim 550 \mathrm{Mg} \mathrm{yr}^{-1}$ (Selin et al., 2008; Pirrone et al., 2010) and surface ocean releases $2000-2900 \mathrm{Mg} \mathrm{yr}^{-1}$ of $\mathrm{Hg}^{\mathrm{O}}$ globally (Fig. 1) (Mason et al., 2012; AMAP/UNEP, 2013). Agnan et al. (2016) projected terrestrial background surfaces flux $\sim 129 \mathrm{Mg} \mathrm{yr}^{-1}$ using compiled laboratory and field measured $\mathrm{Hg}^{0}$ flux; however, the uncertainty various from -829 (37.5th percentile) to 1037 (62.5th percentile) $\mathrm{Mg} \mathrm{yr}^{-1}$. Constraining the uncertainties on $\mathrm{Hg}^{0}$ emission from these diffuse sources will greatly improve the accuracy of the global $\mathrm{Hg}$ budget. Global $\mathrm{Hg}^{0}$ evasion from soil is mainly based on the empirical relationship between flux, temperature and irradiation (cf. Sect. 5), which needs mechanistic refinement. Air-seawater exchange estimated by global models is subject to the uncertainties in (1) mechanisms of aqueous redox transformation and the associated kinetic parameters and (2) $\mathrm{Hg}^{0}$ mass transfer rates as determined by surface fiction velocity (Qureshi et al., 2011a). Kinetic parameters of these processes largely rely on limited field data without experimental verification (AMAP/UNEP, 2013) and require further investigation. Parameterization of $\mathrm{Hg}^{0}$ flux using field data and redox transformation rate constants in soil and water are critical to reduce the uncertainty in future studies. 


\subsubsection{Contaminated surfaces are intensive local $\mathrm{Hg}^{\mathbf{0}}$ sources.}

$\mathrm{Hg}$ evasion from contaminated surfaces (Figs. 6 and 7) has been recognized as an important input contributing to the regional atmospheric $\mathrm{Hg}$ budget (Ferrara et al., 1998b; Kotnik et al., 2005). $\mathrm{Hg}^{0}$ fluxes from contaminated point sources have been extensively investigated by using the LIDAR technique, which is by far the most effective experimental approach to spatially resolve the $\mathrm{Hg}^{0}$ air-surface exchange at contaminated sites. Ferrara et al. (1998a) measured the spatial distribution TGM concentration and TGM flux from the world's largest $\mathrm{Hg}$ mine, the Almadén $\mathrm{Hg}$ mine, in Spain. TGM concentrations and fluxes were estimated to be $0.1-$ $5 \mu \mathrm{g} \mathrm{m}^{-3}$ and $600-1200 \mathrm{~g} \mathrm{~h}^{-1}$ in fall, 1993, above the village of Almadén. Several attempts have been made to quantitatively estimate atmospheric $\mathrm{Hg}$ input in mining areas. Gustin et al. (2003) and Wang et al. (2005) applied a log-linear correlation between the flux and substrate $\mathrm{Hg}$ contents and solar irradiance. Eckley et al. (2011b) computed annual Hg emission from two active gold mines (up to $109 \mathrm{~kg} \mathrm{yr}^{-1}$ ) using flux measurements and statistically derived the empirical relationship between fluxes and meteorological variables based on Geographical Information System (GIS) data. Similarly, Kocman and Horvat (2011) obtained $\sim 51 \mathrm{~kg} \mathrm{yr}^{-1}$ emission from the Idrijca River catchment, a former $\mathrm{Hg}$ mine, using field measurement and GIS data. In total, annual $\mathrm{Hg}$ emission from global contaminated surfaces was estimated to be $\sim 82 \mathrm{Mg}$ via modeling of fluxes from more than $3000 \mathrm{Hg}$ contaminated sites comprising $\mathrm{Hg}$ mining, non-ferrous metal production, precious metal processing and various polluted industrial sites (Kocman et al., 2013), which are emitted from a very limited surface area thus can pose a strong environmental impact to the local area surrounding the contaminated sites.

\subsubsection{Areas impacted by human activities exhibit elevated $\mathrm{Hg}^{\mathbf{0}}$ re-emission.}

The median evasion flux over human urban settings and agricultural fields is 5-10 times higher than the value over background soils (Table 1). Direct anthropogenic $\mathrm{Hg}$ input and atmospheric $\mathrm{Hg}$ deposition explain the enhanced re-emission. Natural surfaces near the anthropogenic point sources (e.g., power plant, $\mathrm{Pb}-\mathrm{Zn}$ smelter, chlor-alkali plant) generally showed higher soil $\mathrm{Hg}$ content due to atmospheric $\mathrm{Hg}$ deposition (Lodenius and Tulisalo, 1984; Li et al., 2011; Zheng et al., 2011; Guédron et al., 2013). A fraction of these deposited $\mathrm{Hg}$ can be swiftly re-emitted back to the atmosphere (Fu et al., 2012a; Eckley et al., 2015). Newly deposited Hg to soil, aquatic systems and snow packs in the Polar regions can also be readily converted to $\mathrm{Hg}^{0}$ and re-emitted (Amyot et al., 2004; Poulain et al., 2004; Ericksen et al., 2005). Eckley et al. (2015) observed soil $\mathrm{Hg}^{0}$ flux near a large basemetal smelter (Flin Flon, Manitoba, Canada) and reported a net deposition during operation $\left(-3.8 \mathrm{ng} \mathrm{m}^{-2} \mathrm{~h}^{-1}\right)$ and elevated emission $\left(108 \mathrm{ng} \mathrm{m}^{-2} \mathrm{~h}^{-1}\right)$ after operation ceased. To date, the source and sink characteristics of surfaces impacted by human activities have not been adequately investigated. Future investigations should be coordinated toward spatially resolving the $\mathrm{Hg}^{0}$ exchange over human impacted surfaces for better quantifying the re-emission budget of legacy $\mathrm{Hg}$.

\subsubsection{Fluxes over vegetated surfaces likely a sink but large uncertainties remain.}

Data of $\mathrm{Hg}^{0}$ fluxes over foliage and forest canopy showed a small net emission (median: $0.7 \mathrm{ng} \mathrm{m}^{-2} \mathrm{~h}^{-1}$ ) with substantial variability (Figs. 6 and 7). Extrapolating the median of database including laboratory flux from leaves, field measured leaves and forest floor flux, Agnan et al. (2016) predicted terrestrial forest act as a net $\mathrm{Hg}^{0}$ sink $\left(-59 \mathrm{Mg} \mathrm{yr}^{-1}\right)$. There have been conflicting reports regarding the role of forest ecosystems as $\mathrm{Hg}$ sources or sinks at global scale (Lindqvist et al., 1991; Lindberg et al., 1998; Frescholtz and Gustin, 2004; Fay and Gustin, 2007a, b; Hartman et al., 2009; Cui et al., 2014). Laboratory studies have suggested that plants are a net sink for atmospheric Hg through leaf assimilation (Millhollen et al., 2006a; Stamenkovic and Gustin, 2009; Rutter et al., 2011b; Cui et al., 2014). Using Hg concentrations in plant tissues and net primary productivity as a proxy for atmospheric $\mathrm{Hg}$ deposition, Obrist (2007) estimated plants remove $\sim 1024.2 \mathrm{Mg} \mathrm{yr}^{-1} \mathrm{Hg}$ globally (foliage contributed $237.6 \mathrm{Mg} \mathrm{yr}^{-1}$ ). Fu et al. (2016) estimated that global litterfall contributes to $1232 \mathrm{Mg} \mathrm{yr}^{-1}$ of $\mathrm{Hg}$ deposition, throughfall contributes to $1338 \mathrm{yr}^{-1}$ of $\mathrm{Hg}$ deposition and the forest floor evades $\sim 381 \mathrm{Mg} \mathrm{yr}^{-1}$ of $\mathrm{Hg}$ into the atmosphere. $\mathrm{Hg}$ content in forest soil is comparatively higher than the concentration found in bare soil due to the input via litterfall and wet $\mathrm{Hg}$ deposition (Blackwell and Driscoll, 2015a, b; Obrist et al., 2011); and $90 \%$ boreal forest soil $\mathrm{Hg}$ was believed to be originated from litterfall input (Jiskra et al., 2015). These studies suggest that the forest ecosystem is likely a large atmospheric $\mathrm{Hg}$ sink, although these bulk proxy methods are not sufficiently sophisticated to resolve the global Hg mass balances. Synchronized, long-term observations of air canopy flux and litterfall/throughfall deposition are useful in helping to understand the source and sink characteristics of forests.

\section{Modeling of air-surface $\mathrm{Hg}^{0}$ exchange flux}

A summary of recent modeling efforts on estimating natural emission is presented in Table 2. For air-foliage $\mathrm{Hg}^{0}$ exchange, earlier parameterizations (S1, Table 2) calculate the flux as a function of the evapotranspiration rate based on soil-root-stem-foliage transpiration stream. It is assumed that $\mathrm{Hg}$ is passed through the soil-root interface and then transferred into foliage in as complexes with organic ligands 
Table 2. A comparison of natural surface mercury flux models.

\begin{tabular}{|c|c|c|c|}
\hline & General models & Description & References \\
\hline \multirow[t]{2}{*}{ Foliage } & $\mathrm{S} 1: F=\mathrm{ECs}$ & $\begin{array}{l}E \text { : transpiration rate }\left(\mathrm{g} \mathrm{m}^{-2} \mathrm{~s}^{-1}\right) \\
\text { Cs: } \mathrm{Hg}^{0} \text { in soil water }\left(\mathrm{ng} \mathrm{g}^{-1}\right)\end{array}$ & $\begin{array}{l}\text { Xu et al. (1999); Bash et al. (2004); } \\
\text { Shetty et al. (2008); Gbor et al. (2006) }\end{array}$ \\
\hline & $\mathrm{S} 2: \quad F_{\mathrm{st} / \mathrm{cu}}=\frac{\chi_{\mathrm{st} / \mathrm{cu}}-\chi_{\mathrm{c}}}{R_{\mathrm{st} / \mathrm{cu}}}$ & $\begin{array}{l}\chi_{\mathrm{st} / \mathrm{cu}}: \text { stomatal/cuticular compensation point }\left(\mathrm{ng} \mathrm{m}^{-3}\right) \\
F_{\mathrm{st} / \mathrm{cu}}: \text { air-cuticular/stomatal flux }\left(\mathrm{ng} \mathrm{m}^{-2} \mathrm{~s}^{-1}\right) \\
\chi_{\mathrm{c}}: \text { compensation point at the air-canopy }\left(\mathrm{ng} \mathrm{m}^{-3}\right) \\
R_{\mathrm{st} / \mathrm{cu}}: \text { resistance between air-cuticular/stomatal }\left(\mathrm{m} \mathrm{s}^{-1}\right)\end{array}$ & $\begin{array}{l}\text { Zhang et al. (2009); } \\
\text { Bash (2010); } \\
\text { Wang et al. (2014); } \\
\text { Wright and Zhang (2015) }\end{array}$ \\
\hline \multirow[t]{3}{*}{ Soil } & $\mathrm{S} 1: \log F=-\frac{\alpha}{T}+\beta \log (C)+\gamma R+\varepsilon$ & $\begin{array}{l}T: \text { soil temperature }\left(^{\circ}\right) \\
C: \text { soil } \mathrm{Hg} \text { concentration }\left(\mathrm{ng} \mathrm{g}^{-1}\right) \\
R: \text { solar radiation }\left(\mathrm{W} \mathrm{m}^{-2}\right)\end{array}$ & $\begin{array}{l}\text { Xu et al. (1999); Bash et al. (2004); } \\
\text { Gbor et al. (2006); Shetty et al. (2008); } \\
\text { Selin et al. (2008) }\end{array}$ \\
\hline & $\mathrm{S} 2: \frac{F}{C}=\alpha T+\beta R+\delta \Theta+\delta T R+\ldots$ & $\begin{array}{l}T: \text { soil temperature }\left(^{\circ}\right) \\
C: \text { soil } \mathrm{Hg} \text { concentration }\left(\mathrm{ng} \mathrm{g}^{-1}\right) \\
R: \text { solar radiation }\left(\mathrm{W} \mathrm{m}^{-2}\right) \\
\Theta: \text { soil moisture }(\%)\end{array}$ & $\begin{array}{l}\text { Lin et al. (2010a); } \\
\text { Kikuchi et al. (2013) }\end{array}$ \\
\hline & $\mathrm{S} 3: F=\frac{\chi_{\mathrm{s}}-\chi_{\mathrm{c}}}{R_{\mathrm{g}}+R_{\mathrm{ac}}}$ & $\begin{array}{l}\chi_{\mathrm{s}}: \text { soil compensation point }\left(\mathrm{ng} \mathrm{m}^{-3}\right) \\
\chi_{\mathrm{c}}: \text { compensation point at the air-soil }\left(\mathrm{ng} \mathrm{m}^{-3}\right) \\
R_{\mathrm{g}}: \text { resistance between air-soil }\left(\mathrm{m} \mathrm{s}^{-1}\right) \\
R_{\mathrm{ac}}: \text { In-canopy aerodynamic resistance }\left(\mathrm{m} \mathrm{s}^{-1}\right)\end{array}$ & $\begin{array}{l}\text { Zhang et al. (2009); } \\
\text { Bash (2010); } \\
\text { Wang et al. (2014) } \\
\text { Wright and Zhang (2015) }\end{array}$ \\
\hline Water & $F=\frac{\chi_{\mathrm{w}}-\chi_{\mathrm{c}}}{R_{\mathrm{w}}+R_{\mathrm{a}}}$ & $\begin{array}{l}\chi_{\mathrm{w}}: \text { water compensation point }\left(\mathrm{ng} \mathrm{m}^{-3}\right) \\
\chi_{\mathrm{c}}: \text { air } \mathrm{Hg}^{0} \text { concentration }\left(\mathrm{ng} \mathrm{m}^{-3}\right) \\
R_{\mathrm{W}}: \text { liquid side resistance }\left(\mathrm{m} \mathrm{s}^{-1}\right) \\
R_{\mathrm{a}}: \text { air side resistance }\left(\mathrm{m} \mathrm{s}^{-1}\right)\end{array}$ & $\begin{array}{l}\text { Xu et al. (1999); Bash et al. (2004); } \\
\text { Gbor et al. (2006), } \\
\text { Shetty et al. (2008); } \\
\text { Bash (2010); Wang et al. (2014) }\end{array}$ \\
\hline
\end{tabular}

(Moreno et al., 2005a, b; Wang et al., 2012). However, root uptake is unlikely to occur (Cui et al., 2014). $\mathrm{Hg}$ isotopic signatures between air and foliage (Demers et al., 2013; Yin et al., 2013) and air-foliage flux measurements (Graydon et al., 2006; Gustin et al., 2008) suggest that (1) the exchange is bidirectional and (2) atmospheric $\mathrm{Hg}$ uptake by foliage is the major pathway for $\mathrm{Hg}$ accumulation. Therefore, a bidirectional flux scheme building on the compensation point (S2, Table 2) is perhaps more scientifically sound and mathematically robust. For air-soil $\mathrm{Hg}^{0}$ exchange, in addition to the bidirectional resistance scheme (S3), statistical relationships have been developed based on measured fluxes and observed environmental factors such as air/soil temperature, solar radiation, soil moisture and soil $\mathrm{Hg}$ content (S1-S2, Table 2), which tends to be site-specific and oversimplifies the influence of environmental factors (Wang et al., 2014). For air-water flux simulations, the two-film diffusion model is widely used by incorporating surface storage and aqueous Hg redox chemistry (Bash et al., 2007; Strode et al., 2007). Bash (2010) suggested a pseudo-first kinetic water photoredox scheme in CMAQ simulations with bidirectional $\mathrm{Hg}$ exchange. Strode et al. (2007) parameterized the reduction rate as the product of local shortwave solar radiation, net primary productivity and a scaling parameter in GEOS-Chem. Soerensen et al. (2010) updated the surface ocean redox reactions in GEOS-Chem, added a term for dark oxidation and suggested linear relationships between the total solar irradiance and net primary productivity, as well as the coefficients of the photo-oxidation rate, photoreduction and biotic reduction.

Using the $\mathrm{S} 1$ scheme (Table 2), the range of simulated airfoliage fluxes are 0 to $5 \mathrm{ng} \mathrm{m}^{-2} \mathrm{~h}^{-1}$ in North America (Bash et al., 2004) and 0 to $80 \mathrm{ng} \mathrm{m}^{-2} \mathrm{~h}^{-1}$ in East Asia (Shetty et al., 2008). Changing the modeling approach to resistancebased models with a compensation point assumption (S2 scheme), the range becomes -2.2 to $-0.7 \mathrm{ng} \mathrm{m}^{-2} \mathrm{~h}^{-1}$ (Wang et al., 2014). Zhang et al. (2012a) reported the annual $\mathrm{Hg}^{0}$ uptake by foliage to be $5-33 \mu \mathrm{g} \mathrm{m}^{-2}$ with the $\mathrm{S} 2$ scheme, similar to the litterfall $\mathrm{Hg}$ flux measured at Mercury Deposition Network sites. For air-soil exchange, model-estimated fluxes ranged from 0 to $25 \mathrm{ng} \mathrm{m}^{-2} \mathrm{~h}^{-1}$ using the $\mathrm{S} 1$ and $\mathrm{S} 2$ scheme (Bash et al., 2004; Gbor et al., 2006; Shetty et al., 2008; Kikuchi et al., 2013), comparable to the $0-20 \mathrm{ng} \mathrm{m}^{-2} \mathrm{~h}^{-1}$ using the S3 scheme (Wang et al., 2014). For air-water exchange, the model-estimated fluxes are $1-12 \mathrm{ng} \mathrm{m}^{-2} \mathrm{~h}^{-1}$ (Bash et al., 2004; Shetty et al., 2008; Bash, 2010; Wang et al., 2014), consistent with measured fluxes (Table 1).

Future development of $\mathrm{Hg}^{0}$ flux models requires mechanistic understanding of air-surface exchange processes. Presently, in the bidirectional resistance scheme, the stomatal compensation point is treated as a constant value (Bash, 2010; Wang et al., 2014) or calculated as following in Wright and Zhang (2015):

$\chi_{\mathrm{st}}=8.204 \frac{8.9803 \times 10^{9}}{T} \cdot \Gamma_{\mathrm{st}} \cdot e^{-\frac{8353.8}{T}}$, 
where $T$ is the temperature of stomata/surface, and $\Gamma_{\mathrm{st}}$ is the emission potential of the stomata. $\Gamma_{\text {st }}$ is an empirical input value and suggested as $5-25 \mathrm{ng} \mathrm{m}^{-3}$ depending on the specific land use. Battke et al. $(2005,2008)$ and Heaton et al. (2005) reported that plants have the ability to reduce the $\mathrm{Hg}^{\mathrm{II}}$ to $\mathrm{Hg}^{0}$ in foliar cells through reducing ligands (e.g., NADPH). To propose a more physically robust modeling scheme, the redox processes in foliage and the role of ligands on $\mathrm{Hg}$ uptake need to be better understood. The finding that $\mathrm{Hg}^{0}$ can pass through the soil-root interface under artificial laboratory conditions (Moreno et al., 2005b) needs to be carefully verified in the field.

Another area that requires advancement is the determination of the $\mathrm{Hg}^{\mathrm{II}}$ reduction rate (Scholtz et al., 2003; Bash, 2010; Wang et al., 2014) and the hypothetical parameter $\Gamma_{\text {st }}$ (Wright and Zhang, 2015) in soil. It is well known that $\mathrm{Hg}^{\text {II }}$ can be reduced by natural organic acids via biotic/abiotic reduction (Zhang and Lindberg, 1999; Zheng et al., 2012). Experimental investigations showed that $\mathrm{O}_{3}$ is important in controlling $\mathrm{Hg}$ emissions from substrates (Engle et al., 2005). However, the kinetic description of these process is fundamentally unknown. The pseudo-first reduction rate constant of $\mathrm{Hg}^{\mathrm{II}}$ has been assumed to be in the range of $10^{-11}$ to $10^{-10} \mathrm{~s}^{-1}$ (Scholtz et al., 2003; Qureshi et al., 2011a). Under laboratory conditions at $100 \mathrm{~W} \mathrm{~m}^{-2}$ and $32 \pm 7^{\circ} \mathrm{C}$, the pseudo-first reduction rate was estimated to be $2-8 \times 10^{-10} \mathrm{~m}^{2} \mathrm{~s}^{-1} \mathrm{w}^{-1}$ basing on $2 \mathrm{~mm}$ soil depth (the maximum depth for light penetration in soil) (Quinones and Carpi, 2011). Si and Ariya (2015) reported a photoreduction rate of $\mathrm{Hg}^{\mathrm{II}}$ in the presence of alkanethiols to be $3-$ $9 \times 10^{-9} \mathrm{~m}^{2} \mathrm{~s}^{-1} \mathrm{w}^{-1}$. Other than these kinetic information, kinetic measurements for $\mathrm{Hg}^{\mathrm{II}}$ reduction in the absence of light will enable additional mechanistic parameterization of $\mathrm{Hg}$ evasion models for soil and vegetative surfaces.

\section{Conclusions and future perspectives}

Understanding the air-surface exchange of $\mathrm{Hg}^{0}$ has been steadily advancing since the mid-1980s. A substantial amount of data exists, but with large uncertainty and data gaps in Africa, South and Central Asia, Middle East, South America and Australia. Fundamentally, flux measurement approaches (e.g., MM and DFCs) are different and individual flux measurement data are not directly comparable. The $\mathrm{Hg}^{0}$ flux data compiled in this study represent the current state of understanding that requires continuous updates. $\mathrm{Hg}^{0}$ fluxes in East Asia are statistically higher than the values observed in other world regions, suggesting re-emission of atmospheric deposition or a strong anthropogenic influence. $\mathrm{Hg}^{0}$ exchange over weak diffuse sources (e.g., background soil and water) and vegetation need better constraints for global analysis of the atmospheric Hg budget through extensive on-site measurements and fundamental mechanical studies (e.g., redox transformation rate constant, mass transfer diffusivity). Although predominate factors controlling $\mathrm{Hg}^{0}$ fluxes have been identified, the effects of those factors on flux have not been fundamentally and quantitatively determined for different surfaces, which limits the accuracy of flux modeling. Based on the synthesis in this study, the following knowledge gaps need to be addressed:

1. Improving the temporal resolution and sensitivity of $\mathrm{Hg}^{0}$ flux measurements. Insufficient temporal resolution and sensitivity in the detection of ambient $\mathrm{Hg}$ have limited our capability in accurately determining the airsurface exchange of $\mathrm{Hg}^{0}$. Development of high temporal resolution and sensitive sensors for determining $\mathrm{Hg}^{0}$ concentration gradients is of prime importance in improving flux data quality and in reducing uncertainties in the global assessment of the $\mathrm{Hg}$ budget. Such advancement will also open up new opportunities to explore fundamental exchange mechanism in response to the changes in environmental factors.

2. Standardization of $\mathrm{Hg}^{0}$ flux measurement techniques and establishment of a data comparison strategy. $\mathrm{Hg}^{0}$ flux measurement uncertainties from using different techniques remains large, a standardized method is useful to compare fluxes obtained from various techniques. Fundamental studies are needed to compare contemporary $\mathrm{Hg}^{0}$ flux quantification methods. Experimental approaches that synchronize the measured fluxes by different methods are also suggested in order to build empirical database for method inter-comparisons. Achieving this will largely reduce the uncertainty in the $\mathrm{Hg}$ budget estimation and greatly improve comparability of flux data reported by different research groups.

3. Fundamental investigation on the environmental processes driving $\mathrm{Hg}$ exchange. Although flux responses to environmental parameters (e.g., irradiance, precipitation, temperature rising) are qualitatively defined in a statistical sense, the processes driving $\mathrm{Hg}^{0}$ exchange need to be understood fundamentally. Recent advancement on isotopic tracing techniques (e.g., enriched $\mathrm{Hg}$ isotope tracers and stable $\mathrm{Hg}$ isotopic fractionation data) may offer mechanistic insights and new data should be incorporated into modeling analyses.

4. Long-term measurement of $\mathrm{Hg}^{0}$ fluxes at representative sites. There is a substantial data gap in the current $\mathrm{Hg}^{0}$ flux database in terms of geographical coverage and land use type. Forests are most likely an overlooked sink for atmospheric $\mathrm{Hg}^{0}$. However, few field campaigns have been conducted at forest sites. In addition, current flux databases are mainly obtained from short-term campaigns. It is unclear how global changes (e.g., climate change, global $\mathrm{Hg}$ emission reduction from anthropogenic sources) will force $\mathrm{Hg}^{0}$ flux changes over different surfaces. There is presently no network of 
fluxes measurements at global monitoring sites. Continuous observation of flux is useful for providing a more comprehensive database for scale-up estimation.

5. Development and improvement of air-surface exchange models for $\mathrm{Hg}$. The present state of development of air-surface exchange models does not allow appropriate process analysis due to a lack of fundamental understanding in the chemical and mass transfer processes of evasion and deposition. Existing air-surface $\mathrm{Hg}^{0}$ flux schemes incorporate over-simplified chemical schemes with not-yet verified kinetic parameters. In addition, the interactions between $\mathrm{Hg}^{\mathrm{II}}$ and organic matters in the natural environment, as well as the interfacial transfer of different $\mathrm{Hg}$ species over various surfaces, have significant knowledge gaps. Studies addressing these gaps are critically needed and will benefit not only the measurement approaches but also the model parameterization for estimating the global air-surface exchange of $\mathrm{Hg}$.

Acknowledgements. This research was supported by 973 Program (2013CB430002) and the National Science Foundation of China (41503122, 41428301).

Edited by: L. Zhang

\section{References}

Agnan, Y., Le Dantec, T., Moore, C. W., Edwards, G. C., and Obrist, D.: New constraints on terrestrial surface-atmosphere fluxes of gaseous elemental mercury using a global database, Environ. Sci. Technol., 50, 507-524, 2016.

Aldén, M., Edner, H., and Svanberg, S.: Remote measurement of atmospheric mercury using differential absorption lidar, Opt. Lett., 7, 221-223, 1982.

Allard, B. and Arsenie, I.: Abiotic reduction of mercury by humic substances in aquatic system - an important process for the mercury cycle, Water Air Soil Poll., 56, 457-464, 1991.

Almeida, M. D., Marins, R. V., Paraquetti, H. H. M., Bastos, W. R., and Lacerda, L. D.: Mercury degassing from forested and open field soils in Rondonia, Western Amazon, Brazil, Chemosphere, 77, 60-66, 2009.

AMAP/UNEP: Technical Background Report for the Global Mercury Assessment 2013, Arctic Monitoring and Assessment Programme, Oslo, Norway/UNEP Chemicals Branch, Geneva, Switzerland, 1-263, 2013.

Amyot, M., Mierle, G., Lean, D. R. S., and Mcqueen, D. J.: Sunlight-induced formation of dissolved gaseous mercury in lake waters, Environ. Sci. Technol., 28, 2366-2371, 1994.

Amyot, M., Lean, D., and Mierle, G.: Photochemical formation of volatile mercury in high Arctic lakes, Environ. Toxicol. Chem., 16, 2054-2063, 1997a.

Amyot, M., Mierle, G., Lean, D., and McQueen, D. J.: Effect of solar radiation on the formation of dissolved gaseous mercury in temperate lakes, Geochim. Cosmochim. Ac., 61, 975-987, $1997 b$.

Amyot, M., Southworth, G., Lindberg, S. E., Hintelmann, H., Lalonde, J. D., Ogrinc, N., Poulain, A. J., and Sandilands, K. A.: Formation and evasion of dissolved gaseous mercury in large enclosures amended with ${ }^{200} \mathrm{HgCl}_{2}$, Atmos. Environ., 38, 4279 4289, 2004.

Amyot, M., Morel, F. M. M., and Ariya, P. A.: Dark oxidation of dissolved and liquid elemental mercury in aquatic environments, Environ. Sci. Technol., 39, 110-114, 2005.

Andersson, M. E., Gårdfeldt, K., Wängberg, I., Sprovieri, F., Pirrone, N., and Lindqvist, O.: Seasonal and daily variation of mercury evasion at coastal and off shore sites from the Mediterranean Sea, Mar. Chem., 104, 214-226, 2007.

Andersson, M. E., Sommar, J., Gårdfeldt, K., and Lindqvist, O.: Enhanced concentrations of dissolved gaseous mercury in the surface waters of the Arctic Ocean, Mar. Chem., 110, 190-194, 2008.

Andersson, M. E., Sommar, J., Gårdfeldt, K., and Jutterstrom, S.: Air-sea exchange of volatile mercury in the North Atlantic Ocean, Mar. Chem., 125, 1-7, 2011.

Ariya, P. A., Amyot, M., Dastoor, A., Deeds, D., Feinberg, A., Kos, G., Poulain, A., Ryjkov, A., Semeniuk, K., Subir, M., and Toyota, K.: Mercury physicochemical and biogeochemical transformation in the atmosphere and at atmospheric interfaces: a review and future directions, Chem. Rev., 115, 3760-3802, 2015.

Aubinet, M., Vesala, T., and Papale, D.: Eddy covariance: a practical guide to measurement and data analysis, Dordrecht, the Netherlands, Springer, 1-424, 2012.

Baeyens, W. and Leermakers, M.: Elemental mercury concentrations and formation rates in the Scheldt estuary and the North Sea, Mar. Chem., 60, 257-266, 1998.

Bahlmann, E., Ebinghaus, R., and Ruck, W.: Development and application of a laboratory flux measurement system (LFMS) for the investigation of the kinetics of mercury emissions from soils, J. Environ. Manage., 81, 114-125, 2006.

Barkay, T., Miller, S. M., and Summers, A. O.: Bacterial mercury resistance from atoms to ecosystems, FEMS Microbiol. Rev., 27, 355-384, 2003.

Bash, J. O.: Description and initial simulation of a dynamic bidirectional air-surface exchange model for mercury in Community Multiscale Air Quality (CMAQ) model, J. Geophys. Res.Atmos., 115, D06305, doi:10.1029/2009JD012834, 2010.

Bash, J. O. and Miller, D. R.: A note on elevated total gaseous mercury concentrations downwind from an agriculture field during tilling, Sci. Total Environ., 388, 379-388, 2007.

Bash, J. O. and Miller, D. R.: A relaxed eddy accumulation system for measuring surface fluxes of total gaseous mercury, J. Atmos. Ocean. Tech., 25, 244-257, 2008.

Bash, J. O. and Miller, D. R.: Growing season total gaseous mercury (TGM) flux measurements over an Acer rubrum L. stand, Atmos. Environ., 43, 5953-5961, 2009.

Bash, J. O., Miller, D. R., Meyer, T. H., and Bresnahan, P. A.: Northeast United States and Southeast Canada natural mercury emissions estimated with a surface emission model, Atmos. Environ., 38, 5683-5692, 2004.

Bash, J. O., Bresnahan, P., and Miller, D. R.: Dynamic surface interface exchanges of mercury: A review and compartmentalized 
modeling framework, J. Appl. Meteorol. Clim., 46, 1606-1618, 2007.

Battke, F., Ernst, D., and Halbach, S.: Ascorbate promotes emission of mercury vapour from plants, Plant Cell Environ., 28, 14871495, 2005.

Battke, F., Ernst, D., Fleischmann, F., and Halbach, S.: Phytoreduction and volatilization of mercury by ascorbate in Arabidopsis thaliana, European beech and Norway spruce, Appl. Geochem., 23, 494-502, 2008.

Bauer, D., Campuzano-Jost, P., and Hynes, A. J.: Rapid, ultrasensitive detection of gas phase elemental mercury under atmospheric conditions using sequential two-photon laser induced fluorescence, J. Environ. Monitor., 4, 339-343, 2002.

Bauer, D., Everhart, S., Remeika, J., Tatum Ernest, C., and Hynes, A. J.: Deployment of a sequential two-photon laser-induced fluorescence sensor for the detection of gaseous elemental mercury at ambient levels: fast, specific, ultrasensitive detection with partsper-quadrillion sensitivity, Atmos. Meas. Tech., 7, 4251-4265, doi:10.5194/amt-7-4251-2014, 2014.

Baya, A. P. and Van Heyst, B.: Assessing the trends and effects of environmental parameters on the behaviour of mercury in the lower atmosphere over cropped land over four seasons, Atmos. Chem. Phys., 10, 8617-8628, doi:10.5194/acp-10-86172010, 2010.

Ben-Bassat, D. and Mayer, A. M.: Volatilization of Mercury by Algae, Physiol. Plant., 33, 128-132, 1975.

Beverland, I. J., Oneill, D. H., Scott, S. L., and Moncrieff, J. B.: Design, construction and operation of flux measurement systems using the conditional sampling technique, Atmos. Environ., 30, 3209-3220, 1996.

Bishop, K. H., Lee, Y. H., Munthe, J., and Dambrine, E.: Xylem sap as a pathway for total mercury and methylmercury transport from soils to tree canopy in the boreal forest, Biogeochemistry, 40, 101-113, 1998.

Blackwell, B. D. and Driscoll, C. T.: Deposition of Mercury in Forests along a Montane Elevation Gradient, Environ. Sci. Technol., 49, 5363-5370, 2015a.

Blackwell, B. D. and Driscoll, C. T.: Using foliar and forest floor mercury concentrations to assess spatial patterns of mercury deposition, Environ. Poll., 202, 126-134, 2015 b.

Blackwell, B., Driscoll, C., Maxwell, J., and Holsen, T.: Changing climate alters inputs and pathways of mercury deposition to forested ecosystems, Biogeochemistry, 119, 215-228, 2014.

Bouchet, S., Tessier, E., Monperrus, M., Bridou, R., Clavier, J., Thouzeau, G., and Amouroux, D.: Measurements of gaseous mercury exchanges at the sediment-water, water-atmosphere and sediment-atmosphere interfaces of a tidal environment (Arcachon Bay, France), J. Environ. Monitor., 13, 1351-1359, 2011.

Boudala, F. S., Folkins, I., Beauchamp, S., Tordon, R., Neima, J., and Johnson, B.: Mercury Flux Measurements over Air and Water in Kejimkujik National Park, Nova Scotia, Water Air Soil Poll., 122, 183-202, 2000.

Brooks, S. B., Saiz-Lopez, A., Skov, H., Lindberg, S. E., Plane, J. M. C., and Goodsite, M. E.: The mass balance of mercury in the springtime arctic environment, Geophys. Res. Lett., 33, L13812, doi:10.1029/2005GL025525, 2006.

Bushey, J. T., Nallana, A. G., Montesdeoca, M. R., and Driscoll, C. T.: Mercury dynamics of a northern hardwood canopy, Atmos. Environ., 42, 6905-6914, 2008.
Carpi, A. and Lindberg, S. E.: Sunlight-mediated emission of elemental mercury from soil amended with municipal sewage sludge, Environ. Sci. Technol., 31, 2085-2091, 1997.

Carpi, A. and Lindberg, S. E.: Application of a Teflon (TM) dynamic flux chamber for quantifying soil mercury flux: Tests and results over background soil, Atmos. Environ., 32, 873-882, 1998.

Carpi, A., Frei, A., Cocris, D., McCloskey, R., Contreras, E., and Ferguson, K.: Analytical artifacts produced by a polycarbonate chamber compared to a Teflon chamber for measuring surface mercury fluxes, Anal. Bioanal. Chem., 388, 361-365, 2007.

Carpi, A., Fostier, A. H., Orta, O. R., dos Santos, J. C., and Gittings, M.: Gaseous mercury emissions from soil following forest loss and land use changes: Field experiments in the United States and Brazil, Atmos. Environ., 96, 423-429, 2014.

Castelle, S., Schäfer, J., Blanc, G., Dabrin, A., Lanceleur, L., and Masson, M.: Gaseous mercury at the air-water interface of a highly turbid estuary (Gironde Estuary, France), Mar. Chem., 117, 42-51, 2009.

Choi, H. D. and Holsen, T. M.: Gaseous mercury fluxes from the forest floor of the Adirondacks, Environ. Poll., 157, 592-600, 2009a.

Choi, H. D. and Holsen, T. M.: Gaseous mercury emissions from unsterilized and sterilized soils: The effect of temperature and UV radiation, Environ. Poll., 157, 1673-1678, 2009 b.

Ci, Z., Wang, C., Wang, Z., and Zhang, X.: Elemental mercury $(\mathrm{Hg}(0))$ in air and surface waters of the Yellow Sea during late spring and late fall 2012: Concentration, spatial-temporal distribution and air/sea flux, Chemosphere, 119, 199-208, 2015.

Ci, Z. J., Zhang, X. S., and Wang, Z. W.: Elemental mercury in coastal seawater of Yellow Sea, China: Temporal variation and air-sea exchange, Atmos. Environ., 45, 183-190, $2011 \mathrm{a}$.

Ci, Z. J., Zhang, X. S., Wang, Z. W., Niu, Z. C., Diao, X. Y., and Wang, S. W.: Distribution and air-sea exchange of mercury $(\mathrm{Hg})$ in the Yellow Sea, Atmos. Chem. Phys., 11, 2881-2892, doi:10.5194/acp-11-2881-2011, 2011 b.

Clarkson, T. W. and Magos, L.: The toxicology of mercury and its chemical compounds, Crit. Rev. Toxicol., 36, 609-662, 2006.

Cobbett, F. D. and Van Heyst, B. J.: Measurements of GEM fluxes and atmospheric mercury concentrations (GEM, RGM and $\mathrm{Hg}$ $\mathrm{P})$ from an agricultural field amended with biosolids in Southern Ont., Canada (October 2004-November 2004), Atmos. Environ., 41, 2270-2282, 2007.

Cobbett, F. D., Steffen, A., Lawson, G., and Van Heyst, B. J.: GEM fluxes and atmospheric mercury concentrations (GEM, RGM and Hg-P) in the Canadian Arctic at Alert, Nunavut, Canada (February-June 2005), Atmos. Environ., 41, 6527-6543, 2007.

Cobos, D. R., Baker, J. M., and Nater, E. A.: Conditional sampling for measuring mercury vapor fluxes, Atmos. Environ., 36, 43094321, 2002.

Colombo, M. J., Ha, J., Reinfelder, J. R., Barkay, T., and Yee, N.: Anaerobic oxidation of $\mathrm{Hg}(0)$ and methylmercury formation by Desulfovibrio desulfuricans ND132, Geochim. Cosmochim. Ac., 112, 166-177, 2013.

Conaway, C. H., Squire, S., Mason, R. P., and Flegal, A. R.: Mercury speciation in the San Francisco Bay estuary, Mar. Chem., 80, 199-225, 2003. 
Converse, A. D., Riscassi, A. L., and Scanlon, T. M.: Seasonal variability in gaseous mercury fluxes measured in a high-elevation meadow, Atmos. Environ., 44, 2176-2185, 2010.

Coolbaugh, M. F., Gustin, M. S., and Rytuba, J. J.: Annual emissions of mercury to the atmosphere from natural sources in Nevada and California, Environ. Geol., 42, 338-349, 2002.

Corbett-Hains, H., Walters, N. E., and Van Heyst, B. J.: Evaluating the effects of sub-zero temperature cycling on mercury flux from soils, Atmos. Environ., 102, 102-108, 2012.

Corbitt, E. S., Jacob, D. J., Holmes, C. D., Streets, D. G., and Sunderland, E. M.: Global source-receptor relationships for mercury deposition under present-day and 2050 emissions scenarios, Environ. Sci. Technol., 45, 10477-10484, 2011.

Costa, M. and Liss, P. S.: Photoreduction of mercury in sea water and its possible implications for $\mathrm{Hg}-0$ air-sea fluxes, Mar. Chem., 68, 87-95, 1999.

Cui, L., Feng, X., Lin, C.-J., Wang, X., Meng, B., Wang, X., and Wang, H.: Accumulation and translocation of ${ }^{198} \mathrm{Hg}$ in four crop species, Environ. Toxicol. Chem., 33, 334-340, 2014.

Dalziel, J. and Tordon, R.: Gaseous mercury flux measurements from two mine tailing sites in the Seal Harbour area of Nova Scotia, Geochem. Explor. Env. A., 14, 17-24, 2014.

Demers, J. D., Blum, J. D., and Zak, D. R.: Mercury isotopes in a forested ecosystem: Implications for air-surface exchange dynamics and the global mercury cycle, Global Biogeochem. Cy., 27, 222-238, 2013.

Deng, L., Fu, D., and Deng, N.: Photo-induced transformations of mercury(II) species in the presence of algae, Chlorella vulgaris, J. Hazard. Mater., 164, 798-805, 2009.

Dommergue, A., Ferrari, C. P., Gauchard, P.-A., Boutron, C. F., Poissant, L., Pilote, M., Jitaru, P., and Adams, F. C.: The fate of mercury species in a sub-arctic snowpack during snowmelt, Geophys. Res. Lett., 30, 1621, doi:10.1029/2003GL017308, 2003.

Driscoll, C. T., Mason, R. P., Chan, H. M., Jacob, D. J., and Pirrone, N.: Mercury as a global pollutant: Sources, pathways, and effects, Environ. Sci. Technol., 47, 4967-4983, 2013.

Du, B., Wang, Q., Luo, Y., and Duan, L.: Field measurements of soil $\mathrm{Hg}$ emission in a masson pine forest in Tieshanping, Chongqing in Southwestern China, Huanjing Kexue, 10, 35, 3830-3835, 2014 (in Chinese with English Abstract).

Eckley, C. S. and Branfireun, B.: Gaseous mercury emissions from urban surfaces: Controls and spatiotemporal trends, Appl. Geochem., 23, 369-383, 2008.

Eckley, C. S., Gustin, M., Lin, C. J., Li, X., and Miller, M. B.: The influence of dynamic chamber design and operating parameters on calculated surface-to-air mercury fluxes, Atmos. Environ., 44, 194-203, 2010.

Eckley, C. S., Gustin, M., Marsik, F., and Miller, M. B.: Measurement of surface mercury fluxes at active industrial gold mines in Nevada (USA), Sci. Total Environ., 409, 514-522, 2011 a.

Eckley, C. S., Gustin, M., Miller, M. B., and Marsik, F.: Scaling non-point-source mercury emissions from two active industrial gold mines: Influential Variables and Annual Emission Estimates, Environ. Sci. Technol., 45, 392-399, 2011 b.

Eckley, C. S., Blanchard, P., McLennan, D., Mintz, R., and Sekela, M.: Soil-air mercury flux near a large industrial emission source before and after Closure (Flin Flon, Manitoba, Canada), Environ. Sci. Technol., 49, 9750-9757, 2015.
Edner, H., Faris, G., Sunesson, A., Svanberg, S., Bjarnason, J. Ö., Kristmannsdottir, H., and Sigurdsson, K.: Lidar search for atmospheric atomic mercury in Icelandic geothermal fields, J. Geophys. Res.-Atmos., 96, 2977-2986, 1991.

Edwards, G. C. and Howard, D. A.: Air-surface exchange measurements of gaseous elemental mercury over naturally enriched and background terrestrial landscapes in Australia, Atmos. Chem. Phys., 13, 5325-5336, doi:10.5194/acp-13-5325-2013, 2013.

Edwards, G. C., Rasmussen, P. E., Schroeder, W. H., Kemp, R. J., Dias, G. M., Fitzgerald-Hubble, C. R., Wong, E. K., HalfpennyMitchell, L., and Gustin, M. S.: Sources of variability in mercury flux measurements, J. Geophys. Res.-Atmos., 106, 5421-5435, 2001.

Edwards, G. C., Rasmussen, P. E., Schroeder, W. H., Wallace, D. M., Halfpenny-Mitchell, L., Dias, G. M., Kemp, R. J., and Ausma, S.: Development and evaluation of a sampling system to determine gaseous mercury fluxes using an aerodynamic micrometeorological gradient method, J. Geophys. Res.-Atmos., 110, D10306, doi:10.1029/2004jd005187, 2005.

Engle, M. A. and Gustin, M. S.: Scaling of atmospheric mercury emissions from three naturally enriched areas: Flowery Peak, Nevada; Peavine Peak, Nevada; and Long Valley Caldera, California, Sci. Total Environ., 290, 91-104, 2002.

Engle, M. A., Gustin, M. S., and Zhang, H.: Quantifying natural source mercury emissions from the Ivanhoe Mining District, north-central Nevada, USA, Atmos. Environ., 35, 3987-3997, 2001.

Engle, M. A., Gustin, M. S., Lindberg, S. E., Gertler, A. W., and Ariya, P. A.: The influence of ozone on atmospheric emissions of gaseous elemental mercury and reactive gaseous mercury from substrates, Atmos. Environ., 39, 7506-7517, 2005.

Engle, M. A., Gustin, M. S., Goff, F., Counce, D. A., Janik, C. J., Bergfeld, D., and Rytuba, J. J.: Atmospheric mercury emissions from substrates and fumaroles associated with three hydrothermal systems in the western United States, J. Geophys. Res.-Atmos., 111, D17304, doi:10.1029/2005JD006563, 2006.

Ericksen, J. A. and Gustin, M. S.: Foliar exchange of mercury as a function of soil and air mercury concentrations, Sci. Total Environ., 324, 271-279, 2004.

Ericksen, J. A., Gustin, M. S., Schorran, D. E., Johnson, D. W., Lindberg, S. E., and Coleman, J. S.: Accumulation of atmospheric mercury in forest foliage, Atmos. Environ., 37, 16131622, 2003.

Ericksen, J. A., Gustin, M. S., Lindberg, S. E., Olund, S. D., and Krabbenhoft, D. P.: Assessing the potential for re-emission of mercury deposited in precipitation from arid soils using a stable isotope, Environ. Sci. Technol., 39, 8001-8007, 2005.

Ericksen, J. A., Gustin, M. S., Xin, M., Weisberg, P. J., and Femandez, G. C. J.: Air-soil exchange of mercury from background soils in the United States, Sci. Total Environ., 366, 851-863, 2006.

Faïn, X., Grangeon, S., Bahlmann, E., Fritsche, J., Obrist, D., Dommergue, A., Ferrari, C. P., Cairns, W., Ebinghaus, R., and Barbante, C.: Diurnal production of gaseous mercury in the alpine snowpack before snowmelt, J. Geophys. Res.-Atmos., 112, D21311, doi:10.1029/2007JD008520, 2007.

Faïn, X., Moosmüller, H., and Obrist, D.: Toward real-time measurement of atmospheric mercury concentrations using cavity 
ring-down spectroscopy, Atmos. Chem. Phys., 10, 2879-2892, doi:10.5194/acp-10-2879-2010, 2010.

Fang, F., Wang, Q., and Luo, J.: Mercury concentration, emission flux in urban land surface and its factors, Shengtai Huanjing, 12, 260-262, 2003 (in Chinese with English Abstract).

Fantozzi, L., Ferrara, R., Dini, F., Tamburello, L., Pirrone, N., and Sprovieri, F.: Study on the reduction of atmospheric mercury emissions from mine waste enriched soils through native grass cover in the Mt. Amiata region of Italy, Environ. Res., 125, 6974, 2013.

Fay, L. and Gustin, M.: Assessing the influence of different atmospheric and soil mercury concentrations on foliar mercury concentrations in a controlled environment, Water Air Soil Poll., 181, 373-384, 2007a.

Fay, L. and Gustin, M. S.: Investigation of mercury accumulation in cattails growing in constructed wetland mesocosms, Wetlands, 27, 1056-1065, 2007b.

Feng, X., Chen, Y., and Zhu, W.: Vertical fluxes of volatile mercury over soil surfaces in Guizhou Province, China, J. Environ. Sci., 9, 241-245, 1997.

Feng, X., Shang, L., Tang, S., Yan, H., and Liu, C.: Gaseous mercury exchange rate between air and water over Baihua reservoir, Guizhou, China during cold season, J. Phys. Iv, 107, 451-454, 2003.

Feng, X. B., Sommar, J., Gårdfeldt, K., and Lindqvist, O.: Exchange flux of total gaseous mercury between air and natural water surfaces in summer season, Sci. China Ser. D, 45, 211-220, 2002.

Feng, X. B., Yan, H. Y., Wang, S. F., Qiu, G. L., Tang, S. L., Shang, L. H., Dai, Q. J., and Hou, Y. M.: Seasonal variation of gaseous mercury exchange rate between air and water surface over Baihua reservoir, Guizhou, China, Atmos. Environ., 38, 4721-4732, 2004.

Feng, X. B., Wang, S. F., Qiu, G. L., Hou, Y. M., and Tang, S. L.: Total gaseous mercury emissions from soil in Guiyang, Guizhou, China, J. Geophys. Res.-Atmos., 110, D14306, doi:10.1029/2004JD005643, 2005.

Feng, X. B., Li, P., Qiu, G. L., Wang, S., Li, G. H., Shang, L. H., Meng, B., Jiang, H. M., Bai, W. Y., Li, Z. G., and Fu, X. W.: Human exposure to methylmercury through rice intake in mercury mining areas, guizhou province, china, Environ. Sci. Technol., 42, 326-332, 2008a.

Feng, X. B., Wang, S. F., Qiu, G. G., He, T. R., Li, G. H., Li, Z. G., and Shang, L. H.: Total gaseous mercury exchange between water and air during cloudy weather conditions over Hongfeng Reservoir, Guizhou, China, J. Geophys. Res.-Atmos., 113, D15309, doi:10.1029/2007JD009600, 2008b.

Ferrara, R. and Mazzolai, B.: A dynamic flux chamber to measure mercury emission from aquatic systems, Sci. Total Environ., 215, 51-57, 1998.

Ferrara, R., Maserti, B. E., Andersson, M., Edner, H., Ragnarson, P., and Svanberg, S.: Mercury degassing rate from mineralized areas in the Mediterranean basin, Water Air Soil Poll., 93, 5966, 1997.

Ferrara, R., Maserti, B. E., Andersson, M., Edner, H., Ragnarson, P., Svanberg, S., and Hernandez, A.: Atmospheric mercury concentrations and fluxes in the Almadén district (Spain), Atmos. Environ., 32, 3897-3904, 1998a.
Ferrara, R., Mazzolai, B., Edner, H., Svanberg, S., and Wallinder, E.: Atmospheric mercury sources in the Mt. Amiata area, Italy, Sci. Total Environ., 213, 13-23, 1998b.

Ferrara, R., Lanzillotta, E., and Ceccarini, C.: Dissolved gaseous mercury concentration and mercury evasional flux from seawater in front of a chlor-alkali plant, Environ. Technol., 22, 971-978, 2001.

Ferrari, C. P., Dommergue, A., Boutron, C. F., Skov, H., Goodsite, M., and Jensen, B.: Nighttime production of elemental gaseous mercury in interstitial air of snow at Station Nord, Greenland, Atmos. Environ., 38, 2727-2735, 2004.

Ferrari, C. P., Gauchard, P. A., Aspmo, K., Dommergue, A., Magand, O., Bahlmann, E., Nagorski, S., Temme, C., Ebinghaus, R., and Steffen, A.: Snow-to-air exchanges of mercury in an Arctic seasonal snow pack in Ny-Ålesund, Svalbard, Atmos. Environ., 39, 7633-7645, 2005.

Fitzgerald, W. F. and Gill, G. A.: Subnanogram determination of mercury by two-stage gold amalgamation and gas phase detection applied to atmospheric analysis, Anal. Chem., 51, 17141720, 1979.

Frescholtz, T. F., Gustin, M. S., Schorran, D. E., and Fernandez, G. C. J.: Assessing the source of mercury in foliar tissue of quaking aspen, Environ. Toxicol. Chem., 22, 2114-2119, 2003.

Frescholtz, T. F. and Gustin, M. S.: Soil and foliar mercury emission as a function of soil concentration, Water Air Soil Poll., 155, 223-237, 2004.

Fritsche, J., Obrist, D., and Alewell, C.: Evidence of microbial control of $\mathrm{Hg}^{0}$ emissions from uncontaminated terrestrial soils, J. Plant Nutr. Soil Sc., 171, 200-209, 2008a.

Fritsche, J., Obrist, D., Zeeman, M. J., Conen, F., Eugster, W., and Alewell, C.: Elemental mercury fluxes over a sub-alpine grassland determined with two micrometeorological methods, Atmos. Environ., 42, 2922-2933, 2008 b.

Fritsche, J., Wohlfahrt, G., Ammann, C., Zeeman, M., Hammerle, A., Obrist, D., and Alewell, C.: Summertime elemental mercury exchange of temperate grasslands on an ecosystem-scale, Atmos. Chem. Phys., 8, 7709-7722, doi:10.5194/acp-8-7709-2008, 2008c.

Fritsche, J., Osterwalder, S., Nilsson, M. B., Sagerfors, J., Åkerblom, S., Bishop, K., and Alewell, C.: Evasion of Elemental Mercury from a Boreal Peatland Suppressed by Long-Term Sulfate Addition, Environ. Sci. Technol. Lett., 1, 421-425, 2014.

Fu, X., Feng, X., Zhang, H., Yu, B., and Chen, L.: Mercury emissions from natural surfaces highly impacted by human activities in Guangzhou province, South China, Atmos. Environ., 54, 185193, 2012a.

Fu, X. W., Feng, X., Liang, P., Deliger, Zhang, H., Ji, J., and Liu, P.: Temporal trend and sources of speciated atmospheric mercury at Waliguan GAW station, Northwestern China, Atmos. Chem. Phys., 12, 1951-1964, 2012b.

Fu, X., Feng, X., Guo, Y., Meng, B., Yin, R., and Yao, H.: Distribution and production of reactive mercury and dissolved gaseous mercury in surface waters and water/air mercury flux in reservoirs on Wujiang River, Southwest China, J. Geophys. Res.Atmos., 118, 3905-3917, $2013 \mathrm{a}$.

Fu, X., Feng, X., Yin, R., and Zhang, H.: Diurnal variations of total mercury, reactive mercury, and dissolved gaseous mercury concentrations and water/air mercury flux in warm and cold sea- 
sons from freshwaters of southwestern China, Environ. Toxicol. Chem., 32, 2256-2265, 2013b.

Fu, X. W., Feng, X. B., and Wang, S. F.: Exchange fluxes of $\mathrm{Hg}$ between surfaces and atmosphere in the eastern flank of Mount Gongga, Sichuan province, southwestern China, J. Geophys. Res.-Atmos., 113, D20306, doi:10.1029/2008JD009814, 2008 a.

Fu, X. W., Feng, X. B., Wang, S. F., Qiu, G. L., and Li, P.: Mercury flux rate of two types of grasslands in Guiyang, Huanjing Kexue Yanjiu, 20, 33-37, 2008b (in Chinese with English Abstract).

Fu, X. W., Feng, X. B., Wan, Q., Meng, B., Yan, H. Y., and Guo, Y. N.: Probing Hg evasion from surface waters of two Chinese hyper/meso-eutrophic reservoirs, Sci. Total Environ., 408, 58875896, 2010a.

Fu, X. W., Feng, X. B., Zhang, G., Xu, W. H., Li, X. D., Yao, H., Liang, P., Li, J., Sommar, J., Yin, R. S., and Liu, N.: Mercury in the marine boundary layer and seawater of the South China Sea: Concentrations, sea/air flux, and implication for land outflow, J. Geophys. Res.-Atmos., 115, D06303, doi:10.1029/2009JD012958, 2010b.

Fu, X. W., Zhang, H., Lin, C.-J., Feng, X. B., Zhou, L. X., and Fang, S. X.: Correlation slopes of GEM / CO, GEM / $\mathrm{CO}_{2}$, and $\mathrm{GEM} / \mathrm{CH}_{4}$ and estimated mercury emissions in China, South Asia, the Indochinese Peninsula, and Central Asia derived from observations in northwestern and southwestern China, Atmos. Chem. Phys., 15, 1013-1028, doi:10.5194/acp-15-1013-2015, 2015a.

Fu, X. W., Zhang, H., Yu, B., Wang, X., Lin, C.-J., and Feng, X. B.: Observations of atmospheric mercury in China: a critical review, Atmos. Chem. Phys., 15, 9455-9476, doi:10.5194/acp-15-94552015, 2015b.

Fu, X. W., Zhu, W., Zhang, H., Wang, X., Sommar, J., Yang, X., Lin, C. J., and Feng, X. B.: Depletion of atmospheric gaseous elemental mercury by plant uptake at Mt. Changbai, Northeast China, Unpublished Data, 2016.

Gabriel, M. C., Williamson, D. G., Brooks, S., Zhang, H., and Lindberg, S.: Spatial variability of mercury emissions from soils in a southeastern US urban environment, Environ. Geol., 48, 955964, 2005

Gabriel, M. C., Williamson, D. G., Zhang, H., Brooks, S., and Lindberg, S.: Diurnal and seasonal trends in total gaseous mercury flux from three urban ground surfaces, Atmos. Environ., 40, 4269-4284, 2006.

García-Sánchez, A., Contreras, F., Adams, M., and Santos, F.: Atmospheric mercury emissions from polluted gold mining areas (Venezuela), Environ. Geochem. Hlth., 28, 529-540, 2006.

Gårdfeldt, K., Feng, X., Sommar, J., and Lindqvist, O.: Total gaseous mercury exchange between air and water at river and sea surfaces in Swedish coastal regions, Atmos. Environ., 35, 30273038, 2001.

Gårdfeldt, K., Sommar, J., Ferrara, R., Ceccarini, C., Lanzillotta, E., Munthe, J., Wängberg, I., Lindqvist, O., Pirrone, N., Sprovieri, F., Pesenti, E., and Strömberg, D.: Evasion of mercury from coastal and open waters of the Atlantic Ocean and the Mediterranean Sea, Atmos. Environ., 37, 73-84, 2003.

Gbor, P., Wen, D., Meng, F., Yang, F., Zhang, B., and Sloan, J.: Improved model for mercury emission, transport and deposition, Atmos. Environ., 40, 973-983, 2006.
Gillis, A. and Miller, D. R.: Some potential errors in the measurement of mercury gas exchange at the soil surface using a dynamic flux chamber, Sci. Total Environ., 260, 181-189, 2000a.

Gillis, A. A. and Miller, D. R.: Some local environmental effects on mercury emission and absorption at a soil surface, Sci. Total Environ., 260, 191-200, 2000b.

Goodrow, S. M., Miskewitz, R., Hires, R. I., Eisenreich, S. J., Douglas, W. S., and Reinfelder, J. R.: Mercury emissions from cement-stabilized dredged material, Environ. Sci. Technol., 39, 8185-8190, 2005.

Graydon, J. A., St Louis, V. L., Lindberg, S. E., Hintelmann, H., and Krabbenhoft, D. P.: Investigation of mercury exchange between forest canopy vegetation and the atmosphere using a new dynamic chamber, Environ. Sci. Technol., 40, 4680-4688, 2006.

Grigal, D. F.: Mercury sequestration in forests and peatlands: A review, J. Environ. Qual., 32, 393-405, 2003.

Gronholm, T., Haapanala, S., Launiainen, S., Rinne, J., Vesala, T., and Rannik, U.: The dependence of the beta coefficient of REA system with dynamic deadband on atmospheric conditions, Environ. Poll., 152, 597-603, 2008.

Gu, B. H., Bian, Y. R., Miller, C. L., Dong, W. M., Jiang, X., and Liang, L. Y.: Mercury reduction and complexation by natural organic matter in anoxic environments, P. Natl. Acad. Sci. USA, 108, 1479-1483, 2011.

Guédron, S., Grangeon, S., Jouravel, G., Charlet, L., and Sarret, G.: Atmospheric mercury incorporation in soils of an area impacted by a chlor-alkali plant (Grenoble, France): Contribution of canopy uptake, Sci. Total Environ., 445, 356-364, 2013.

Gustin, M. S.: Exchange of mercury between the atmosphere and terrestrial ecosystems, in: Environmental Chemistry and Toxicology of Mercury, edited by: Liu, G. L., Cai, Y., and O'Driscoll, N., 423-451, 2011.

Gustin, M. and Jaffe, D.: Reducing the Uncertainty in Measurement and Understanding of Mercury in the Atmosphere, Environ. Sci. Technol., 44, 2222-2227, 2010.

Gustin, M. S. and Stamenkovic, J.: Effect of watering and soil moisture on mercury emissions from soils, Biogeochemistry, 76, 215232, 2005.

Gustin, M. S., Taylor, G. E., and Maxey, R. A.: Effect of temperature and air movement on the flux of elemental mercury from substrate to the atmosphere, J. Geophys. Res.-Atmos., 102, 38913898, 1997.

Gustin, M. S., Lindberg, S., Marsik, F., Casimir, A., Ebinghaus, R., Edwards, G., Hubble-Fitzgerald, C., Kemp, R., Kock, H., Leonard, T., London, J., Majewski, M., Montecinos, C., Owens, J., Pilote, M., Poissant, L., Rasmussen, P., Schaedlich, F., Schneeberger, D., Schroeder, W., Sommar, J., Turner, R., Vette, A., Wallschlaeger, D., Xiao, Z., and Zhang, H.: Nevada STORMS project: Measurement of mercury emissions from naturally enriched surfaces, J. Geophys. Res.-Atmos., 104, 21831 21844, 1999.

Gustin, M. S., Biester, H., and Kim, C. S.: Investigation of the light-enhanced emission of mercury from naturally enriched substrates, Atmos. Environ., 36, 3241-3254, 2002.

Gustin, M. S., Coolbaugh, M. F., Engle, M. A., Fitzgerald, B. C., Keislar, R. E., Lindberg, S. E., Nacht, D. M., Quashnick, J., Rytuba, J. J., Sladek, C., Zhang, H., and Zehner, R. E.: Atmospheric mercury emissions from mine wastes and surrounding geologically enriched terrains, Environ. Geol., 43, 339-351, 2003. 
Gustin, M. S., Ericksen, J. A., Schorran, D. E., Johnson, D. W., Lindberg, S. E., and Coleman, J. S.: Application of controlled mesocosms for understanding mercury air-soil-plant exchange, Environ. Sci. Technol., 38, 6044-6050, 2004.

Gustin, M. S., Engle, M., Ericksen, J., Lyman, S., Stamenkovic, J., and Xin, M.: Mercury exchange between the atmosphere and low mercury containing substrates, Appl. Geochem., 21, 1913-1923, 2006.

Gustin, M. S., Lindberg, S. E., and Weisberg, P. J.: An update on the natural sources and sinks of atmospheric mercury, Appl. Geochem., 23, 482-493, 2008.

Gustin, M. S., Huang, J., Miller, M. B., Peterson, C., Jaffe, D. A., Ambrose, J., Finley, B. D., Lyman, S. N., Call, K., Talbot, R., Feddersen, D., Mao, H., and Lindberg, S. E.: Do we understand what the mercury speciation instruments are actually measuring? Results of RAMIX, Environ. Sci. Technol., 47, 7295-7306, 2013.

Gustin, M. S., Amos, H. M., Huang, J., Miller, M. B., and Heidecorn, K.: Measuring and modeling mercury in the atmosphere: a critical review, Atmos. Chem. Phys., 15, 5697-5713, doi:10.5194/acp-15-5697-2015, 2015.

Hanson, P. J., Lindberg, S. E., Tabberer, T. A., Owens, J. G., and Kim, K. H.: Foliar exchange of mercury-vapor - evidence for a compensation point, Water Air Soil Poll., 80, 373-382, 1995.

Hartman, J. S., Weisberg, P. J., Pillai, R., Ericksen, J. A., Kuiken, T., Lindberg, S. E., Zhang, H., Rytuba, J. J., and Gustin, M. S.: Application of a rule-based model to estimate mercury exchange for three background biomes in the Continental United States, Environ. Sci. Technol., 43, 4989-4994, 2009.

He, F., Zhao, W., Liang, L., and Gu, B.: Photochemical oxidation of dissolved elemental mercury by carbonate radicals in water, Environ. Sci. Technol. Lett., 1, 499-503, 2014.

He, J., Tan, H., Sommar, J., Xiao, Z., and Lindqvist, O.: Mercury pollution in a mining area of Guizhou, China: Fluxes over contaminated surfaces and concentrations in air, biological and geological samples, Toxicol. Environ. Chem., 67, 225-236, 1998.

Heaton, A. P., Rugh, C., Wang, N.-J., and Meagher, R.: Physiological responses of transgenic merA-tobacco (Nicotiana tabacum) to foliar and root mercury exposure, Water Air Soil Poll., 161, 137-155, 2005.

Hines, N. A. and Brezonik, P. L.: Mercury dynamics in a small Northern Minnesota lake: water to air exchange and photoreactions of mercury, Mar. Chem., 90, 137-149, 2004.

Hintelmann, H., Harris, R., Heyes, A., Hurley, J. P., Kelly, C. A., Krabbenhoft, D. P., Lindberg, S., Rudd, J. W. M., Scott, K. J., and St Louis, V. L.: Reactivity and mobility of new and old mercury deposition in a Boreal forest ecosystem during the first year of the METAALICUS study, Environ. Sci. Technol., 36, 5034-5040, 2002.

Holland, K.: Standard operation procedures: Ohio lumex mercury analyzer (Lumex RA 915), available at: http://www.renewnyc. com/content/pdfs/130liberty/SeptemberDeconstruction/B_ SOP_for_OhioLumex.pdf (last access: 25 March 2016), 2005.

Hu, H., Lin, H., Zheng, W., Tomanicek, S. J., Johs, A., Feng, X., Elias, D. A., Liang, L., and Gu, B.: Oxidation and methylation of dissolved elemental mercury by anaerobic bacteria, Nat. Geosci., 6, 751-754, 2013.

Jaffe, D., Prestbo, E., Swartzendruber, P., Weiss-Penzias, P., Kato, S., Takami, A., Hatakeyama, S., and Kajii, Y.: Export of atmo- spheric mercury from Asia, Atmos. Environ., 39, 3029-3038, 2005.

Jiskra, M., Wiederhold, J. G., Skyllberg, U., Kronberg, R.-M., Hajdas, I., and Kretzschmar, R.: Mercury deposition and re-emission pathways in boreal forest soils investigated with $\mathrm{Hg}$ isotope signatures, Environ. Sci. Technol., 49, 7188-7196, 2015.

Kikuchi, T., Ikemoto, H., Takahashi, K., Hasome, H., and Ueda, H.: Parameterizing soil emission and atmospheric oxidationreduction in a model of the global biogeochemical cycle of mercury, Environ. Sci. Technol., 47, 12266-12274, 2013.

Kim, J. P. and Fitzgerald, W. F.: Sea-air partitioning of mercury in the Equatorial Pacific Ocean, Science, 231, 1131-1133, 1986.

Kim, K. H. and Kim, M. Y.: The exchange of gaseous mercury across soil-air interface in a residential area of Seoul, Korea, Atmos. Environ., 33, 3153-3165, 1999.

Kim, K. H. and Lindberg, S. E.: Design and initial tests of a dynamic enclosure chamber for measurements of vapor-phase mercury fluxes over soils, Water Air Soil Poll., 80, 1059-1068, 1995.

Kim, K. H., Lindberg, S. E., and Meyers, T. P.: Micrometeorological measurements of mercury-vapor fluxes over background forest soils in eastern Tennessee, Atmos. Environ., 29, 267-282, 1995.

Kim, K. H., Kim, M. Y., and Lee, G.: The soil-air exchange characteristics of total gaseous mercury from a large-scale municipal landfill area, Atmos. Environ., 35, 3475-3493, 2001.

Kim, K.-H., Kim, M.-Y., Kim, J., and Lee, G.: The concentrations and fluxes of total gaseous mercury in a western coastal area of Korea during late March 2001, Atmos. Environ., 36, 3413-3427, 2002.

Kim, K. H., Kim, M. Y., Kim, J., and Lee, G.: Effects of changes in environmental conditions on atmospheric mercury exchange: Comparative analysis from a rice paddy field during the two spring periods of 2001 and 2002, J. Geophys. Res.-Atmos., 108, 4607, doi:10.1029/2003JD003375, 2003.

Kirk, J. L., St. Louis, V. L., and Sharp, M. J.: Rapid reduction and reemission of mercury deposited into snowpacks during atmospheric mercury depletion events at Churchill, Manitoba, Canada, Environ. Sci. Technol., 40, 7590-7596, 2006.

Kocman, D. and Horvat, M.: A laboratory based experimental study of mercury emission from contaminated soils in the River Idrijca catchment, Atmos. Chem. Phys., 10, 1417-1426, doi:10.5194/acp-10-1417-2010, 2010.

Kocman, D. and Horvat, M.: Non-point source mercury emission from the Idrija Hg-mine region: GIS mercury emission model, J. Environ. Manage., 92, 2038-2046, 2011.

Kocman, D., Horvat, M., Pirrone, N., and Cinnirella, S.: Contribution of contaminated sites to the global mercury budget, Environ. Res., 125, 160-170, 2013.

Kotnik, J., Horvat, M., and Dizdarevic, T.: Current and past mercury distribution in air over the Idrija $\mathrm{Hg}$ mine region, Slovenia, Atmos. Environ., 39, 7570-7579, 2005.

Kuiken, T., Zhang, H., Gustin, M., and Lindberg, S.: Mercury emission from terrestrial background surfaces in the eastern USA Part I: Air/surface exchange of mercury within a southeastern deciduous forest (Tennessee) over one year, Appl. Geochem., 23, 345-355, 2008a.

Kuiken, T., Gustin, M., Zhang, H., Lindberg, S., and Sedinger, B.: Mercury emission from terrestrial background surfaces in the eastern USA. II: Air/surface exchange of mercury within forests 
from South Carolina to New England, Appl. Geochem., 23, 356368, 2008b.

Kuss, J.: Water-air gas exchange of elemental mercury: An experimentally determined mercury diffusion coefficient for $\mathrm{Hg}^{0}$ water-air flux calculations, Limnol. Oceanogr., 59, 1461-1467, 2014

Kuss, J. and Schneider, B.: Variability of the gaseous elemental mercury sea-air flux of the Baltic Sea, Environ. Sci. Technol., 41, 8018-8023, 2007.

Kuss, J., Holzmann, J., and Ludwig, R.: An elemental mercury diffusion coefficient for natural waters determined by molecular dynamics simulation, Environ. Sci. Technol., 43, 3183-3186, 2009.

Kuss, J., Wasmund, N., Nausch, G., and Labrenz, M.: Mercury Emission by the Baltic Sea: A consequence of cyanobacterial activity, photochemistry, and low-light mercury Transformation, Environ. Sci. Technol., 49, 11449-11457, 2015.

Kyllonen, K., Hakola, H., Hellen, H., Korhonen, M., and Verta, M.: Atmospheric mercury fluxes in a southern boreal forest and wetland, Water Air Soil Poll., 223, 1171-1182, 2012.

Laacouri, A., Nater, E. A., and Kolka, R. K.: Distribution and uptake dynamics of mercury in leaves of common deciduous tree species in Minnesota, U.S.A, Environ. Sci. Technol., 47, 10462-10470, 2013.

Lalonde, J. D., Amyot, M., Kraepiel, A. M. L., and Morel, F. M. M.: Photooxidation of $\mathrm{Hg}(0)$ in artificial and natural waters, Environ. Sci. Technol., 35, 1367-1372, 2001.

Lalonde, J. D., Poulain, A. J., and Amyot, M.: The role of mercury redox reactions in snow on snow-to-air mercury transfer, Environ. Sci. Technol., 36, 174-178, 2002.

Lalonde, J. D., Amyot, M., Doyon, M.-R., and Auclair, J.-C.: Photoinduced $\mathrm{Hg}(\mathrm{II})$ reduction in snow from the remote and temperate Experimental Lakes Area (Ontario, Canada), J. Geophys. Res.Atmos., 108, 4200, doi:10.1029/2001JD001534, 2003.

Laurier, F. J. G., Mason, R. P., Whalin, L., and Kato, S.: Reactive gaseous mercury formation in the North Pacific Ocean's marine boundary layer: A potential role of halogen chemistry, J. Geophys. Res.-Atmos., 108, 4529, doi:10.1029/2003JD003625, 2003.

Lee, X., Benoit, G., and Hu, X. Z.: Total gaseous mercury concentration and flux over a coastal saltmarsh vegetation in Connecticut, USA, Atmos. Environ., 34, 4205-4213, 2000.

Leonard, T. L., Taylor, G. E., Gustin, M. S., and Fernandez, G. C. J.: Mercury and plants in contaminated soils: 1 . Uptake, partitioning, and emission to the atmosphere, Environ. Toxicol. Chem., 17, 2063-2071, 1998a.

Leonard, T. L., Taylor, G. E., Gustin, M. S., and Fernandez, G. C. J.: Mercury and plants in contaminated soils: 2 . Environmental and physiological factors governing mercury flux to the atmosphere, Environ. Toxicol. Chem., 17, 2072-2079, 1998b.

Li, Z.-G., Feng, X., Li, P., Liang, L., Tang, S.-L., Wang, S.-F., Fu, X.-W., Qiu, G.-L., and Shang, L.-H.: Emissions of airborne mercury from five municipal solid waste landfills in Guiyang and Wuhan, China, Atmos. Chem. Phys., 10, 33533364, doi:10.5194/acp-10-3353-2010, 2010.

Li, Z. G., Feng, X. B., Li, G. H., Bi, X. Y., Sun, G. Y., Zhu, J. M., Qin, H. B., and Wang, J. X.: Mercury and other metal and metalloid soil contamination near a $\mathrm{Pb} / \mathrm{Zn}$ smelter in east Hunan province, China, Appl. Geochem., 26, 160-166, 2011.
Lin, C.-C., Yee, N., and Barkay, T.: Microbial Transformations in the Mercury Cycle, in: Environmental Chemistry and Toxicology of Mercury, John Wiley \& Sons, Inc., 155-191, 2011.

Lin, C.-J. and Pehkonen, S. O.: Aqueous free radical chemistry of mercury in the presence of iron oxides and ambient aerosol, Atmos. Environ., 31, 4125-4137, 1997.

Lin, C.-J., Zhu, W., Li, X., Feng, X., Sommar, J., and Shang, L.: Novel dynamic flux chamber for measuring air-surface exchange of $\mathrm{Hg}^{\circ}$ from soils, Environ. Sci. Technol., 46, 8910-8920, 2012.

Lin, C. J. and Pehkonen, S. O.: The chemistry of atmospheric mercury: a review, Atmos. Environ., 33, 2067-2079, 1999.

Lin, C. J., Gustin, M. S., Singhasuk, P., Eckley, C., and Miller, M.: Empirical models for estimating mercury flux from soils, Environ. Sci. Technol., 44, 8522-8528, 2010a.

Lin, C.-J., Pan, L., Streets, D. G., Shetty, S. K., Jang, C., Feng, X., Chu, H.-W., and Ho, T. C.: Estimating mercury emission outflow from East Asia using CMAQ-Hg, Atmos. Chem. Phys., 10, 1853-1864, doi:10.5194/acp-10-1853-2010, 2010 b.

Lindberg, S. and Meyers, T.: Development of an automated micrometeorological method for measuring the emission of mercury vapor from wetland vegetation, Wetl. Ecol. Manag., 9, 333347, 2001.

Lindberg, S. E. and Price, J. L.: Airborne Emissions of Mercury from Municipal Landfill Operations: A Short-Term Measurement Study in Florida, J. Air Waste Manage., 49, 520-532, 1999.

Lindberg, S., Meyers, T., Taylor Jr, G., Turner, R., and Schroeder, W.: Atmosphere-surface exchange of mercury in a forest: results of modeling and gradient approaches, J. Geophys. Res.-Atmos., 97, 2519-2528, 1992.

Lindberg, S., Bullock, R., Ebinghaus, R., Engstrom, D., Feng, X. B., Fitzgerald, W., Pirrone, N., Prestbo, E., and Seigneur, C.: A synthesis of progress and uncertainties in attributing the sources of mercury in deposition, Ambio, 36, 19-32, 2007.

Lindberg, S. E., Kim, K. H., Meyers, T. P., and Owens, J. G.: Micrometeorological gradient approach for quantifying air-surface exchange of mercury-vapor - tests over contaminated soils, Environ. Sci. Technol., 29, 126-135, 1995a.

Lindberg, S. E., Meyers, T. P., and Munthe, J.: Evasion of mercury vapor from the surface of a recently limed acid forest lake in Sweden, Water Air Soil Poll., 85, 725-730, 1995 b.

Lindberg, S. E., Hanson, P. J., Meyers, T. P., and Kim, K. H.: Air/surface exchange of mercury vapor over forests - The need for a reassessment of continental biogenic emissions, Atmos. Environ., 32, 895-908, 1998.

Lindberg, S. E., Zhang, H., Gustin, M., Vette, A., Marsik, F., Owens, J., Casimir, A., Ebinghaus, R., Edwards, G., Fitzgerald, C., Kemp, J., Kock, H. H., London, J., Majewski, M., Poissant, L., Pilote, M., Rasmussen, P., Schaedlich, F., Schneeberger, D., Sommar, J., Turner, R., Wallschlager, D., and Xiao, Z.: Increases in mercury emissions from desert soils in response to rainfall and irrigation, J. Geophys. Res.-Atmos., 104, 21879-21888, 1999.

Lindberg, S. E. and Zhang, H.: Air/water exchange of mercury in the Everglades II: measuring and modeling evasion of mercury from surface waters in the Everglades Nutrient Removal Project, Sci. Total Environ., 259, 135-143, 2000.

Lindberg, S. E., Brooks, S., Lin, C. J., Scott, K. J., Landis, M. S., Stevens, R. K., Goodsite, M., and Richter, A.: Dynamic oxidation of gaseous mercury in the Arctic troposphere at polar sunrise, Environ. Sci. Technol., 36, 1245-1256, 2002a. 
Lindberg, S. E., Dong, W. J., and Meyers, T.: Transpiration of gaseous elemental mercury through vegetation in a subtropical wetland in Florida, Atmos. Environ., 36, 5207-5219, 2002b.

Lindberg, S. E., Zhang, H., Vette, A. F., Gustin, M. S., Barnett, M. O., and Kuiken, T.: Dynamic flux chamber measurement of gaseous mercury emission fluxes over soils: Part 2 - effect of flushing flow rate and verification of a two-resistance exchange interface simulation model, Atmos. Environ., 36, 847$859,2002 \mathrm{c}$.

Lindberg, S. E., Southworth, G. R., Bogle, M. A., Blasing, T. J., Owens, J., Roy, K., Zhang, H., Kuiken, T., Price, J., Reinhart, D., and Sfeir, H.: Airborne emissions of mercury from municipal solid waste. I: New measurements from six operating landfills in Florida, J. Air Waste Manage., 55, 859-869, 2005.

Lindqvist, O., Johansson, K., Bringmark, L., Timm, B., Aastrup, M., Andersson, A., Hovsenius, G., Håkanson, L., Iverfeldt, ̊̊., and Meili, M.: Mercury in the Swedish environment - Recent research on causes, consequences and corrective methods, Water Air Soil Poll., 55, xi-261, doi:10.1007/BF00542429, 1991.

Liu, F., Cheng, H., Yang, K., Zhao, C., Liu, Y., Peng, M., and Li, K.: Characteristics and influencing factors of mercury exchange flux between soil and air in Guangzhou City, J. Geochem. Explor., 139, 115-121, 2014.

Lodenius, M. and Tulisalo, E.: Environmental mercury contamination around a chlor-alkali plant, B. Environ. Contam. Tox., 32, 439-444, 1984.

Loubet, B., Milford, C., Hensen, A., Daemmgen, U., Erisman, J.W., Cellier, P., and Sutton, M. A.: Advection of $\mathrm{NH}_{3}$ over a pasture field and its effect on gradient flux measurements, Biogeosciences, 6, 1295-1309, doi:10.5194/bg-6-1295-2009, 2009.

Ma, M., Wang, D., Sun, R., Shen, Y., and Huang, L.: Gaseous mercury emissions from subtropical forested and open field soils in a national nature reserve, southwest China, Atmos. Environ., 64, 116-123, 2013

Magarelli, G. and Fostier, A. H.: Influence of deforestation on the mercury air/soil exchange in the Negro River Basin, Amazon, Atmos. Environ., 39, 7518-7528, 2005.

Mann, E. A., Mallory, M. L., Ziegler, S. E., Avery, T. S., Tordon, R., and O'Driscoll, N. J.: Photoreducible mercury loss from Arctic snow is influenced by temperature and snow age, Environ. Sci. Technol., 49, 12120-12126, 2015a.

Mann, E. A., Mallory, M. L., Ziegler, S. E., Tordon, R., and O'Driscoll, N. J.: Mercury in Arctic snow: quantifying the kinetics of photochemical oxidation and reduction, Sci. Total Environ., 509, 115-132, 2015b.

Marsik, F. J., Keeler, G. J., Lindberg, S. E., and Zhang, H.: Airsurface exchange of gaseous mercury over a mixed sawgrasscattail stand within the Florida Everglades, Environ. Sci. Technol., 39, 4739-4746, 2005.

Marumoto, K. and Imai, S.: Determination of dissolved gaseous mercury in seawater of Minamata Bay and estimation for mercury exchange across air-sea interface, Mar. Chem., 168, 9-17, 2015

Mason, R. P. and Fitzgerald, W. F.: The distribution and biogeochemical cycling of mercury in the equatorial Pacific Ocean, Deep-Sea Res. Pt. I, 40, 1897-1924, 1993.

Mason, R. P. and Sullivan, K. A.: Mercury in Lake Michigan, Environ. Sci. Technol., 31, 942-947, 1997.
Mason, R. P., Fitzgerald, W. F., Hurley, J., Hanson, A. K., Donaghay, P. L., and Sieburth, J. M.: Mercury biogeochemical cycling in a stratified estuary, Limnol. Oceanogr., 38, 1227-1241, 1993.

Mason, R. P., Rolfhus, K. R., and Fitzgerald, W. F.: Mercury in the North Atlantic, Mar. Chem., 61, 37-53, 1998.

Mason, R. P., Lawson, N. M., Lawrence, A. L., Leaner, J. J., Lee, J. G., and Sheu, G.-R.: Mercury in the Chesapeake Bay, Mar. Chem., 65, 77-96, 1999.

Mason, R. P., Lawson, N. M., and Sheu, G. R.: Mercury in the Atlantic Ocean: factors controlling air-sea exchange of mercury and its distribution in the upper waters, Deep-Sea Res. Pt. II:, 48, 2829-2853, 2001.

Mason, R. P., Choi, A. L., Fitzgerald, W. F., Hammerschmidt, C. R., Lamborg, C. H., Soerensen, A. L., and Sunderland, E. M. Mercury biogeochemical cycling in the ocean and policy implications, Environ. Res., 119, 101-117, 2012.

Mauclair, C., Layshock, J., and Carpi, A.: Quantifying the effect of humic matter on the emission of mercury from artificial soil surfaces, Appl. Geochem., 23, 594-601, 2008.

Mauder, M. and Foken, T.: Documentation and instruction manual of EC Software Package TK2, 2004.

Maxwell, J. A., Holsen, T. M., and Mondal, S.: Gaseous elemental mercury (GEM) emissions from snow surfaces in Northern New York, PloS One, 8, e69342, 2013

Mazur, M., Mitchell, C. P. J., Eckley, C. S., Eggert, S. L., Kolka, R. K., Sebestyen, S. D., and Swain, E. B.: Gaseous mercury fluxes from forest soils in response to forest harvesting intensity: A field manipulation experiment, Sci. Total Environ., 496, 678-687, 2014.

Mergler, D., Anderson, H. A., Chan, L. H. M., Mahaffey, K. R., Murray, M., Sakamoto, M., and Stern, A. H.: Methylmercury exposure and health effects in humans: a worldwide concern, AMBIO, 36, 3-11, 2007.

Millhollen, A. G., Gustin, M. S., and Obrist, D.: Foliar mercury accumulation and exchange for three tree species, Environ. Sci. Technol., 40, 6001-6006, 2006 a.

Millhollen, A. G., Obrist, D., and Gustin, M. S.: Mercury accumulation in grass and forb species as a function of atmospheric carbon dioxide concentrations and mercury exposures in air and soil, Chemosphere, 65, 889-897, 2006b.

Moncrieff, J. B., Beverland, I. J., ÓNéill, D. H., and Cropley, F. D.: Controls on trace gas exchange observed by a conditional sampling method, Atmos. Environ., 32, 3265-3274, 1998.

Moore, C. and Carpi, A.: Mechanisms of the emission of mercury from soil: Role of UV radiation, J. Geophys. Res.-Atmos., 110, D24302, doi:10.1029/2004JD005567, 2005.

Moore, C. W., Obrist, D., Steffen, A., Staebler, R. M., Douglas, T. A., Richter, A., and Nghiem, S. V.: Convective forcing of mercury and ozone in the Arctic boundary layer induced by leads in sea ice, Nature, 506, 81-84, 2014.

Moreno, F., Anderson, C. N., Stewart, R., Robinson, B., Nomura, R., Ghomshei, M., and Meech, J. A.: Effect of thioligands on plant-Hg accumulation and volatilisation from mercurycontaminated mine tailings, Plant Soil, 275, 233-246, 2005a.

Moreno, F. N., Anderson, C. W. N., Stewart, R. B., Robinson, B. H., Ghomshei, M., and Meech, J. A.: Induced plant uptake and transport of mercury in the presence of sulphur-containing ligands and humic acid, New Phytol., 166, 445-454, 2005 b. 
Nacht, D. M. and Gustin, M. S.: Mercury emissions from background and altered geologic units throughout Nevada, Water Air Soil Poll., 151, 179-193, 2004.

Nacht, D. M., Gustin, M. S., Engle, M. A., Zehner, R. E., and Giglini, A. D.: Atmospheric mercury emissions and speciation at the sulphur bank mercury mine superfund site, Northern California, Environ. Sci. Technol., 38, 1977-1983, 2004.

Narukawa, M., Sakata, M., Marumoto, K., and Asakura, K.: Air-sea exchange of mercury in Tokyo Bay, J. Oceanogr., 62, 249-257, 2006.

Nemitz, E., Flynn, M., Williams, P., Milford, C., Theobald, M., Blatter, A., Gallagher, M., and Sutton, M.: A relaxed eddy accumulation system for the automated measurement of atmospheric ammonia fluxes, Water Air Soil Poll., 1, 189-202, 2001.

Nguyen, H. T., Kim, K. H., Kim, M. Y., and Shon, Z. H.: Exchange pattern of gaseous elemental mercury in an active urban landfill facility, Chemosphere, 70, 821-832, 2008.

Niu, Z. C., Zhang, X. S., Wang, Z. W., and Ci, Z. J.: Field controlled experiments of mercury accumulation in crops from air and soil, Environ. Poll., 159, 2684-2689, 2011.

O’Driscoll, N. J., Beauchamp, S., Siciliano, S. D., Rencz, A. N., and Lean, D. R. S.: Continuous analysis of dissolved gaseous mercury (DGM) and mercury flux in two freshwater lakes in Kejimkujik Park, Nova Scotia: Evaluating mercury flux models with quantitative data, Environ. Sci. Technol., 37, 2226-2235, 2003.

O’Driscoll, N. J., Siciliano, S. D., Lean, D. R. S., and Amyot, M.: Gross photoreduction kinetics of mercury in temperate freshwater lakes and rivers: Application to a general model of DGM dynamics, Environ. Sci. Technol., 40, 837-843, 2006.

O'Driscoll, N. J., Poissant, L., Canario, J., Ridal, J., and Lean, D. R. S.: Continuous analysis of dissolved gaseous mercury and mercury volatilization in the upper St. Lawrence River: Exploring temporal relationships and UV attenuation, Environ. Sci. Technol., 41, 5342-5348, 2007.

O'Driscoll, N. J., Poissant, L., Canario, J., and Lean, D. R. S.: Dissolved gaseous mercury concentrations and mercury volatilization in a frozen freshwater fluvial lake, Environ. Sci. Technol., 42, 5125-5130, 2008.

Obrist, D.: Atmospheric mercury pollution due to losses of terrestrial carbon pools?, Biogeochemistry, 85, 119-123, 2007.

Obrist, D., Gustin, M. S., Arnone, J. A., Johnson, D. W., Schorran, D. E., and Verburg, P. S. J.: Measurements of gaseous elemental mercury fluxes over intact tallgrass prairie monoliths during one full year, Atmos. Environ., 39, 957-965, 2005.

Obrist, D., Conen, F., Vogt, R., Siegwolf, R., and Alewell, C.: Estimation of $\mathrm{Hg}^{0}$ exchange between ecosystems and the atmosphere using ${ }^{222} \mathrm{Rn}$ and $\mathrm{Hg}^{0}$ concentration changes in the stable nocturnal boundary layer, Atmos. Environ., 40, 856-866, 2006.

Obrist, D., Johnson, D. W., Lindberg, S. E., Luo, Y., Hararuk, O., Bracho, R., Battles, J. J., Dail, D. B., Edmonds, R. L., Monson, R. K., Ollinger, S. V., Pallardy, S. G., Pregitzer, K. S., and Todd, D. E.: Mercury distribution across 14 U.S. forests. Part I: spatial patterns of concentrations in biomass, litter, and soils, Environ. Sci. Technol., 45, 3974-3981, 2011.

Olofsson, M., Sommar, J., Ljungström, E., Andersson, M., and Wängberg, I.: Application of relaxed eddy accumulation technique to quantify $\mathrm{Hg}^{0}$ fluxes over modified soil surfaces, Water Air Soil Poll., 167, 331-352, 2005.
Osterwalder, S., Fritsche, J., Alewell, C., Schmutz, M., Nilsson, M. B., Jocher, G., Sommar, J., Rinne, J., and Bishop, K.: A dualinlet, single detector relaxed eddy accumulation system for longterm measurement of mercury flux, Atmos. Meas. Tech., 9, 509524, doi:10.5194/amt-9-509-2016, 2016.

Pacyna, E. G., Pacyna, J. M., Fudala, J., Strzelecka-Jastrzab, E., Hlawiczka, S., and Panasiuk, D.: Mercury emissions to the atmosphere from anthropogenic sources in Europe in 2000 and their scenarios until 2020, Sci. Total Environ., 370, 147-156, 2006.

Pannu, R., Siciliano, S. D., and O'Driscoll, N. J.: Quantifying the effects of soil temperature, moisture and sterilization on elemental mercury formation in boreal soils, Environ. Poll., 193, 138-146, 2014.

Pierce, A., Obrist, D., Moosmüller, H., Faïn, X., and Moore, C.: Cavity ring-down spectroscopy sensor development for high-time-resolution measurements of gaseous elemental mercury in ambient air, Atmos. Meas. Tech., 6, 1477-1489, doi:10.5194/amt-6-1477-2013, 2013.

Pierce, A. M., Moore, C. W., Wohlfahrt, G., Hörtnagl, L., Kljun, N., and Obrist, D.: Eddy covariance flux measurements of gaseous elemental mercury using cavity ring-down spectroscopy, Environ. Sci. Technol., 49, 1559-1568, 2015.

Pirrone, N., Cinnirella, S., Feng, X., Finkelman, R. B., Friedli, H. R., Leaner, J., Mason, R., Mukherjee, A. B., Stracher, G. B., Streets, D. G., and Telmer, K.: Global mercury emissions to the atmosphere from anthropogenic and natural sources, Atmos. Chem. Phys., 10, 5951-5964, doi:10.5194/acp-10-59512010, 2010.

Poissant, L. and Casimir, A.: Water-air and soil-air exchange rate of total gaseous mercury measured at background sites, Atmos. Environ., 32, 883-893, 1998.

Poissant, L., Pilote, M., and Casimir, A.: Mercury flux measurements in a naturally enriched area: Correlation with environmental conditions during the Nevada Study and Tests of the Release of Mercury From Soils (STORMS), J. Geophys. Res.-Atmos., 104, 21845-21857, 1999.

Poissant, L., Amyot, M., Pilote, M., and Lean, D.: Mercury waterair exchange over the Upper St. Lawrence River and Lake Ontario, Environ. Sci. Technol., 34, 3069-3078, 2000.

Poissant, L., Pilote, M., Constant, P., Beauvais, C., Zhang, H. H., and $\mathrm{Xu}, \mathrm{X}$.: Mercury gas exchanges over selected bare soil and flooded sites in the bay St. Francois wetlands (Quebec, Canada), Atmos. Environ., 38, 4205-4214, 2004a.

Poissant, L., Pilote, M., Xu, X. H., Zhang, H., and Beauvais, C.: Atmospheric mercury speciation and deposition in the Bay St. Francois wetlands, J. Geophys. Res.-Atmos., 109, D11301, doi:10.1029/2003JD004364, 2004b.

Poissant, L., Pilote, M., Yumvihoze, E., and Lean, D.: Mercury concentrations and foliage/atmosphere fluxes in a maple forest ecosystem in Quebec, Canada, J. Geophys. Res.-Atmos., 113, D10307, doi:10.1029/2007JD009510, 2008.

Poulain, A. J., Lalonde, J. D., Amyot, M., Shead, J. A., Raofie, F., and Ariya, P. A.: Redox transformations of mercury in an Arctic snowpack at springtime, Atmos. Environ., 38, 6763-6774, 2004.

Poulain, A. J., Roy, V., and Amyot, M.: Influence of temperate mixed and deciduous tree covers on $\mathrm{Hg}$ concentrations and photoredox transformations in snow, Geochim. Cosmochim. Ac., 71, 2448-2462, 2007. 
Quinones, J. L. and Carpi, A.: An Investigation of the kinetic processes influencing mercury emissions from sand and soil samples of varying thickness, J. Environ. Qual., 40, 647-652, 2011.

Qureshi, A., O’Driscoll, N. J., MacLeod, M., Neuhold, Y. M., and Hungerbuhler, K.: Photoreactions of mercury in surface ocean water: gross reaction kinetics and possible pathways, Environ. Sci. Technol., 44, 644-649, 2010.

Qureshi, A., MacLeod, M., and Hungerbuhler, K.: Quantifying uncertainties in the global mass balance of mercury, Global Biogeochem. Cy., 25, GB4012, doi:10.1029/2011gb004068, 2011a.

Qureshi, A., MacLeod, M., Sunderland, E., and Hungerbühler, K.: Exchange of elemental mercury between the oceans and the atmosphere, in: Environmental Chemistry and Toxicology of Mercury, edited by: Liu, G. L., Cai, Y., and O'Driscoll, N., John Wiley \& Sons, Inc: Hoboken, NJ, 389-421, 2011 b.

Ravichandran, M.: Interactions between mercury and dissolved organic matter - a review, Chemosphere, 55, 319-331, 2004.

Rea, A. W., Lindberg, S. E., Scherbatskoy, T., and Keeler, G. J.: Mercury accumulation in foliage over time in two northern mixed-hardwood forests, Water Air Soil Poll., 133, 49-67, 2002.

Rinklebe, J., During, A., Overesch, M., Wennrich, R., Stark, H. J., Mothes, S., and Neue, H. U.: Optimization of a simple field method to determine mercury volatilization from soils-Examples of 13 sites in floodplain ecosystems at the Elbe River (Germany), Ecol. Eng., 35, 319-328, 2009.

Rolfhus, K. R. and Fitzgerald, W. F.: The evasion and spatial/temporal distribution of mercury species in Long Island Sound, CT-NY, Geochim. Cosmochim. Ac., 65, 407-418, 2001.

Rutter, A. P., Schauer, J. J., Shafer, M. M., Creswell, J., Olson, M. R., Clary, A., Robinson, M., Parman, A. M., and Katzman, T. L.: Climate Sensitivity of Gaseous Elemental Mercury Dry Deposition to Plants: Impacts of Temperature, Light Intensity, and Plant Species, Environ. Sci. Technol., 45, 569-575, 2011 a.

Rutter, A. P., Schauer, J. J., Shafer, M. M., Creswell, J. E., Olson, M. R., Robinson, M., Collins, R. M., Parman, A. M., Katzman, T. L., and Mallek, J. L.: Dry deposition of gaseous elemental mercury to plants and soils using mercury stable isotopes in a controlled environment, Atmos. Environ., 45, 848-855, 2011 b.

Scholtz, M. T., Van Heyst, B. J., and Schroeder, W.: Modelling of mercury emissions from background soils, Sci. Total Environ., 304, 185-207, 2003.

Schroeder, W., Lindqvist, O., Munthe, J., and Xiao, Z. F.: Volatilization of mercury from lake surfaces, Sci. Total Environ., 125, 4766, 1992.

Schroeder, W., Anlauf, K., Barrie, L., Lu, J., Steffen, A., Schneeberger, D., and Berg, T.: Arctic springtime depletion of mercury, Nature, 394, 331-332, 1998.

Schroeder, W. H., Munthe, J., and Lindqvist, O.: Cycling of mercury between water, air, and soil compartments of the environment, Water Air Soil Poll., 48, 337-347, 1989.

Schroeder, W. H., Steffen, A., Scott, K., Bender, T., Prestbo, E., Ebinghaus, R., Lu, J. Y., and Lindberg, S. E.: Summary report: first international Arctic atmospheric mercury research workshop, Atmos. Environ., 37, 2551-2555, 2003.

Schroeder, W. H., Beauchamp, S., Edwards, G., Poissant, L., Rasmussen, P., Tordon, R., Dias, G., Kemp, J., Van Heyst, B., and Banic, C. M.: Gaseous mercury emissions from natural sources in Canadian landscapes, J. Geophys. Res.-Atmos., 110, D18302, doi:10.1029/2004JD005699, 2005.
Selin, N. E.: Global Biogeochemical Cycling of Mercury: A Review, Annu. Rev. Env. Resour., 34, 43-63, 2009.

Selin, N. E., Jacob, D. J., Park, R. J., Yantosca, R. M., Strode, S., Jaegle, L., and Jaffe, D.: Chemical cycling and deposition of atmospheric mercury: Global constraints from observations, J. Geophys. Res.-Atmos., 112, D02308, doi:10.1029/2006JD007450, 2007.

Selin, N. E., Jacob, D. J., Yantosca, R. M., Strode, S., Jaegle, L., and Sunderland, E. M.: Global 3-D land-ocean-atmosphere model for mercury: Present-day versus preindustrial cycles and anthropogenic enrichment factors for deposition, Global Biogeochem. Cy., 22, GB2011, doi:10.1029/2007GB003040, 2008.

Sherman, L. S., Blum, J. D., Johnson, K. P., Keeler, G. J., Barres, J. A., and Douglas, T. A.: Mass-independent fractionation of mercury isotopes in Arctic snow driven by sunlight, Nat. Geosci., 3, 173-177, 2010.

Shetty, S. K., Lin, C. J., Streets, D. G., and Jang, C.: Model estimate of mercury emission from natural sources in East Asia, Atmos. Environ., 42, 8674-8685, 2008.

Si, L. and Ariya, P. A.: Photochemical reactions of divalent mercury with thioglycolic acid: Formation of mercuric sulfide particles, Chemosphere, 119, 467-472, 2015.

Siciliano, S. D., O'Driscoll, N. J., and Lean, D. R. S.: Microbial Reduction and Oxidation of Mercury in Freshwater Lakes, Environ Sci. Technol., 36, 3064-3068, 2002.

Sigler, J. M. and Lee, X.: Gaseous mercury in background forest soil in the northeastern United States, J. Geophys. Res.-Atmos., 111, G02007, doi:10.1029/2005JG000106, 2006.

Sjöholm, M., Weibring, P., Edner, H., and Svanberg, S.: Atomic mercury flux monitoring using an optical parametric oscillator based lidar system, Opt. Express, 12, 551-556, 2004.

Skyllberg, U., Bloom, P. R., Qian, J., Lin, C. M., and Bleam, W. F.: Complexation of mercury(II) in soil organic matter: EXAFS evidence for linear two-coordination with reduced sulfur groups, Environ. Sci. Technol., 40, 4174-4180, 2006.

Slemr, F., Seiler, W., Eberling, C., and Roggendorf, P.: The determination of total gaseous mercury in air at background levels, Anal. Chim. Acta, 110, 35-47, 1979.

Slemr, F., Brunke, E.-G., Whittlestone, S., Zahorowski, W., Ebinghaus, R., Kock, H. H., and Labuschagne, C.: ${ }^{222}$ Rn-calibrated mercury fluxes from terrestrial surface of southern Africa, Atmos. Chem. Phys., 13, 6421-6428, doi:10.5194/acp-13-64212013, 2013.

Smith-Downey, N. V., Sunderland, E. M., and Jacob, D. J.: Anthropogenic impacts on global storage and emissions of mercury from terrestrial soils: Insights from a new global model, J. Geophys. Res.-Biogeo., 115, G03008, doi:10.1029/2009JG001124, 2010.

Smith, L. M. and Reinfelder, J. R.: Mercury volatilization from salt marsh sediments, J. Geophys. Res.-Biogeo., 114, G00C09, doi:10.1029/2009JG000979, 2009.

Soerensen, A. L., Sunderland, E. M., Holmes, C. D., Jacob, D. J., Yantosca, R. M., Skov, H., Christensen, J. H., Strode, S. A., and Mason, R. P.: An improved global model for air-sea exchange of mercury: high concentrations over the North Atlantic, Environ. Sci. Technol., 44, 8574-8580, 2010.

Sommar, J., Wängberg, I., Berg, T., Gårdfeldt, K., Munthe, J., Richter, A., Urba, A., Wittrock, F., and Schroeder, W. H.: Circumpolar transport and air-surface exchange of atmospheric mer- 
cury at Ny-Ålesund $\left(79^{\circ} \mathrm{N}\right)$, Svalbard, spring 2002, Atmos. Chem. Phys., 7, 151-166, doi:10.5194/acp-7-151-2007, 2007.

Sommar, J., Zhu, W., Lin, C.-J., and Feng, X.: Field approaches to measure $\mathrm{Hg}$ exchange between natural surfaces and the atmosphere - a review, Crit. Rev. Env. Sci. Tec., 43, 1657-1739, 2013a.

Sommar, J., Zhu, W., Shang, L., Feng, X., and Lin, C.-J.: A wholeair relaxed eddy accumulation measurement system for sampling vertical vapour exchange of elemental mercury, Tellus B, 65, 19940, doi:10.3402/tellusb.v65i0.19940, 2013b.

Sommar, J., Zhu, W., Shang, L., Lin, C.-J., and Feng, X. B.: Seasonal variations in metallic mercury $\left(\mathrm{Hg}^{0}\right)$ vapor exchange over biannual wheat - corn rotation cropland in the North China Plain, Biogeosciences Discuss., 12, 16105-16158, doi:10.5194/bgd12-16105-2015, 2015.

Song, X. X. and Van Heyst, B.: Volatilization of mercury from soils in response to simulated precipitation, Atmos. Environ., 39, 7494-7505, 2005.

Southworth, G., Lindberg, S., Hintelmann, H., Amyot, M., Poulain, A., Bogle, M., Peterson, M., Rudd, J., Harris, R., Sandilands, K., Krabbenhoft, D., and Olsen, M.: Evasion of added isotopic mercury from a northern temperate lake, Environ. Toxicol. Chem., 26, 53-60, 2007.

Sprovieri, F., Pirrone, N., Ebinghaus, R., Kock, H., and Dommergue, A.: A review of worldwide atmospheric mercury measurements, Atmos. Chem. Phys., 10, 8245-8265, doi:10.5194/acp10-8245-2010, 2010.

St. Louis, V. L., Sharp, M. J., Steffen, A., May, A., Barker, J., Kirk, J. L., Kelly, D. J. A., Arnott, S. E., Keatley, B., and Smol, J. P.: Some sources and sinks of monomethyl and inorganic mercury on Ellesmere Island in the Canadian high Arctic, Environ. Sci. Technol., 39, 2686-2701, 2005.

Stamenkovic, J. and Gustin, M. S.: Evaluation of use of EcoCELL technology for quantifying total gaseous mercury fluxes over background substrates, Atmos. Environ., 41, 3702-3712, 2007.

Stamenkovic, J., Gustin, M. S., Arnone, J. A., Johnson, D. W., Larsen, J. D., and Verburg, P. S. J.: Atmospheric mercury exchange with a tallgrass prairie ecosystem housed in mesocosms, Sci. Total Environ., 406, 227-238, 2008.

Stamenkovic, J. and Gustin, M. S.: Nonstomatal versus stomatal uptake of atmospheric mercury, Environ. Sci. Technol., 43, 13671372, 2009.

Steen, A. O., Berg, T., Dastoor, A. P., Durnford, D. A., Hole, L. R., and Pfaffhuber, K. A.: Dynamic exchange of gaseous elemental mercury during polar night and day, Atmos. Environ., 43, 56045610, 2009.

Steffen, A., Douglas, T., Amyot, M., Ariya, P., Aspmo, K., Berg, T., Bottenheim, J., Brooks, S., Cobbett, F., Dastoor, A., Dommergue, A., Ebinghaus, R., Ferrari, C., Gardfeldt, K., Goodsite, M. E., Lean, D., Poulain, A. J., Scherz, C., Skov, H., Sommar, J., and Temme, C.: A synthesis of atmospheric mercury depletion event chemistry in the atmosphere and snow, Atmos. Chem. Phys., 8, 1445-1482, doi:10.5194/acp-8-1445-2008, 2008.

Steffen, A., Bottenheim, J., Cole, A., Douglas, T. A., Ebinghaus, R., Friess, U., Netcheva, S., Nghiem, S., Sihler, H., and Staebler, R.: Atmospheric mercury over sea ice during the OASIS-2009 campaign, Atmos. Chem. Phys., 13, 7007-7021, doi:10.5194/acp-137007-2013, 2013.
Strode, S. A., Jaegle, L., Selin, N. E., Jacob, D. J., Park, R. J., Yantosca, R. M., Mason, R. P., and Slemr, F.: Air-sea exchange in the global mercury cycle, Global Biogeochem. Cy., 21, GB1017, doi:10.1029/2006GB002766, 2007.

Sun, R., Wang, D., Mao, W., Zhao, S., and Zhang, C.: Roles of chloride ion in photo-reduction/oxidation of mercury, Chinese Sci. Bull., 59, 3390-3397, 2014.

Sutton, M. A., Nemitz, E., Erisman, J. W., Beier, C., Bahl, K. B., Cellier, P., de Vries, W., Cotrufo, F., Skiba, U., Di Marco, C., Jones, S., Laville, P., Soussana, J. F., Loubet, B., Twigg, M., Famulari, D., Whitehead, J., Gallagher, M. W., Neftel, A., Flechard, C. R., Herrmann, B., Calanca, P. L., Schjoerring, J. K., Daemmgen, U., Horvath, L., Tang, Y. S., Emmett, B. A., Tietema, A., Penuelas, J., Kesik, M., Brueggemann, N., Pilegaard, K., Vesala, T., Campbell, C. L., Olesen, J. E., Dragosits, U., Theobald, M. R., Levy, P., Mobbs, D. C., Milne, R., Viovy, N., Vuichard, N., Smith, J. U., Smith, P., Bergamaschi, P., Fowler, D., and Reis, S.: Challenges in quantifying biosphere-atmosphere exchange of nitrogen species, Environ. Pollu., 150, 125-139, 2007.

Temme, C., Baukau, J., Schneider, B., Aspmo, K., Fain, X., Ferrari, C., Gauchard, P.-A., and Ebinghaus, R.: Air/water exchange of mercury in the North Atlantic Ocean during arctic summer, Proceedings of the XIII International Conference on Heavy Metals in the Environment, Rio de Janeiro, June 2005.

Tseng, C., Lamborg, C., Fitzgerald, W., and Engstrom, D.: Cycling of dissolved elemental mercury in Arctic Alaskan lakes, Geochim. Cosmochim. Ac., 68, 1173-1184, 2004.

UNEP Minamata Convention on Mercury: available at: http://www. mercuryconvention.org (last access: 25 March 2016), 2013.

Vost, E. E., Amyot, M., and O'Driscoll, N. J.: Photoreactions of mercury in aquatic systems, in: Environmental Chemistry and Toxicology of Mercury, John Wiley \& Sons, Inc., 193-218, 2011.

Wallschläger, D., Turner, R. R., London, J., Ebinghaus, R., Kock, H. H., Sommar, J., and Xiao, Z. F.: Factors affecting the measurement of mercury emissions from soils with flux chambers, J. Geophys. Res.-Atmos., 104, 21859-21871, 1999.

Wallschläger, D., Kock, H. H., Schroeder, W. H., Lindberg, S. E., Ebinghaus, R., and Wilken, R. D.: Estimating gaseous mercury emissions from contaminated floodplain soils to the atmosphere with simple field measurement techniques, Water Air Soil Poll., 135, 39-54, 2002.

Wang, D. Y., He, L., Shi, X. J., Wei, S. Q., and Feng, X. B.: Release flux of mercury from different environmental surfaces in Chongqing, China, Chemosphere, 64, 1845-1854, 2006.

Wang, J. X., Feng, X. B., Anderson, C. W. N., Wang, H., Zheng, L. R., and Hu, T. D.: Implications of mercury speciation in thiosulfate treated plants, Environ. Sci. Technol., 46, 5361-5368, 2012.

Wang, S., Feng, X., Qiu, G., and Fu, X.: Comparison of air/soil mercury exchange between warm and cold season in Hongfeng Reservoir region, Huanjing Kexue, 25, 123-127, 2004 (in Chinese with English Abstract).

Wang, S., Feng, X., Qiu, G., Shang, L., Li, P., and Wei, Z.: Mercury concentrations and air/soil fluxes in Wuchuan mercury mining district, Guizhou province, China, Atmos. Environ., 41, 59845993, 2007a.

Wang, S. F., Feng, X. B., Qiu, G. L., Fu, X. W., and Wei, Z. Q.: Characteristics of mercury exchange flux between soil and air in the heavily air-polluted area, eastern Guizhou, China, Atmos. Environ., 41, 5584-5594, $2007 \mathrm{~b}$. 
Wang, S. F., Feng, X. B., Qiu, G. L., Wei, Z. Q., and Xiao, T. F.: Mercury emission to atmosphere from Lanmuchang $\mathrm{Hg}-\mathrm{Tl}$ mining area, Southwestern Guizhou, China, Atmos. Environ., 39, 7459-7473, 2005.

Wang, X., Lin, C.-J., and Feng, X.: Sensitivity analysis of an updated bidirectional air-surface exchange model for elemental mercury vapor, Atmos. Chem. Phys., 14, 6273-6287, doi:10.5194/acp-14-6273-2014, 2014.

Wängberg, I., Munthe, J., Pirrone, N., Iverfeldt, Å., Bahlman, E., Costa, P., Ebinghaus, R., Feng, X., Ferrara, R., and Gårdfeldt, K.: Atmospheric mercury distribution in Northern Europe and in the Mediterranean region, Atmos. Environ., 35, 3019-3025, 2001a.

Wängberg, I., Schmolke, S., Schager, P., Munthe, J., Ebinghaus, R., and Iverfeldt, A.: Estimates of air-sea exchange of mercury in the Baltic Sea, Atmos. Environ., 35, 5477-5484, 2001 b.

Wängberg, I., Edner, H., Ferrara, R., Lanzillotta, E., Munthe, J., Sommar, J., Sjöholm, M., Svanberg, S., and Weibring, P.: Atmospheric mercury near a chlor-alkali plant in Sweden, Sci. Total Environ., 304, 29-41, 2003.

Wanninkhof, R.: Relationship between wind-speed and gasexchange over the Ocean, J. Geophys. Res.-Oceans., 97, 73737382, 1992.

Wanninkhof, R., Asher, W. E., Ho, D. T., Sweeney, C., and McGillis, W. R.: Advances in quantifying air-sea gas exchange and environmental forcing, Annu. Rev. Mar. Sci., 1, 213-244, 2009.

Wesely, M. L. and Hicks, B. B.: A review of the current status of knowledge on dry deposition, Atmos. Environ., 34, 2261-2282, 2000.

Wiatrowski, H. A., Ward, P. M., and Barkay, T.: Novel reduction of mercury(II) by mercury-sensitive dissimilatory metal reducing bacteria, Environ. Sci. Technol., 40, 6690-6696, 2006.

Wright, L. P. and Zhang, L.: An approach estimating bidirectional air-surface exchange for gaseous elemental mercury at AMNet sites, J. Adv. Model. Earth Sy., 7, 35-49, 2015.

Xiao, Z. F., Munthe, J., Schroeder, W. H., and Lindqvist, O.: Vertical fluxes of volatile mercury over forest soil and lake surfaces in Sweden, Tellus B, 43, 267-279, 1991.

Xin, M., Gustin, M. S., Ladwig, K., and Pflughoeft-Hassett, D. F.: Air-substrate mercury exchange associated with landfill disposal of coal combustion products, J. Air Waste Manage., 56, 11671176,2006

Xin, M. and Gustin, M. S.: Gaseous elemental mercury exchange with low mercury containing soils: Investigation of controlling factors, Appl. Geochem., 22, 1451-1466, 2007.

Xu, L. Q., Liu, R. H., Wang, J. Y., Tan, H. W., Tang, A. K., and Yu, P.: Mercury emission flux in the Jiaozhou Bay measured by flux chamber, Procedia Environmental Sci., 13, 1500-1506, 2012.

Xu, X. H., Yang, X. S., Miller, D. R., Helble, J. J., and Carley, R. J.: Formulation of bi-directional atmosphere-surface exchanges of elemental mercury, Atmos. Environ., 33, 4345-4355, 1999.

Yamamoto, M.: Stimulation of elemental mercury oxidation in the presence of chloride ion in aquatic environments, Chemosphere, 32, 1217-1224, 1996.

Yang, Y. K., Zhang, C., Shi, X. J., Lin, T., and Wang, D. Y.: Effect of organic matter and $\mathrm{pH}$ on mercury release from soils, J. Environ. Sci., 19, 1349-1354, 2007.
Yin, R., Feng, X., and Meng, B.: Stable Hg isotope variation in rice plants (Oryza sativa L.) from the Wanshan $\mathrm{Hg}$ mining district, SW China, Environ. Sci. Technol., 47, 2238-2245, 2013.

Zehner, R. E. and Gustin, M. S.: Estimation of mercury vapor flux from natural substrate in Nevada, Environ. Sci. Technol., 36, 4039-4045, 2002.

Zhang, H.: Photochemical redox reactions of mercury, in: Recent Developments in Mercury Science, edited by: Atwood, D. A., 37-79, Springer Berlin Heidelberg, 2006.

Zhang, H. and Lindberg, S. E.: Processes influencing the emission of mercury from soils: A conceptual model, J. Geophys. Res.Atmos., 104, 21889-21896, 1999.

Zhang, H. and Lindberg, S. E.: Sunlight and iron(III)-induced photochemical production of dissolved gaseous mercury in freshwater, Environ. Sci. Technol., 35, 928-935, 2001.

Zhang, H., Lindberg, S. E., Marsik, F. J., and Keeler, G. J.: Mercury air/surface exchange kinetics of background soils of the Tahquamenon River watershed in the Michigan Upper Peninsula, Water Air Soil Poll., 126, 151-169, 2001.

Zhang, H., Lindberg, S. E., Barnett, M. O., Vette, A. F., and Gustin, M. S.: Dynamic flux chamber measurement of gaseous mercury emission fluxes over soils. Part 1: simulation of gaseous mercury emissions from soils using a two-resistance exchange interface model, Atmos. Environ., 36, 835-846, 2002.

Zhang, H., Dill, C., Kuiken, T., Ensor, M., and Crocker, W. C.: Change of dissolved gaseous mercury concentrations in a southern reservoir lake (Tennessee) following seasonal variation of solar radiation, Environ. Sci. Technol., 40, 2114-2119, 2006 a.

Zhang, H. H., Poissant, L., Xu, X. H., Pilote, M., Beauvais, C., Amyot, M., Garcia, E., and Laroulandie, J.: Air-water gas exchange of mercury in the Bay Saint Francois wetlands: Observation and model parameterization, J. Geophys. Res.-Atmos., 111, D17307, doi:10.1029/2005JD006930, 2006b.

Zhang, H., Lindberg, S. E., and Kuiken, T.: Mysterious diel cycles of mercury emission from soils held in the dark at constant temperature, Atmos. Environ., 42, 5424-5433, 2008.

Zhang, H., Feng, X., Larssen, T., Qiu, G., and Vogt, R. D.: In inland China, rice, rather than fish, is the major pathway for methylmercury exposure, Environ. Health. Persp., 118, 1183-1188, 2010.

Zhang, H. H., Poissant, L., Xu, X. H., and Pilote, M.: Explorative and innovative dynamic flux bag method development and testing for mercury air-vegetation gas exchange fluxes, Atmos. Environ., 39, 7481-7493, 2005.

Zhang, L. M., Wright, L. P., and Blanchard, P.: A review of current knowledge concerning dry deposition of atmospheric mercury, Atmos. Environ., 43, 5853-5864, 2009.

Zhang, L., Blanchard, P., Gay, D. A., Prestbo, E. M., Risch, M. R., Johnson, D., Narayan, J., Zsolway, R., Holsen, T. M., Miller, E. K., Castro, M. S., Graydon, J. A., Louis, V. L. St., and Dalziel, J.: Estimation of speciated and total mercury dry deposition at monitoring locations in eastern and central North America, Atmos. Chem. Phys., 12, 4327-4340, doi:10.5194/acp-12-43272012, 2012a.

Zhang, Y. T., Sun, R. G., Ma, M., and Wang, D. Y.: Study of inhibition mechanism of $\mathrm{NO}_{3}^{-}$on photoreduction of $\mathrm{Hg}(\mathrm{II})$ in artificial water, Chemosphere, 87, 171-176, $2012 \mathrm{~b}$.

Zhang, Y. T., Chen, X., Yang, Y. K., Wang, D. Y., and Liu, X.: Effect of dissolved organic matter on mercury release from water body, J. Environ. Sci., 23, 912-917, 2011. 
Zheng, N., Liu, J. S., Wang, Q. C., and Liang, Z. Z.: Mercury contamination due to zinc smelting and chlor-alkali production in NE China, Appl. Geochem., 26, 188-193, 2011.

Zheng, W. and Hintelmann, H.: Isotope fractionation of mercury during its photochemical reduction by low-molecular-weight organic compounds, J. Phys. Chem. A, 114, 4246-4253, 2010.

Zheng, W., Liang, L. Y., and Gu, B. H.: Mercury reduction and oxidation by reduced natural organic matter in anoxic environments, Environ. Sci. Technol., 46, 292-299, 2012.

Zheng, W., Lin, H., Mann, B. F., Liang, L., and Gu, B.: Oxidation of dissolved elemental mercury by thiol compounds under anoxic conditions, Environ. Sci. Technol., 47, 12827-12834, 2013.

Zhu, J. S., Wang, D. Y., Liu, X. A., and Zhang, Y. T.: Mercury fluxes from air/surface interfaces in paddy field and dry land, Appl. Geochem., 26, 249-255, 2011.

Zhu, J. S., Wang, D. Y., and Ma, M.: Mercury release flux and its influencing factors at the air-water interface in paddy field in Chongqing, China, Chinese Sci. Bull., 58, 266-274, 2013 a.
Zhu, W., Li, Z., Chai, X., Hao, Y., Lin, C.-J., Sommar, J., and Feng, $\mathrm{X}$.: Emission characteristics and air-surface exchange of gaseous mercury at the largest active landfill in Asia, Atmos. Environ., 79, 188-197, 2013b.

Zhu, W., Sommar, J., Li, Z., Feng, X., Lin, C.-J., and Li, G.: Highly elevated emission of mercury vapor due to the spontaneous combustion of refuse in a landfill, Atmos. Environ., 79, 540-545, 2013c.

Zhu, W., Sommar, J., Lin, C.-J., and Feng, X.: Mercury vapor airsurface exchange measured by collocated micrometeorological and enclosure methods - Part II: Bias and uncertainty analysis, Atmos. Chem. Phys., 15, 5359-5376, doi:10.5194/acp-15-53592015, 2015a.

Zhu, W., Sommar, J., Lin, C.-J., and Feng, X.: Mercury vapor air-surface exchange measured by collocated micrometeorological and enclosure methods - Part I: Data comparability and method characteristics, Atmos. Chem. Phys., 15, 685-702, doi:10.5194/acp-15-685-2015, 2015 b. 